Comprehensive review of the basic chemical behaviours, sources, processes, and endpoints of trace element contamination in paddy soil-rice systems in rice-growing

\title{
countries
}

Waqar Ali a, b, Kang Mao ${ }^{\text {a }}$, Hua Zhang ${ }^{a^{*}}$, Muhammad Junaid ${ }^{\mathrm{c}}$, Nan Xu ${ }^{\mathrm{c}}$, Atta Rasool ${ }^{\mathrm{e}}$, Xinbin Feng a and Zhugen Yang ${ }^{\mathrm{d}}$

a State Key Laboratory of Environmental Geochemistry, Institute of Geochemistry, Chinese Academy of Sciences, Guiyang 550081, China.

${ }^{\text {b }}$ University of Chinese Academy of Sciences, Beijing 100049, China.

c Key Laboratory for Heavy Metal Pollution Control and Reutilization, School of Environment and Energy, Peking University Shenzhen Graduate School, Shenzhen 518055, China.

${ }^{\mathrm{d}}$ Cranfield Water Science Institute, Cranfield University, Cranfield, MK43 0AL, United Kingdom.

e Department of Environmental Sciences COMSATS University, Islamabad Vehari Campus, Vehari 61100. Pakistan.

\section{*Corresponding author}

Prof. Hua Zhang

Email: zhanghua@mail.gyig.ac.cn 


\begin{abstract}
Rice is the leading staple food for more than half of the world's population, and approximately 160 million hectares of agricultural area worldwide are under rice cultivation. Therefore, it is essential to fulfil the global demand for rice while maintaining food safety. Rice acts as a sink for potentially toxic metals such as arsenic (As), selenium ( $\mathrm{Se})$, cadmium $(\mathrm{Cd})$, lead $(\mathrm{Pb})$, zinc $(\mathrm{Zn})$, manganese $(\mathrm{Mn})$, nickel $(\mathrm{Ni})$, and chromium $(\mathrm{Cr})$ in paddy soil-rice systems due to the natural and anthropogenic sources of these metals that have developed in the last few decades. This review summarizes the sources and basic chemical behaviours of these trace elements in the soil system and their contamination status, uptake, translocation, and accumulation mechanisms in paddy soil-rice systems in major rice-growing countries. Several human health threats are significantly associated with these toxic and potentially toxic metals not only due to their presence in the environment (i.e., the soil, water, and air) but also due to the uptake and translocation of these metals via different transporters. Elevated concentrations of these metals are toxic to plants, animals, and even humans that consume them regularly, and the uniform deposition of metals causes a severe risk of bioaccumulation. Furthermore, the contamination of rice in the global rice trade makes this a critical problem of worldwide concern. Therefore, the global consumption of contaminated rice causes severe human health effects that require rapid action. Finally, this review also summarizes the available management/remediation measures and future research directions for addressing this critical issue.
\end{abstract}

Keywords: Trace metal contaminants; Paddy soil system; Health effects; Transportation mechanisms; Accumulation 


\section{Contents}

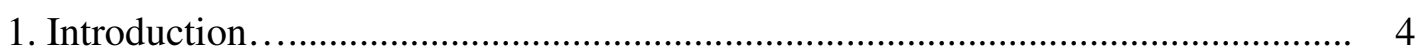

2. Trace element contamination in soil: Possible sources...................................... 6

2.1. Natural sources.................................................................................... 6

2.2. Anthropogenic sources.................................................................... 7

2.2.1. Agricultural activities ............................................................................ 7

2.2.2. Industrial activities ............................................................................. 12

3. Trace element basic chemistry, behaviour in the soil system, and associated 14

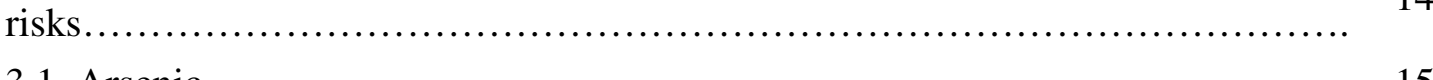

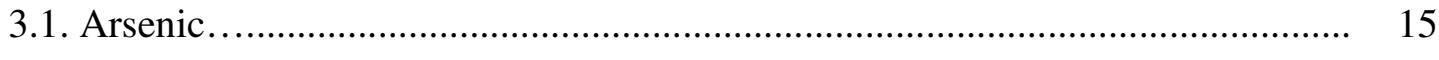

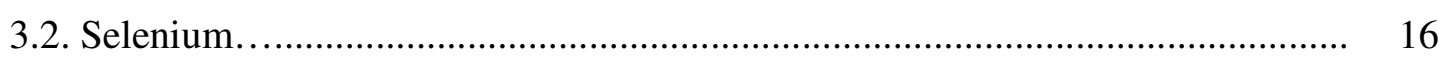

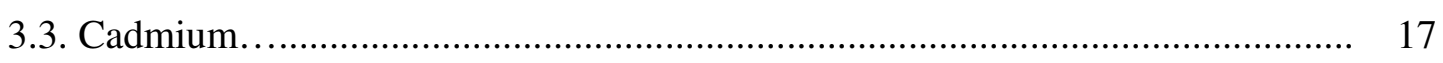

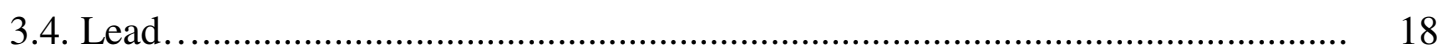

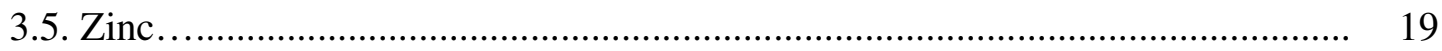

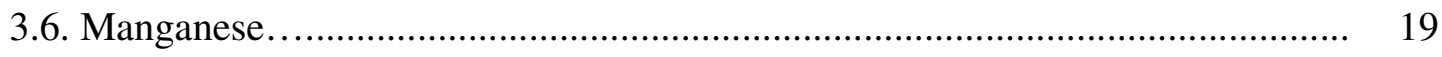

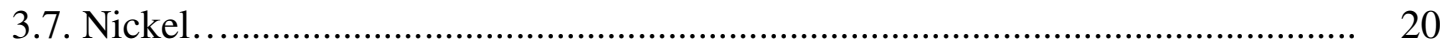

3.8. Chromium..................................................... 22

4. Mechanisms of trace element uptake, translocation, and accumulation in paddy soil-rice systems...................................................... 23

5. Status of trace element contamination in paddy soil-rice systems and risks to ricegrowing countries.

6. Trace element accumulation influences in paddy soil-rice system...................... 32

7. Trace element-contaminated soil management/remediation methods............. 34

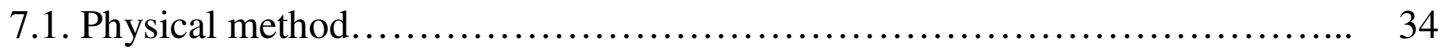

7.2. Chemical method.................................................. 35

7.3. Phytoremediation............................................... 36

7.4. Microbial remediation................................................ 39

8. Conclusion and future research perspectives.............................. 40

9. Acknowledgment..................................................................................... 41

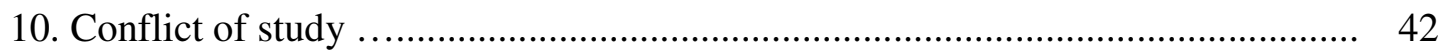

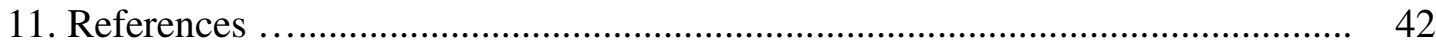




\section{Introduction}

The word "paddy" is taken from the Malay word "padi," which means "rice plant"; paddy soil, a well-known soil type, is submerged during rice cultivation [1]. Trace metal contamination in paddy soil-rice systems poses a severe threat to the production of safe rice crops worldwide [2]. Trace element contamination in terrestrial resources is a focus of various environmental studies and requires more attention worldwide due to the toxicity, persistence, and bioaccumulation of these elements [3, 4]. Agricultural soil has been contaminated by untreated waste discharge, emissions from rapidly intensifying industrial areas, increasing mining activities, chemical fertilizer use, industrial effluent disposal practices, and domestic wastewater [5]. Trace metals such as As, $\mathrm{Se}, \mathrm{Cd}, \mathrm{Pb}, \mathrm{Zn}, \mathrm{Mn}, \mathrm{Ni}$, and $\mathrm{Cr}$ constitute an imprecisely defined group of inorganic biochemical hazards that are mainly found at polluted sites $[6,7]$. Soils are a substantial sink for trace metals released in unconfined environmental matrices due to human activities. Unlike organic pollutants, trace metals are not oxidizable to carbon dioxide $\left(\mathrm{CO}_{2}\right)$ through microbial action. Trace metals do not undergo biochemical degradation [8], and they persist in the soil system for a long time once they are released into the environment [9]. The presence of trace metals in paddy-soil systems can severely constrain the biodegradation of organic pollutants [10].

The excessive concentrations of trace elements in agricultural soil systems result in increased trace element uptake by food crops such as paddy rice, wheat, maize, and vegetables [11]. Trace element contamination in paddy soil-rice systems poses severe a threat to the human population as well as to ecosystems via direct ingestion or interaction with polluted soils and contaminated water; these contaminants become a part of food chains, such as the paddy soil-rice-human and paddy soil-rice plant-animal-human food chains. The rapid increase in the human population has led to a decrease in food quality and food safety due to the attenuation of agricultural lands, which has triggered food uncertainty and agricultural land occupancy problems [10]. Unpolluted agricultural areas are polluted with trace metals from polluted water that comes directly from cities or from other anthropogenic sources and is used for irrigation purposes; the constant use of agrochemicals and fertilizers is another source of trace metals $[12,13]$. Such paddy soils expose humans to a high level of trace elements, and children are at a significantly higher health risk than adults according to risk assessment indices [11]. 
Paddy cultivation in this respect is of extreme concern since crops need a very high quantity of irrigated water from seed growth to crop harvesting [14]. Approximately 160 million hectares of the global agricultural area is under rice cultivation, and rice is the leading staple food for more than half of the world's population [15]. The category of total agrarian land includes paddy rice cultivation, and the average paddy rice production has progressively increased from 1.8 metric tons/hectare in 1960 to 4.3 metric tons/hectare currently [2]. Over the last few decades, rice consumption has increased, which has made it a valuable product [16]. Approximately $92 \%$ of the total world paddy rice is produced in Asia, and paddy rice is a well-known staple food consumed by most of the world's population [17]. Trace metal pollution in the paddy-soil system and its successive accumulation in different parts of the rice plant (roots, shoots, leaves, and grains) have been observed in different rice-growing countries [18]. Hence, trace metal contamination in paddy soils and its transfer in paddy soil-rice systems are a growing concern [19]. Several studies in various countries have investigated certain specific trace elements, such as As, $\mathrm{Se}, \mathrm{Cd}, \mathrm{Pb}, \mathrm{Zn}, \mathrm{Mn}, \mathrm{Ni}$, and $\mathrm{Cr}[11]$.

Currently, measuring or predicting the likely human health risks of trace elements that primarily originate from exposure to metal-polluted soil, water, and atmospheric deposition is becoming more common [20]. These trace elements are mainly studied in works evaluating the potentially toxic trace elements through human health risk assessments specifically targeting children and male and female adults [21]. The human health risks of metal-polluted soils can be measured by using the soil pollution indices of trace elements, soil to plant transfer factors, and their concentrations in rice systems [20, 22]. Recent studies have stated that trace element accumulation in paddy soil systems is related to risks to soil fertility and quality, as well as soil biochemical activity such as microbial and enzyme activity. Elevated trace element concentrations in paddy soil systems are primarily known to affect the microbial count in soil and the associated microbial activities, which directly influence the fertility of the soil [23]. Furthermore, the public is becoming more conscious of the implications of trace element contamination in agricultural soils and its severe toxic effects on human and environmental health as well as of the enhancement and expansion of technologies for trace element removal/clean-up at polluted sites [24]. Hence, it is imperative to deploy recent advances and various site-specific contamination clean-up 
technologies that might feasibly and effectively remediate trace element pollution in soils. In addition, a summary of recent review papers about trace element contamination in soilplant and rice system topics, objectives and gaps is discussed in Table S1.

The present study aims to systematically review and understand the basic behaviours of trace metals in the soil system to assess sources, uptake, translocation and accumulation mechanisms, the status of trace element contamination, and associated risks in paddy soilrice systems in rice-growing countries and contaminated soil management/remediation methods.

\section{Trace element contamination in soil: Possible sources}

\subsection{Natural sources}

Trace metals persist naturally in the soil environment mainly due to pedogenic processes of parent material weathering at a concentration that is regarded as trace $(<1000 \mathrm{mg} / \mathrm{kg})$ and are infrequently poisonous [10]. It is deceptive that the significant preliminary source of trace metals in the soil system is the parent material [25]. The effect of parent materials in defining the trace element content is notable in soil systems, which have formed from the same or an individual parent material, such as igneous rocks, sedimentary rocks, and/or new soils weathered under temperate environments [26]. As soon as the rock weathering process takes place, the main crystal-like structures of the raw materials are entirely broken down and allow trace metals to either be adsorbed on the soil surface or transported to the surface or groundwater system [2]. The effect of rock parent materials on the type and content of trace elements in the soil system are mainly reliant on pedogenic processes [27]. However, trace metal concentrations in soil systems are primarily derived from pedogenic parent materials, and the physicochemical and biological features of soil determine the extent of trace element accumulation [28]. Hence, trace element contamination in the soil system primarily results from the natural availability of extensive parent material (glacial till), and anthropogenic activities are also significant sources [29].

Accordingly, uncovering a strong association between trace element status in the soil system and the parent material is demanding [30]. According to [31, 32], a compilation of results from the monitoring of significant sources of trace elements in paddy soil and a pollution assessment of the Yangtze River Delta and Fuyang County in China, respectively, suggested that the Ni concentration of the paddy-soil system was determined to be high 
due to the parent material and that Ni showed the most extreme high concentration of all contaminants.

Another study from Dongguan, China, described the status of trace element levels in agricultural soils and in different vegetables with diverse key sources. $\mathrm{Cu}, \mathrm{Zn}, \mathrm{Ni}, \mathrm{Cr}$, and As, were mainly derived from natural rock parent materials. Nevertheless, $\mathrm{Cd}$ and $\mathrm{Pb}$ were present due to anthropogenic activities and were above the recommended concentrations of trace metals in soil systems; this was not true of the parent material [33].

The critical relationship between mafic rock types and levels of trace elements such as $\mathrm{Ni}, \mathrm{Al}, \mathrm{Mn}, \mathrm{Mg}$, and $\mathrm{V}$ in the soil system suggests the significance of natural rock parent material to the spatial dispersal of these trace elements [34]. Mafic and ultramafic rocks accumulate trace metals, including $\mathrm{Cd}, \mathrm{Cr}$, and $\mathrm{Ni}$, leading to higher concentrations in soilplant systems [35]. In Pakistan, studies conducted by [36, 37] on soil and vegetable accumulation of trace metals from natural geological sources in Gilgit, northern Pakistan, and trace metals in the piedmont soils of the Peshawar Basin, Pakistan, respectively, suggested higher levels of trace elements, including $\mathrm{Cd}, \mathrm{Pb}, \mathrm{Zn}, \mathrm{Cu}, \mathrm{Cr}$ and $\mathrm{Ni}$, in agricultural soils that were primarily released from parent rocks and calcite rocks. The release of $\mathrm{Mn}$ and As mainly from natural aquifer rocks has been reported in soil and groundwater systems in different locations in Bangladesh and West Bengal, India [38, 39]. Nevertheless, although trace metals usually originate from natural sources, the type and elemental composition of parent material, the extent of the rock weathering process, the physicochemical and biological properties of soil, and the climatic environment seem to have a significant effect on the occurrence and distribution of trace elements in soil systems [40].

\subsection{Anthropogenic sources}

\subsubsection{Agricultural activities}

(a) Intensive pesticide use. The term "pesticides" includes any combination of substances intended for preventing, destroying, resisting and mitigating any pests such as weeds, nematodes, insects, mites, and rats. Consequently, it comprises insecticides, nematicides, herbicides, fungicides, molluscicides, and other materials extensively used for pest control [2]. Despite the significant influence of pesticides on worldwide agricultural production, the adverse human health effects linked with them is causing 
increasing concern [41]. However, the intensive use of insecticides has grown extensively over the past decades, and in recent decades, approximately 2.3 million tons of pesticides have been used yearly [42].

Extremely hazardous substances, such as persistent organic pollutants (POPs), organophosphates and organochlorine insecticides such as dichlorodiphenyltrichloroethane (DDT), chlordane, lindane, and chlorinated hydrocarbon endosulfan) are used in the agricultural application of different conventional pesticides reported to contain significant levels of trace elements and enter environmental matrices [43]; these pesticides are based on chemical mixtures comprising $\mathrm{Cu}, \mathrm{Ni}, \mathrm{Cr}, \mathrm{Mn}, \mathrm{Cd}, \mathrm{As}$, $\mathrm{Pb}$, and $\mathrm{Zn}[10]$. The Bordeaux mixture of copper sulfate $\left(\mathrm{CuSO}_{4}\right)$ is commonly used to control mycological attacks in several crop systems [44]. Arsenic and As-containing compounds, such as lead arsenate $\left(\mathrm{PbHAsO}_{4}\right)$ insecticides, have been intensively used in the past to control pests in different crop systems [45]. However, the intensive use of fertilizers is also common practice to reach maximum agricultural production from a unit area of land [46]. Agrochemical fertilizers usually contain significant concentrations of different trace metals and their metalloids, including $\mathrm{As}, \mathrm{Cd}, \mathrm{Cr}, \mathrm{Zn} \mathrm{Cu}, \mathrm{Mn}, \mathrm{Ni}, \mathrm{Zn}, \& \mathrm{~Pb}$ [2]. Radionuclide trace elements such as ( $\mathrm{U}, \mathrm{Ra}, \& \mathrm{Th})$ have also been introduced into agricultural soil along with fertilizers [47]. Nevertheless, some of the trace metals $(\mathrm{Cu}, \mathrm{Mn}$, $\mathrm{Mo}, \mathrm{Zn}, \mathrm{Ni}, \& \mathrm{Fe})$ at low concentrations are considered essential nutrients [48]. Agrochemical fertilizers contain significant levels of trace elements such as $\mathrm{Ni}, \mathrm{Pb}, \mathrm{Fe}, \mathrm{Co}$, $\& \mathrm{Cd}$ as impurities [2].

(b) Intensive use of fertilizers. Worldwide, the extensive use of fertilizers for agricultural purposes has increased exorbitantly in the previous six decades. In 2006, the World Resources Institute (WRI) specified that five key countries, China, the United States, India, Indonesia, and Brazil, were responsible for two-thirds of all fertilizer consumption; China ranked first with approximately 32.9\% (55925.6 thousand metric tons) consumption of total fertilizer worldwide [49]. Fertilizer usage in India has increased intensively to 133 $\mathrm{kg} / \mathrm{ha}$ in 2011 from $1 \mathrm{~kg} / \mathrm{ha}$ in 1951-1952 [49]. Among the various types of fertilizers, the application of phosphate-containing fertilizers is the most common. It is a dynamic factor in the sustained agricultural growth and high productivity of rural farming in several countries around the world [50]. 
In Asia, the typical application of phosphate-based fertilizer is approximately $34 \mathrm{~kg} / \mathrm{ha}$ [49]. However, the concentrations of pollutants in fertilizer vary significantly, especially the concentrations of trace metals. According to the literature, the application of phosphatebased fertilizer at a rate of $20 \mathrm{~kg} / \mathrm{h} /$ year in soil leads to the introduction of approximately $25 \mathrm{~g} / \mathrm{h} /$ year and $0.01 \mathrm{~g} / \mathrm{ha} /$ year of $\mathrm{Cr}$ and $\mathrm{Hg}$, respectively [49]. Phosphate-based fertilizers have been a significant source of trace metals compared with other inorganic fertilizers, as they may contain 0.1 to 170,1 to 12,7 to $38, \& 7$ to $225 \mathrm{mg} / \mathrm{kg}$ of the total $\mathrm{Cd}, \mathrm{Co}, \mathrm{Ni}, \&$ $\mathrm{Pb}$, respectively $[2,51]$. Phosphate-based fertilizers can relocate naturally available As into agricultural soil systems, which causes it to accumulate in runoff [52]. Agrarian soil in European countries can accumulate As at a rate of $7.7 \mathrm{~g} / \mathrm{ha} / \mathrm{year}$, compared with Asian countries such as China, which can accumulate As at a rate of $2.5 \mathrm{~g} / \mathrm{ha} / \mathrm{year}$ through the extensive application of phosphate-based fertilizers $[2,53,54]$. Nevertheless, phosphate fertilization may reduce metal toxicity and mobility, as well as the plants available in polluted paddy soils and other agrarian soils [55]. A field trial study was conducted in metal-contaminated soil with mining tailings in Shaoxing, China, and suggested that the addition of phosphate-based fertilizers could obviously reduce the levels of waterextractable elements such as $\mathrm{Zn}$ (11.7 to $75.3 \%), \mathrm{Pb}$ (22.0 to $81.4 \%$ ), and $\mathrm{Cd}$ (1.5 to $30.7 \%$ ) [56].

In addition to phosphate-based fertilizers, mixed fertilizers also act as significant sources of trace metal contamination in agrarian soils [57]. In China, the yearly received rates of $\mathrm{Cd}, \mathrm{Cr}, \mathrm{Pb}$, and $\mathrm{Ni}$ from phosphate-based mixed fertilizers are $0.73,28.1,6.9$, and $4.1 \mathrm{~g} / \mathrm{ha}$, respectively [53]. In China, it has been reported that approximately 1,200 tons of $\mathrm{Zn}$ and 5,000 tons of $\mathrm{Cu}$-containing fertilizers were added to agrarian lands per annum [53]. Agrarian soil contamination by trace metals through fertilizer application has been found in several countries, such as China, India, Malaysia, Bangladesh, Brazil, and certain European countries $[2,58,59]$.

Nutritionally rich wastewater provides crops with essential as well as toxic trace metals and accumulates in agrarian soil with organic matter [60]. Despite its inherent quality and shortcomings, the application of wastewater for irrigation purposes has been widely practised for many decades worldwide [61]. Primarily, in arid zones around the world, where water is a limiting factor for agrarian growth, urban wastewater is often used as a 
consistent source of irrigation for crop cultivation [62,63]. The wastewater is usually applied directly for irrigation and circumvents the essential requirements for wastewater treatment plants; the accumulation of severely toxic trace elements in agrarian soils through consistent use of wastewater has often been observed in different countries [64]. It has been estimated that approximately 20 million ha of land is irrigated with wastewater in several countries, including China, India, Bangladesh, Pakistan, Germany, and France [2, 65-67]. Depending on the primary source, the wastewater might include different trace metals, such as $\mathrm{As}, \mathrm{Zn}, \mathrm{Cd}, \mathrm{Cu}, \mathrm{Pb}, \mathrm{Cr}, \mathrm{Mn}$, or $\mathrm{Ni}$, in varying concentrations [68]. However, it has also been reported that after going through wastewater treatment plants, trace metals can persist in wastewater and can accumulate in living systems through food chains[69].

Hence, before the reuse of wastewater for agrarian purposes, significant consideration is necessary for public health as well as acceptance [70]. In an eastern suburb of Beijing, China, a study reported elevated concentrations of trace metals in wastewater-irrigated soils to be in the order of $\mathrm{Cr}(78.3)>\mathrm{Zn}(71.5)>\mathrm{Ni}(31.8)>\mathrm{Cu}(25.5)>\mathrm{Cd}(0.81) \mathrm{mg} / \mathrm{kg}$; however, in wastewater-irrigated agrarian topsoils compared with Chinese reference soils, $\mathrm{Cr}(53.8)>\mathrm{Zn}(51.9)>\mathrm{Ni}(18.7)>\mathrm{Cu}(16.0)>\mathrm{Cd}(0.36) \mathrm{mg} / \mathrm{kg}$, which are within the World Health Organization (WHO) and the national standards of China, except for Cd [2, 71]. A similar type of study was carried out in the Zhangshi wastewater irrigation area in a suburb of Shenyang City, China, in an agrarian area with about three decades of irrigation history. The elevated trace metal-containing wastewater and its measured concentrations were found to be in the order $\mathrm{Ni}(241.6)>\mathrm{Pb}(88.1)>\mathrm{Cu}(69.2) \mathrm{Cd}(2.7) \mathrm{mg} / \mathrm{kg}$; the levels were significantly elevated in wastewater-irrigated topsoil compared with those in reference soils [72].

A study conducted at the Bindal River, Dehradun, India found that wastewater irrigation caused a higher percent concentration of trace metals in agrarian soil, in the order $\mathrm{Zn}(48 \%)>$ $\mathrm{Pb}(20 \%)>\mathrm{Ni}(13 \%)=\mathrm{Cu}(13 \%)>\mathrm{Cr}(5 \%)>\mathrm{Cd}(1 \%)$, which exceeded the permissible limits defined by the WHO and by India [73]. Though the agrarian soil was irrigated with treated wastewater in Varanasi, India, the concentrations of trace metals were found in the following order: $\mathrm{Pb}(123.5)>\mathrm{Zn}(122.3) \mathrm{Cu}>(77.9)>\mathrm{Cr}(56.3)>\mathrm{Cd}$ (3.9) $\mathrm{mg} / \mathrm{kg}$; these levels exceed the limits of both the WHO and India [74]. A study conducted in Abbottabad, Pakistan, reported on the status of trace metal concentrations in municipal wastewater used 
for agrarian purposes, including $\mathrm{Cd}$ (2.8 mg/kg), $\mathrm{Cr}$ (4.2), $\mathrm{Cu}$ (28), $\mathrm{Ni}$ (7.5), $\mathrm{Zn}$ (135.6), Pb (15.6) and $\mathrm{Fe}(270) \mathrm{mg} / \mathrm{kg}$, which are below the standards defined by the USA, UK and EU [75]. However, a study conducted in Hanoi, Vietnam, in a paddy soil system found that the irrigation wastewater was contaminated with wastes from several industrial plants and reported the average concentrations of trace metals, such as $\mathrm{Cu}$ (202), $\mathrm{Zn}$ (192), $\mathrm{Pb}$ (159), and $\mathrm{Cd}(4) \mathrm{mg} / \mathrm{kg}$, which all exceeded the WHO and Vietnamese defined standards [76]. Sewage sludge or biosolids are mainly reliable organic products produced by wastewater treatment and can be constructively recycled [77].

Different waste disposal approaches, such as agricultural application, landfilling, incineration, and ocean dumping, are used based on resource accessibility [78]. Agricultural practices that use sewage sludge are widely known as an economically feasible and ecologically acceptable method of disposal [79]. Therefore, an extensive quantity of sewage sludge is directly deposited on agrarian lands in China, where approximately $10 \%$ of the total sewage sludge produced in the country is applied directly to agricultural land [80]. From an agrarian perspective, the direct use of sewage sludge is considered to be an excellent fertilization method because it can improve the physiochemical and biological properties of the soil and contains high levels of nitrogen $(\mathrm{N})$, phosphorus $(\mathrm{P})$, potassium $(\mathrm{K})$, calcium $(\mathrm{Ca})$, and other trace elements that are essential for crop growth [81, 82]. Nevertheless, elevated concentrations of trace metals such as $\mathrm{Cu}, \mathrm{Zn}, \mathrm{Cr} \mathrm{As}, \mathrm{Se}, \mathrm{Cd}, \mathrm{Mn}$, and $\mathrm{Pb}$, are often reported in sewage sludge and may cause adverse effects on humans and the environment [83,84]. Trace metal contamination in agrarian soils from the application of sewage sludge has been reported as one of the primary concerns about this method because of the long-term accumulation of trace metals in the soil-plant system [85]. Obviously, the trace metal content in sewage sludge differs by numerous factors, such as the quality of wastewater and the effectiveness and meticulousness of the treatment process [86]. Usually, the contents of trace elements in sewage sludge can vary from 0.5 to $2 \%$ on a dry basis [2]. However, the frequent application of livestock manure in agrarian soil is recognized as a vital source of trace metals in soil crop systems and causes various environmental issues and human health effects $[87,88]$. 
Livestock manure is a valuable source of organic compost that can improve paddy soil fertility as well as the organic matter content [89]. Livestock are also frequently fed with several feed additives to improve growth performance and reduce the risk of human disease $[88,90]$. However, feed additives and animal manure are significant sources of trace metals at various concentrations $[88,91]$. The continuous application of livestock manure to agrarian soil causes the accumulation of trace metals in the soil crop system and food chain, which seriously threatens the environment, the quality of plant crop production, and human health [92].

\subsubsection{Industrial activities}

Mining activities provide several socio-economic benefits but are considered some of the most hazardous activities worldwide [2,93]. Mining activities such as grinding, concentrating minerals, and tailings and mine and mill wastewater disposal are significant and confirmed sources of trace metal contamination in soil crops (Fig. 1), mainly in paddy soil-rice systems $[94,95]$. Trace metal contamination in paddy soil-rice systems through mining activities is considered a significant issue worldwide [19]. The spatial distributions of trace metal concentrations adjacent to mining sites depend on geochemical conditions, and mineralization following the release of untreated wastes into the environment may increase trace metal concentrations in agrarian soil and food crop systems [96, 97]. According to the literature, a study conducted near an abandoned copper mine in eastern China suggests that continuous mining practices may increase trace metal contamination in soils, with average metal concentrations of $\mathrm{Cu}$ (147), $\mathrm{Pb}$ (53.8), $\mathrm{Zn}$ (158), and $\mathrm{Cd}(0.32)$ $\mathrm{mg} / \mathrm{kg}[98]$.

A study conducted in paddy soils adjacent to a mining site in the Kočani field, Macedonia, was severely affected by an increased level of trace metals such as As (47.6), $\mathrm{Cd}$ (6.4), $\mathrm{Cu}(99), \mathrm{Pb}(983)$ and $\mathrm{Zn}(1,245) \mathrm{mg} / \mathrm{kg}$ because of the wide dispersal of trace metals from metal mining activities [99]. However, a similar type of study conducted in Vietnam in paddy fields adjacent to chromite mine tailings piles showed trace metal concentrations of Co $(375), \mathrm{Ni}(5,590)$, and $(5,750) \mathrm{mg} / \mathrm{kg}$ [100]. Another study was conducted in Thai Nguyen Province in northern Vietnam in paddy fields 50 metres away from a $\mathrm{Pb}$ recycling smelter and reported significantly elevated concentrations of trace 
metals, including $\mathrm{Pb}$ and $\mathrm{Cd}$, ranging from 1,100 to 7,000 and 0.5 to $1.3 \mathrm{mg} / \mathrm{kg}$, respectively [101].

In Hezhang County in China, smelting practices commonly cause $\mathrm{Cr}$ pollution ranged from 71 to $240 \mathrm{mg} / \mathrm{kg}$ in agrarian soils [102]. A study around the chromite mining site at Chikkondanahalli in the Nuggihalli schist belt, Karnataka, India, found that the status of trace metals in agrarian soil concentrations was in the order $\mathrm{Cr}(791)>\mathrm{Ni}(168.5)>\mathrm{Co}$ (21.5); these levels exceed permissible soil quality limits and suggest that the elevated levels of these elements are correlated with previous and current uncontrolled mining activities in the study area [94]. Airborne fine-grained fly ash waste, another primary source, contributes to trace metal contamination in environmental matrices [103]. The reduction in petroleum-based sources causes increasing consideration of renewable energy production, primarily through biomass, including wood, straw, and crop burning [104]. However, coal-based thermal power generation plants are still a well-known energy source in various countries, such as India, China, Pakistan, Japan, and Korea [105, 106]. Thus, the production of incinerated airborne fine-grained solid fly ash waste is considered a serious concern worldwide [107]. Substantial amounts of fly ash containing high concentrations of trace metals are produced through the incineration process [107].

Moreover, fly ash neutralizes agrarian soil acidity, improves soil structure and texture, reduces bulk density, and increases soil water and nutrient-holding capabilities, suggesting the rationality of its use in crop production [2]. Therefore, the direct use of fly ash in agricultural lands is a conventional practice that increases trace metal concentrations and bioaccumulation in crops, mainly in paddy soil-rice systems [108]. The direct disposal of hazardous waste has also been reported as a significant contributor to elevated levels of trace metals in soil-crop systems [10]. The distributions of trace metals from hazardous waste disposal sites to adjacent areas depend on various interconnected geochemical activities [109]. The distributions of trace metals to adjacent agricultural soils are usually influenced by soil $\mathrm{pH}$, oxidation-reduction potential (ORP), and the availability of involved agents such as carbonates, sulfates, chlorides, microbial activities, organic, and hazardous waste properties $[110,111]$.

A study was conducted in Dholpur district, Rajasthan, India, and reported trace metals, including $\mathrm{Cr}, \mathrm{Cu}, \mathrm{Fe}, \mathrm{Ni}, \mathrm{Pb}$, and $\mathrm{Zn}$, with elevated concentrations at dumpsites 
(34.56 \pm 1.05 to $110.75 \pm 2.59 \mathrm{mg} / \mathrm{kg}$ ) [112]. A similar study was conducted adjacent to dumping sites in Allahabad, Uttar Pradesh, India, and proposed that the soil $\mathrm{pH}$ was negatively correlated with $\mathrm{Ni}$ and $\mathrm{Fe}$, though the contents of $\mathrm{Zn}$ were significantly positively correlated with $\mathrm{Pb}$ and $\mathrm{Cu}$ [113]. However, in the northwest region of Hyderabad, India, several hazardous waste dumping sites exist where approximately 50,000 tons of hazardous/industrial waste is abandoned yearly in landfills, which causes elevated trace metal contamination in adjacent soil, including $\mathrm{Cr}$ (127.9), As (51.7) and $\mathrm{Pb}$ (206.4) mg/kg [110].

The increase in the global population has increased the use of electronic appliances, which cause 20 to 50 million tons of annual production of e-waste worldwide, which is a serious concern $[114,115]$. E-waste can also cause pollution from numerous trace metals. [116]. The reviewed status of trace metal contamination in soil systems due to e-waste in China comprises several study results suggesting $\mathrm{Cu}$ and $\mathrm{Cd}$ concentrations of thousands of $\mathrm{mg} / \mathrm{kg}$ beyond the permissible limits of 50 and $0.3 \mathrm{mg} / \mathrm{kg}$ for agrarian soils [115].

However, in a study conducted in Taizhou, China, paddy fields adjacent to an e-waste recycling zone contained trace metal concentrations of $61.21,98.81,1.19$, and $55.81 \mathrm{mg} / \mathrm{kg}$ for $\mathrm{Cr}, \mathrm{Cu}, \mathrm{Cd}$, and $\mathrm{Pb}$, respectively, which were beyond the background values [117]. Another similar study conducted in southeastern Zhejiang Province in China investigated paddy fields near an e-waste recycling areas and found trace metal concentrations of 20.95, 97.90, 298.31, 0.62, and $44.29 \mathrm{mg} / \mathrm{kg}$ for $\mathrm{Cr}, \mathrm{Cu}, \mathrm{Zn}, \mathrm{Cd}$, and $\mathrm{Pb}$, respectively, which were far beyond the background values [31].

Fig. 1.

\section{Trace element basic chemistry, behaviour in the soil system, and associated risks}

Although trace metals play a significant role in crop production, they may reduce crop production because of the risk of bioaccumulation and biomagnification in the food chain [118]. A basic knowledge of trace metal chemistry, transport, environmental fate, and related human health effects is required to understand their speciation and bioavailability as well as the remediation options [10].

The transport and fate of trace metals in soil crop systems mainly depend on the bioavailability, chemical form, and speciation of trace metals [119]. Once in the soil system, trace metals are absorbed through initial reactions that occur in minutes to hours, followed 
by slow adsorption reactions that occur in days to years; thus, their conversion and redistribution into numerous chemical forms with varying mobility, toxicity, and bioavailability take place [120]. The dispersal and reactions of trace metals in the soil system are likely controlled by several factors, such as mineral dissolution and precipitation, metal ion exchange capacity, adsorption or desorption, biological mobilization or immobilization, soil-plant availability and uptake size and aqueous complexation (Table 1) [10].

\subsection{Arsenic}

Arsenic mainly occurs in different compounds such as $\mathrm{As}_{2} \mathrm{O}_{3}$, and can be recovered by the processing of ores usually containing $\mathrm{Pb}, \mathrm{Zn}, \mathrm{Ag}, \mathrm{Cu}$ and $\mathrm{Au}$ [121]. There are four natural processes, i.e., reductive dissolution, sulfide oxidation, alkali desorption, and geothermal activities, involved in the release of As to the environment [122]. Two main species of As exist in the terrestrial environment: inorganic pentavalent arsenic, arsenate As(V) under oxidizing (aerobic) conditions, and trivalent arsenite As(III) under reducing (anaerobic) conditions $[22,123]$. As $(\mathrm{V})$ is dominant, primarily in the form of arsenate ions $\left(\mathrm{AsO}_{4}{ }^{3-}\right)$ in different states, such as arsenic acid $\left(\mathrm{H}_{3} \mathrm{AsO}_{4}\right)$, dihydrogen arsenate $\left(\mathrm{H}_{2} \mathrm{AsO}_{4}{ }^{-}\right)$, hydrogen arsenate $\left(\mathrm{HAsO}_{4}{ }^{-}\right)$and arsenate ions $\left(\mathrm{AsO}_{4}{ }^{3-}\right)[10,124]$. Thus, As and $\mathrm{As}(\mathrm{V})$ act as chelates and can easily precipitate once cations are present [125]. The As(V) complexes are stable under specific conditions and coprecipitate and absorb Fe-oxyhydroxide under reducing and/or partially reducing conditions. The coprecipitates are immobile under these particular environmental conditions; nevertheless, the mobility of As increases with an increase in $\mathrm{pH}[126,127]$. However, under anaerobic conditions, As(III) is the dominant species of As, existing as an arsenite ion $\left(\mathrm{AsO}_{3}{ }^{3^{-}}\right)$and its protonated forms, such as arsenious acid $\left(\mathrm{H}_{3} \mathrm{AsO}_{3}\right)$, dihydrogen arsenite $\left(\mathrm{H}_{2} \mathrm{AsO}^{3-}\right)$ and hydrogen arsenite $\left(\mathrm{HAsO}_{3}{ }^{2-}\right)$ (Table S2) [10]. As(III) can coprecipitate or can adsorb with sulfides $\left(\mathrm{S}^{2-}\right)$ and has an affinity to bind with other sulfur compounds [128]. As(III) and arsine $\left(\mathrm{AsH}_{3}\right)$ usually exist under highly anaerobic conditions [129]. The main routes of human As exposure include drinking water and food [130]. The bioaccumulation of As in living systems (plants \& humans) takes place through methylation, which generates highly volatile methylated derivates of $\mathrm{AsH}_{3}$ compounds such as dimethyl arsine $\left(\mathrm{HAs}\left(\mathrm{CH}_{3}\right)_{2}\right)$ and trimethyl arsine 
$\left(\mathrm{HAs}\left(\mathrm{CH}_{3}\right)_{3}\right)$ [131]. Arsenic usually exists in anionic forms that do not exhibit an affinity to bind with anions, including chloride $\left(\mathrm{Cl}^{-}\right)$and sulfates $\left(\mathrm{SO}_{4}{ }^{2-}\right)$, to form complexes [132].

Arsenic can also exist in organometallic forms, which include methyl arsenic acid $\left(\left(\mathrm{CH}_{3}\right)\right.$ $\left.\mathrm{AsO}_{2} \mathrm{H}_{2}\right)$ and dimethyl arsenic acid $\left(\left(\mathrm{CH}_{3}\right)_{2} \mathrm{AsO}_{2} \mathrm{H}\right)$ [10]. The modes of toxicity for As(III) and $\mathrm{As}(\mathrm{V})$ are different [133]. As(III) is sixty times more toxic and carcinogenic to humans than $\mathrm{As}(\mathrm{V})$ [134]. As(III) can bind with tissues for a longer period than $\mathrm{As}(\mathrm{V})$, which binds with specific groups of proteins that cause $\mathrm{As}(\mathrm{V})$ to act biologically against phosphate, distressing the production of ATP synthesis $[135,136]$. Long-term exposure to As damages the human cardiovascular, dermal, neurological, hepatic, respiratory, and reproductive systems (Fig. 1) [137].

\subsection{Selenium}

Selenium exists in different oxidation states that permit the production of organoselenium and selenoamino acid complexes [138]. In the soil system, selenate $\left(\mathrm{SeO}_{4}{ }^{2-}\right)$ and selenite $\left(\mathrm{SeO}_{3}{ }^{2-}\right)$ are stable for extended periods [139]. Several $\mathrm{Se}(\mathrm{VI})$ compounds exist in soil, but only $\mathrm{SeO}_{4}{ }^{2-}$ usually occurs in normal $\mathrm{pH}$ ranges, and the most dominant form of $\mathrm{Se}(\mathrm{IV})$ below soil $\mathrm{pH} 8.5$ is hydrogen selenite $\left(\mathrm{HSeO}_{3}{ }^{-}\right)$[139]. Selenium is an essential trace element for animals and humans at a certain level; for adults, the recommended dietary allowance (RDA) of $\mathrm{Se}$ is $55 \mu \mathrm{g} /$ day $[123,140,141]$, and an excessive amount of Se can cause severe toxicity. Se(IV) is commonly used as a feed additive in different commercial animal diets with a recognized Se dose of $0.5 \mathrm{mg} / \mathrm{kg}$ in the whole feed [142]. In humans, Se intake varies across various countries [143].

Overall, Se consumption for adults ranges from 93 to $134 \mu \mathrm{g} /$ day in North American regions, the optimal Se consumption ranges from 52 to $64 \mu \mathrm{g} /$ day in Western Europe/France, and low levels of Se consumption range from 30 to $40 \mu \mathrm{g} / \mathrm{day}$ in Eastern European countries/Poland [142]. This metalloid is also known as a cancer chemopreventive compound and is indispensable for proper cell function [141]. Numerous mechanisms have been reported regarding the chemoprotective effects of Se, such as antioxidant protection, reduction in carcinogen metabolism effects, enhancement of the immune surveillance system, and inhibition of the angiogenesis process and cell cycle [144, 145]. Approximately 0.5 to 1 billion people worldwide suffer from Se deficiency [146], which makes them prone to several diseases, such as white muscle and Keshan disease 
[147]. Selenium deficiency occurs in humans when Se intake is $<40 \mu \mathrm{g} / \mathrm{d}[148,149]$ and may cause reduced bone metabolism, growth obstruction, irregularities in thyroid function, reduced fertility, immune system complications and even cancer [148, 150, 151]. Inorganic Se is 40 times more toxic than organic Se [152]. However, higher intake levels of Se $>400$ $\mu \mathrm{g} / \mathrm{d}$ [149] can lead to severe toxic effects in humans, such as skin lesions, nail and hair loss, nervous disorders, amyotrophic lateral sclerosis, diabetes, and paralytic symptoms leading to death $[153,154]$.

\subsection{Cadmium}

Cadmium $(\mathrm{Cd})$ is toxic. This nonessential transition element occurs directly below $\mathrm{Zn}$ in the periodic table due its chemical similarity with $\mathrm{Zn}$; in compounds, $\mathrm{Cd}(\mathrm{II})$ exists as a divalent ion $[10,155]$. This may be part of the reason for Cd toxicity; since $\mathrm{Zn}$ is a wellknown essential element, the substitution of $\mathrm{Cd}$ for $\mathrm{Zn}$ can damage several functions of the metabolic process [156]. Cadmium is present as an impurity in different products, such as detergents, phosphate-based fertilizers, and different petroleum-based products, and is also a component of acid rain, which increases soil acidification and thereby increases $\mathrm{Cd}$ mobility [157].

Rice is a significant source of human Cd risk, and the basic chemistry of Cd in reducing soils is important [158]. Both $\mathrm{Cd}$ and $\mathrm{Zn}$ primarily co-occur in sphalerite in robust solutions as $\mathrm{CdS}$ and $\mathrm{ZnS}$ [159]. As soon as sphalerite is mixed in aerobic soils and sulfur oxidation by microorganisms occurs, soluble $\mathrm{Cd}$ and $\mathrm{Zn}$ are released into the ground and react with soils [139]. In flooded paddy soils, numerous chemical changes occur that may affect the phytoavailability of $\mathrm{Cd}$ and $\mathrm{Zn}[160]$. The reduction of the physicochemical contents of soil increases the concentration of the CdS complex. When flooded soils drain, a decrease in soil physicochemical contents and CdS complex concentrations occurs due to rapid oxidation and increased soil Cd phytoavailability; $\mathrm{Zn}$ has little effect on the yield of rice grains that contain a high level of $\mathrm{Cd}$ at harvest [139]. Rainfall during the rice grain filling period can slow paddy soil oxidation and reduce $\mathrm{Cd}$ accumulation in rice grains, causing variation in the $\mathrm{Cd}$ level in rice grains from year to year [161].

Excessive Cd intake may cause several human health effects, such as renal damage caused by proteinuria due to $\mathrm{Cd}$ severely affecting the enzymes that reabsorb proteins in kidney tubules [162]. The most remarkable occurrence of Cd toxicity due to excessive 
dietary Cd intake happened in the Jinsu River Valley, Fuchu, Japan, where people were afflicted by itai-itai disease [162]. Other health symptoms of $\mathrm{Cd}$ exposure include painful osteomalacia and kidney failure [10].

\subsection{Lead}

Lead $(\mathrm{Pb})$ is a bluish-gray metal that naturally occurs in soil and rocks; it belongs to the IV group in the periodic table with atomic number 82 [163]. Lead is usually found in metal form at concentrations ranging from 10 to $30 \mathrm{mg} / \mathrm{kg}$ in the Earth's crust. $\mathrm{Pb}$ is considered a chalcophile metal with a strong affinity for $\mathrm{S}$ as well as other elements, and is found in forms such as $\mathrm{PbS}, \mathrm{PbSO}_{4}, \mathrm{PbCO}_{3}$, i.e., galena, lead sulfate, and lead carbonate, respectively [10].

While only an insignificant amount of the total $\mathrm{Pb}$ existing in soil is bioavailable, the key pools of $\mathrm{Pb}$ in soils are in soil solution [164]. Lead adsorption on the surface of clayhumus particles can be found in compounds, precipitated forms, secondary iron (Fe) and manganese (Mn) oxides, basic earth carbonates, soil humus and silicate matrices [139]. $\mathrm{Pb}$ (II) complexes are mainly ionic, including $\mathrm{Pb}^{2+} \mathrm{SO}_{4}{ }^{2-}$, and $\mathrm{Pb}$ (IV) complexes have a tendency to be covalent, such as tetra lead $\mathrm{Pb}\left(\mathrm{C}_{2} \mathrm{H}_{5}\right)_{4}$; a few $\mathrm{Pb}(\mathrm{IV})$ compounds such as $\mathrm{PbO}_{2}$ are considered active oxidants [10].

Previous studies have confirmed that soil solution $\mathrm{Pb}$ is the primary source for plant uptake, with a balance occurring among the soil solution and the more 'exchangeable' or 'labile' pools of $\mathrm{Pb}$ in the soil medium [139]. In some soil solutions, $\mathrm{Pb}$ might be concentrated with calcium carbonate $\left(\mathrm{CaCO}_{3}\right)$ or phosphate [165]. Elevated concentrations of $\mathrm{Pb}$ in the soil lead to the formation of pyromorphite $\left(\mathrm{Pb}_{5} \mathrm{Cl}\left(\mathrm{PO}_{4}\right)_{3}\right)$, which mainly occurs near the plant root system, and the solubility of $\mathrm{Pb}$ in soils primarily depends on $\mathrm{pH}$ [166]. The increased $\mathrm{pH}$ in soil can precipitate $\mathrm{Pb}$ in forms such as carbonate, phosphate or hydroxide, and can also lead to the formation of moderately Pb-organic mixtures [166]. Increasing soil acidity leads to increased solubility and mobilization of $\mathrm{Pb}$, usually at a slower rate than the rate of $\mathrm{Pb}$ accumulation in the soil organic layer [167].

Several studies have reported that $\mathrm{Pb}$ adsorption significantly depends on the types of ligands involved in the formation of hydroxyl compounds of $\mathrm{Pb}$, such as $\left(\mathrm{PbOH}^{+}\right) \&$ $\mathrm{Pb}_{4}\left(\mathrm{OH}_{4}\right)^{4+}[166,168]$. However, it has been further suggested that the adsorption of these complexes on montmorillonite might be an interrupted cation exchange process, unlike that 
on kaolinite and illite [166]. In soil solution, the higher sorption of $\mathrm{Pb}$ via manganese oxide, iron oxide, halloysite, and imogolite by kaolinite, montmorillonite, and humus was observed [166, 169]. High Pb intake can cause serious health effects, especially in children who are more vulnerable to $\mathrm{Pb}$ toxicity, leading to lower IQ, mental deterioration, impaired development, reduced attention span, and hyperactivity [170]. In adults, $\mathrm{Pb}$ exposure can cause memory loss, joint weakness, damage to the cardiovascular system, and other negative effects [171].

\subsection{Zinc}

In soil systems, the mobility of Zn depends on the solubility of its speciated form and on the soil properties, including $\mathrm{pH}$, cation exchange capacity, redox potential and the availability of metal species in the soil; under oxidizing conditions, zinc sulfide $(\mathrm{ZnS})$ is the dominant species in soil [172]. However, $\mathrm{ZnS}$ is insoluble, and the mobility of $\mathrm{Zn}$ is low in oxidizing soils since, at higher soil $\mathrm{pH}$ levels, $\mathrm{Zn}$ adsorption is reduced, resulting in the release of organic $\mathrm{Zn}$ complexes and increased concentrations of chelating agents in the soil system [173].

At high $\mathrm{pH}$ levels, the $\mathrm{Zn}$ in the soil solution is primarily precipitated as zinc hydroxide $\mathrm{Zn}(\mathrm{OH})_{2}$ and/or zinc carbonate $\left(\mathrm{ZnCO}_{3}\right)$ [174]. In soil solution, clay and metal oxides have the capacity to sorb $\mathrm{Zn}$ and tend to retard its mobility [175]; at $\mathrm{pH} \mathrm{4,} \mathrm{Zn}$ is more mobile than that at $\mathrm{pH} 6.5$ due to sorption [173]. Goethite, iron hydroxide $\mathrm{Fe}(\mathrm{OH})_{3}$, may also reduce $\mathrm{Zn}$ mobility in soil and increase retardation; this effect has also been reported with humic acid [176]. Zinc can disturb the activity of soil organisms, including decreasing microbe and earthworm activity, which delays the breakdown of organic matter [177]. Excessive $\mathrm{Zn}$ intake can cause acute and chronic toxic effects on human health, such as nausea, loss of appetite, vomiting, abdominal cramps, headaches, and diarrhoea [178].

\subsection{Manganese}

The most significant, dominant, and stable forms of Mn primarily persist in rockforming minerals [179]. The $\mathrm{Mn}^{2+}$ cation is considered a substitute for $\mathrm{Fe}^{2+}$ and $\mathrm{Mg}^{2+}$ in silicates and oxides [179]. In the soil development process, Mn primarily accumulates as oxides and hydroxides; consequently, the total Mn concentration in agricultural soil is substantially higher than that of other elements [180]. Mn-containing vital minerals are mostly ferromagnesian silicate minerals such as chlorite, biotite, and hornblende [181]. 
During the mineral weathering process, Mn complexes oxidize under atmospheric environments, leading to the rapid release and transformation of $\mathrm{Mn}$ into the oxides or hydroxides of secondary minerals that accumulate in the soil system [179]. Manganese oxides have an affinity to coprecipitate with $\mathrm{Fe}$ oxides [182]; therefore, Mn oxides accumulate in soil horizons with Fe oxides and hydroxides [183]. Low concentrations of total $\mathrm{Mn}$ in soils persist in dissolved forms, primarily adsorbed on mineral surfaces or chelated with organic matter, and these forms contribute to the Mn pool that is available to plants [179]. $\mathrm{Mn}(\mathrm{II})$ is the most dominant species of $\mathrm{Mn}$ in equilibrated soil solutions on exchange sites on soil surfaces [40]. Mn(III) and Mn(IV) are mainly associated with solid soil phases and exist as oxides such as carbonates and phosphates [179]. $\mathrm{Mn}^{2+}$, the primary plant-available form of $\mathrm{Mn}$, is complexed with organic or inorganic ligands, and its concentrations in the soil system decrease with increasing $\mathrm{pH}$ [184]. Under anaerobic conditions, the $\mathrm{Mn}^{2+}$ concentration in soil solutions of extremely weathered soils, including oxisols and ultisols, might be a significant cause of agricultural crop toxicity, such as that in rice plant systems $[179,185]$. The main inorganic complexes and pairs of ions, such as $\mathrm{MnCO}_{3}, \mathrm{MnHPO}_{4}, \mathrm{MnSO}_{4}, \mathrm{Mn}(\mathrm{OH})^{+}$, and $\mathrm{MnMnCl}_{2}$, in Mn-rich soil solution are readily soluble in the water system and are the most bioavailable [139]. In soil solution, Mn(II) forms complexes with organic materials, including humic acid, organic acid, and amino acid [186].

However, the $\mathrm{Mn}^{2+}$ that is firmly bound to fulvic acid remains thoroughly hydrated, and the complex formed between $\mathrm{Mn}^{2+}$ and humic substances might be described as an outersphere complex where ligands do not directly bond with Mn electrons [179]. Mn-organic ligand complexes can be quite labile and exist in crop plants and microbes [187]. Although Mn plays a vital role in several physiological and biochemical processes in plants and humans, Mn deficiency can severely inhibit plant crop growth and human health [188]. Excessive Mn concentrations are toxic to plants and humans [189]. In humans, Mn toxic effects usually occur in the brain and respiratory tract, and significant symptoms of $\mathrm{Mn}$ toxicity include Parkinson's disease, hallucinations, forgetfulness, nerve damage, lung embolisms, and bronchitis [190, 191]. 


\subsection{Nickel}

In soil solution, nickel (Ni) occurs as the aqueous nickelous ion $\mathrm{Ni}^{2+}$, which can form complexes with organic/inorganic ligands or with suspended mineral colloids [192]. Organic complexes, rather than different inorganic species such as $\mathrm{Ni}^{2+}, \mathrm{NiCO}_{3}, \mathrm{HiCO}_{3}{ }^{+}$, and $\mathrm{NiOH}^{+}$, are typically the most dominant $\mathrm{Ni}$ species in soil solution [192].

The behaviour of $\mathrm{Ni}$ is also $\mathrm{pH}-$ dependent; at low $\mathrm{pH}, \mathrm{Ni}$ occurs in the form of $\mathrm{Ni}^{2+}$, whereas in neutral to high-pH soil solutions Ni precipitates as stable nickelous hydroxide $\mathrm{Ni}(\mathrm{OH})_{2}$ compounds $[10,193]$. Nickel is radially dissolved in acidic soil solutions to form $\mathrm{Ni}^{3+}$, and very in basic soil solutions it forms nickelate compounds $\left(\mathrm{HNiO}_{2}\right)$ which are soluble in water [10]. Notably, the total $\mathrm{Ni}$ content in soils, the significant sources of $\mathrm{Ni}$ in soils, including geogenic and anthropogenic sources, and the physicochemical characteristics of soils influence the partitioning of $\mathrm{Ni}$ between solution and its solid phase in soil; these factors control Ni mobility and bioavailability $[192,194]$. Nickle occurs in crucial minerals, mainly allied with oxides of $\mathrm{Mn}$ and Fe and layered silicates, such as chlorite, garnierite and vermiculite [195]. In serpentine soils with a high concentration of $\mathrm{Ni}$ and basic $\mathrm{pH}$, Ni can partially bind with carbonates [196]. In solution, Ni has an affinity to rapidly adsorb on the surfaces offered by the soil solid phase such as layered silicates, $\mathrm{Fe}(\mathrm{Al}), \mathrm{Mn}$-oxides, and organic matter [197], and can form inner or outer-sphere surface complexes [192, 198].

Nickle adsorption by the formation of outer-sphere surface complexes is radially exchangeable because $\mathrm{Ni}$ species occur as hydrates and loosely attach to outer-sphere surfaces of the solid soil phase through electrostatic force and by $\mathrm{H}$-bonding between hydration shells and surface oxygen [199]. In contrast, Ni species adsorbed on the innersphere surface complexes are partly dehydrated or dehydrated species [192].

Compared with other trace elements, the adsorption affinity of $\mathrm{Ni}^{2+}$ ions for soil mineral materials is usually lower than that of $\mathrm{Zn}^{2+}, \mathrm{Pb}^{2+}$, and $\mathrm{Cu}^{2+}$ [200]. The stoichiometric precipitates, i.e., nickel phosphate $\mathrm{Ni}_{3}\left(\mathrm{PO}_{4}\right)_{2}$ and nickel ferrite $\left(\mathrm{NiFe}_{2} \mathrm{O}_{4}\right)$, are seldom responsible for controlling the $\mathrm{Ni}$ concentration in soil solution, even in severely fertilized and contaminated soils [192]. However, Ni precipitates are mostly detectable on clay mineral surfaces and $\mathrm{Al}$ oxides at sorption densities lower than the theoretical monolayer 
of Ni sorption [201]. Moreover, these precipitates can form at circumneutral $\mathrm{pH}$ with saturated concentrations of $\mathrm{Ni}$ in solution via the solid phases of $\mathrm{Ni}$ [202].

The most important factor affecting the behaviour of $\mathrm{Ni}$ in soils appears to be $\mathrm{pH}$, though several characteristics, including the clay content and $\mathrm{Fe}$ and $\mathrm{Mn}$ oxides in soils, are considered of secondary importance [203]. The mobility of Ni in the soil system increases as the $\mathrm{pH}$ and cation exchange capacity decrease [204]. Several other factors, including waterlogging (redox), organic composts, and sewage sludge in the soil, also affect the fate and transport behaviour of $\mathrm{Ni}$ in soils [205]. At low levels, $\mathrm{Ni}$ is considered an essential element for plants, humans, and animals, but a high intake of Ni leads to serious human and animal health effects and is toxic to plants [206]. The most significant human health problems caused by $\mathrm{Ni}$ exposure include chronic bronchitis, lung cancer, nasal sinus damage, and reduced lung function [207].

\subsection{Chromium}

Chromium (Cr), a transition metal, does not exist naturally in elemental form, only in compounds [163]. The significant natural source of $\mathrm{Cr}$ in soil is primarily ore products such as mineral chromite, while anthropogenic sources of $\mathrm{Cr}$ include electroplating and $\mathrm{Cr}$ containing industrial waste [208]. $\mathrm{Cr}(\mathrm{VI})$ is the main form of $\mathrm{Cr}$ found at contaminated sites. Its presence depends on the $\mathrm{pH}$ and redox conditions. $\mathrm{Cr}$ also occurs in the $(+\mathrm{III})$ oxidation state since $\mathrm{Cr}(\mathrm{IV})$ is significantly dominant in shallow aquifers where oxidizing conditions exist [209]. The main $\mathrm{Cr}$ species, such as chromate $\left(\mathrm{CrO}_{4}{ }^{2-}\right)$ and dichromate $\left(\mathrm{Cr}_{2} \mathrm{O}_{7}^{2-}\right)$, can be precipitated in the presence of metal cations, including silver, barium, and lead ions $\left(\mathrm{Ag}^{+}, \mathrm{Ba}^{2+} \& \mathrm{~Pb}^{2+}\right.$ respectively) [10].

$\mathrm{CrO}_{4}{ }^{2-}$ and $\mathrm{Cr}_{2} \mathrm{O}_{7}{ }^{2-}$ adsorb on soil surfaces, particularly on aluminium and iron oxides [210]. At low $\mathrm{pH}<4, \mathrm{Cr}$ (III) is the more dominant form of $\mathrm{Cr}$, and $\mathrm{Cr}$ (+III) may form complexes with ammonia, hydroxide, chloride, fluoride, cyanide, or sulfate $\left(\mathrm{NH}_{3}, \mathrm{OH}^{-}\right.$, $\mathrm{Cl}^{-}, \mathrm{CN}^{-}$or $\mathrm{SO}_{4}{ }^{2-}$, respectively) and with soluble organic ligands [10]. $\mathrm{Cr}(\mathrm{VI})$ is considered a more toxic and more mobile form of $\mathrm{Cr}$. The mobility of $\mathrm{Cr}(\mathrm{III})$ is also decreased through adsorption on clay and oxide minerals at low $\mathrm{pH}<5$, and it is less soluble at $\mathrm{pH}>5$ due to the formation of the chromium hydroxide $\left(\mathrm{Cr}(\mathrm{OH})_{3}\right)_{(\mathrm{s})}$ complex $[10,211]$.

The mobility of $\mathrm{Cr}$ depends on the sorption features of the soil, the clay content in soil, the iron oxide content, and the availability of organic matter [210]. The soluble and 
precipitated forms of $\mathrm{Cr}$ are transported by surface runoff to surface water bodies [212], while soluble and unadsorbed $\mathrm{Cr}$ complexes can leach from the soil to aquifers; the leaching ability of $\mathrm{Cr}(\mathrm{VI})$ increases as the soil $\mathrm{pH}$ increases [10]. Human health risks associated with elevated $\mathrm{Cr}$ intake include respiratory distress, irritation, loss of body weight, and allergic dermatitis [213].

\section{Mechanisms of trace element uptake, translocation, and accumulation in paddy soil-rice systems}

A range of different trace elements generally exists in soil systems. Paddy plants can acquire the required trace elements from the soil as micronutrients [1]. The uptake, translocation, and accumulation of different trace metals in different paddy plant parts followed the order root $>$ shoot $>$ leaf $>$ husk $>$ grain, and the concentrations of these trace metals in plant parts depend on the exposure level [214]. Trace metals such as $\mathrm{Zn}$ and $\mathrm{Cu}$ are essential for paddy plant growth and sustenance; however, higher uptake, translocation, and accumulation of essential or nonessential trace metals can lead to toxicity and inhibit the growth and production of paddy rice [215]. The root zone (rhizosphere) of paddy plants and soil microbes play a significant role in trace metal availability as well as uptake and translocation to paddy plant systems [216]. Trace metals can be bound to soil particles or precipitated, which might make a crucial portion of trace metals insoluble or unavailable to paddy plants [216]. Several microbial communities in the rhizosphere of paddy plants can catalyse redox reactions in the soil system that can change the mobility of trace metals and the tendency of paddy plants to take up metals [217]. In metal-rich soils, after the biodegradation or biotransformation of trace metals, plants can accumulate specific trace metals in their tissues (accumulators) or, in the same way, restrict metal uptake into their biomass (excluders) $[49,218]$. However, paddy plants are considered strong trace metal accumulators [219].

In paddy plants, the uptake, translocation, and accumulation of essential, toxic and potentially toxic trace elements in their biomass depends on environmental and biogeochemical factors such as the availability of soil microbes; the availability of trace elements, exudates, and chelating agents produced by plants; the $\mathrm{pH}$ changes induced by oxidation-reduction reactions; and the availability of transporters and cotransporters embedded in the plant cell plasma membrane [49, 220]. Specific transporter proteins 
generally involved in trace metal uptake and translocation, such as adenosine triphosphate proteins (ATPases), produce electrochemical gradients and consume energy [49, 221].

The co- and anti-transporter proteins generally use the electrochemical gradients generated by ATPases, and different ion channel proteins facilitate the normal transport of ions in plant cell systems $[49,222]$. Nevertheless, several studies have reported that the cotransportation of cations is a common phenomenon, and potentially toxic trace metals that do not have any known biological or beneficial function, such as $\mathrm{As}, \mathrm{Cd}$, and $\mathrm{Pb}$, are mostly transported throughout paddy systems via transportation systems [49]. In the root zone of paddy plants, the immobilization of and controlled access to trace metals might be achieved through root exudates [223] that chelate trace metals to prevent their uptake into root cells, such as Ni chelation; exudates can also bind $\mathrm{Cu}$ or $\mathrm{Zn}$ in the apoplast [49]. Therefore, the chemical properties of the rhizosphere and the cell walls in the roots may control trace metal uptake, translocation, and accumulation in paddy plants [224]. Transporter proteins in the plasma membrane of plant root cells and the tonoplast of the cytoplasm [225] can maintain the physicochemical concentrations of and stress responses to trace metals, contributing significantly to trace metal homeostasis in the plant [49]. In paddy plant systems, approximately 13 putative ZIPs are a significant group of trace metal transporters that are primarily involved in the translocation of divalent cations across plant cell membranes [226]. ZIPs also exist in other plant species as well as in microbes, fungi, and animals [227].

These specific proteins are topologically analogous to the eight transmembrane protein (TP) domains, with the $\mathrm{N}$ - and $\mathrm{C}$-termini uncovered to the apoplast, and a histidine-rich cytoplasmic circle skirted via transmembrane domains (III) and (IV) is commonly involved with the binding of trace metals $[49,228]$. In paddy plant systems, As uptake depends on the As concentration gradient between the source and sink [229]. The As uptake in the plant cell (Fig. 2a) mainly depends on As species such as arsenate (As(V)) and uses different phosphate transporters $(\mathrm{Pi})$ that belong to the PHT1 family because $\mathrm{P}$ is chemically similar to As(V) (Table S2) [218].

Arsenite (As(III)) uses silicon (Si) transporters such as Lsi1 (aquaporin NIP2;1) and Lsi2 (an efflux carrier) due to the resemblance between As(III) and Si [230]. As(III) is absorbed by the aquaglycoprotein nodulin-like natural proteins (NIPs) [230]. Under Si deficiency, 
the expression of Si influx transporters (Lsi1\& Lsi2) increases [231]. The accumulation of $\mathrm{Si}$ in plant cells is mostly controlled by the Lsi1 and Lsi2 transporters, which are mostly located at the proximal or distal flanks of epidermal and endodermal cells; these cells help in the transportation of As across the plant's cells and tissues [229]. Several studies have suggested that the reduction of As occurs mainly in root cells before its transport to xylem and the rest of the plant [232]. The main As species, As(III) and As(V), are primarily found in the xylem sap of plants [233]. Of the low concentration of total As absorbed through plant roots, only a very small amount is sequestered in leaf, shoot, and grain vacuoles due to As reduction, and the sequestration mechanisms are similar to those of the roots [230]. Hence, the presence of $\mathrm{As}(\mathrm{III})$ and $\mathrm{As}(\mathrm{V})$ in phloem is a requirement for its distribution to other parts of the plant [234], while Se translocation in plant shoots, leaves, and grains depends on the rate of transpiration and the rate of xylem loading [150, 235].

Selenium uptake in the plant system is facilitated by transporters (Fig. 2b). Selenite (Se(IV)) and selenate (Se(VI)) are transported through phosphate and sulfate channels [147]. Se(VI) enters the plasma membrane of plant root cells using sulfate transporters [236], and Se(IV) and $\mathrm{P}$ compete to cross the plasma membrane of paddy plant root cells using $\mathrm{P}$ transporters [237]. $\mathrm{Se}^{\mathrm{IV}}$ and $\mathrm{P}$ compete and enter the plasma membrane of plant root cells by $\mathrm{P}$ transporters [237]. The P-induced increase in Se bioavailability most likely occurs through the exchange of Se at sorption sites, therefore increasing Se mobility and uptake in the plant [147]. In plant cells, Se typically accumulates in vacuoles and effluxes with $\mathrm{S}$ transporters present in the tonoplast $[238,239]$. Selenium, after entering plant cells with the help of the sulfate transporter, is translocated to other parts of the plant, i.e., the shoots, leaves, and grain [240], and is metabolized in plastids through the S integration pathway into selenomethionine (SeMet) or selenocysteine (SeCys); the S chemical analogue with Se can become more methylated and evaporate in a nontoxic form [241].

In paddy plants, the uptake, translocation, and accumulation of potentially toxic trace metals such as $\mathrm{Cd}$ from the paddy soil-rice (root cells to shoots) system are generally facilitated by ZIP (OsIRT1) transporters [242]. These ZIP transporters are essential for paddy plants, and the plant capacity for critical trace metal accumulation is associated with the level of ZIP expression [243]. In the Cd uptake, translocation, and accumulation mechanism in the paddy soil-rice system, $\mathrm{Cd}$ travels from the soil to the above-ground parts 
of the rice plants. Cadmium is mainly absorbed through rice root cells from the paddy soil and is translocated to other rice parts (shoots and leaves), finally accumulating in the rice grains (Fig. 2c). In the $\mathrm{Cd}$ absorption process, xylem plays a significant role in the transportation of $\mathrm{Cd}$ from root cells to shoot cells, and the phloem pathway is used in the translocation of Cd to the rice grains [214]. ZIP transporter-like OsIRT1 and OsIRT2 might show influx activity for $\mathrm{Cd}^{2+}$ ions. Therefore, it has been reported that OsIRT transporters play a significant role in $\mathrm{Cd}$ uptake through roots in paddy fields [214]. However, NRAMP3 and NRAMP4 transporters and their cotransporters also play a crucial role in Cd transport and homeostasis as well as in the resistance to the toxic effects of $\mathrm{Cd}$ in paddy plants [244]. Furthermore, the high concentrations of $\mathrm{Cd}$ and $\mathrm{Mn}$ in paddy plants are primarily facilitated by NRAMP5 transporters [245].

Additionally, the Fe transporter-like OsNramp1 also functions as Cd influx transporters in the plant plasma membrane. It has been reported that $\mathrm{Cd}$ is readily transported in paddy plants from root cells to shoot cells through culms and slants and accumulates in nodes [246]. The ABC transporter family is involved in $\mathrm{Pb}$ and $\mathrm{Cd}$ transportation from outside the plasma membrane to inside the plasma membrane $[242,247] . \mathrm{Pb}^{2+}$ ions usually occur in paddy soil solution and can enter paddy plants through the translocating water uptake (Fig. 2d). In paddy plants, root cell $\mathrm{H}+$ ATPase and $\mathrm{H}+$ drivers can directly take up $\mathrm{Pb}$.

Furthermore, the transpiration process also plays a significant role in pulling or pushing $\mathrm{Pb}^{2+}$ from root cells to shoots through the xylem and from the shoots to leaf cells through vascular flow; $\mathrm{Pb}$ translocation to paddy rice grains is still not well defined [214]. ZIP family transporters such as IRT1, ZRT1, and ZRT2 facilitate the uptake, translocation, and accumulation of different cations, such as $\mathrm{Zn}^{2+}, \mathrm{Mn}^{2+}, \mathrm{Cd}^{2+}, \& \mathrm{Ni}^{2+}$, in paddy systems (Fig. 2 e, f \& g) [248, 249]. Furthermore, the Arabidopsis proteins ZIP1 and ZIP2 transporterlike (AtZIP1 \& AtZIP2) are generally involved in the translocation of both $\mathrm{Mn}$ and $\mathrm{Zn}$ from the root to the shoot. They may also play a significant role in the process of remobilization and distribution at the cellular level [250, 251].

Another family of trace metal transporter-like natural resistance-associated macrophage proteins (NRAMPs) is expressed in paddy plant roots and shoots, and these transporters are involved in the transport of several trace metals, such as $\mathrm{Ni}^{2+}, \mathrm{Mn}^{2+}, \mathrm{Zn}^{2+}, \mathrm{Cd}^{+2}, \mathrm{Cu}^{2+}$, $\& \mathrm{Co}^{2+}$ across paddy plant cell membranes $[49,252,253]$. However, given the availability 
of $\mathrm{Cr}$ and its species, such as $\mathrm{Cr}(\mathrm{III})$ and $\mathrm{Cr}(\mathrm{VI})$, in the paddy soil system, paddy plants have an affinity for translocating and accumulating both, while the mechanism of Cr uptake in the paddy soil-rice system is still unclear. Generally, $\mathrm{Cr}$ is taken up by plants via specific transporters for the absorption of the essential trace metal ions that are required for plant metabolic activity.

$\mathrm{Cr}(\mathrm{III})$ uptake in plant systems occurs through passive mechanisms, and $\mathrm{Cr}(\mathrm{VI})$ uptake occurs through active processes, usually via phosphate or sulfate transporters (Fig. $2 \mathrm{~h}$ ), due to the structural similarity of $\mathrm{Cr}(\mathrm{VI})$ to phosphate and sulfate [254]. However, the uptake, translocation and accumulation mechanisms of trace metals such as $\mathrm{U}, \mathrm{Tl}, \mathrm{Rb}$, and $\mathrm{Sr}$ are still unclear.

\section{Fig. 2.}

\section{Status of trace element contamination in paddy soil-rice systems and risks to rice- growing countries}

Paddy crops show substantial tolerance of trace element toxicity; however, trace metal accumulation in different plant parts, i.e., the roots, shoots, leaves, and grains of paddy plants, in varying concentrations has been reported [255, 256]. From this perspective, field investigations are particularly significant, as the findings of such studies could be efficiently used to measure the status of trace element contamination and accumulation in paddy systems [2].

China is a leading rice-growing country in the world. Trace elements resulting from various human activities contaminate approximately 20 million $\mathrm{h}$ in China, which covers $20 \%$ of the total agricultural area. Paddy cultivation is concentrated in southern China, which also has a highly developed economy and dispersed common nonferrous trace metals, which may seep with nonferrous trace metals into paddy soil systems [2]. Thus, trace metal contamination in paddy soil-rice systems has become a severe concern in China [3].

A study was conducted on paddy soils from Fenghuang, Shimen, and Xiangtan in Hunan Province, China. The mean value of $\mathrm{Cd}$ in the paddy soils was five times higher than the WHO permissible limits for $\mathrm{Cd}(0.35 \mathrm{mg} / \mathrm{kg})$, whereas the maximum $\mathrm{Pb}, \mathrm{Ni}$, and $\mathrm{As}(48.7$, $262 \& 45.2 \mathrm{mg} / \mathrm{kg}$ ) concentrations were higher than the permissible limits $(35,50, \& 10$, respectively) (Table 2). Paddy soil pollution was mainly associated with anthropogenic 
activities such as fertilizer and pesticide application during agricultural production. Consistent with the paddy soil results, the mean value of $\mathrm{Cd}$ in rice grains from Fenghuang, Shimen, and Xiangtan $(0.28,0.32, \& 0.34 \mathrm{mg} / \mathrm{kg}$, respectively) (Table 3$)$ exceeded the national permissible limits $(0.2 \mathrm{mg} / \mathrm{kg})$, whereas the levels of $\mathrm{As}, \mathrm{Ni}, \mathrm{Pb}$, and $\mathrm{Mn}$ contamination in rice grains with the average values of the transfer factors (TFs) for $\mathrm{Cd}$, $\mathrm{Cr}, \mathrm{As}, \mathrm{Ni}, \mathrm{Pb}, \& \mathrm{Mn}$ decreased in the order of $\mathrm{Cd}>\mathrm{Mn}>\mathrm{As}>\mathrm{Ni}>\mathrm{Cr}>\mathrm{Pb} . \mathrm{Cd}$ had the highest TF of 0.55 in rice grains, confirming the $81.2 \%$ increase in cancer risk in the population of Hunan Province, China, which is mainly attributed to the consumption of Cd-contaminated rice [257].

Recently, a similar study conducted in the industrial and urban areas of Hunan Province reported that the mean concentrations of $\mathrm{Cd}, \mathrm{Pb}$, and $\mathrm{As}$ in paddy soil systems were 1.08 , 52.8 , and $19.5 \mathrm{mg} / \mathrm{kg}$, respectively, and $68.9 \%$ of rice grain samples exceeded the permissible limit for $\mathrm{Cd}$ concentration in rice grains (Fig. 3). The maximum $\mathrm{TFs}$ of $\mathrm{Pb}, \mathrm{As}$, and $\mathrm{Cd}$ from paddy soil to rice grains were reported as $0.023,0.044, \& 4.13$, respectively, and the cancer risk of the studied metals in rice grains followed the order $\mathrm{Cd}>\mathrm{As}>\mathrm{Pb}$; these metals pose a serious health risk to the population [4]. In a study conducted by Zeng et al. (2011), paddy soil and rice samples collected from three major rice-growing areas (Tongxiang, Nanhu, \& Xiaoshan) in Zhejiang Province, China, reported that significant correlations between the trace metal contents in paddy soils and rice plants were only observed in $\mathrm{Mn}$ and $\mathrm{Cu}$ in rice shoots and $\mathrm{Zn}$ and $\mathrm{Mn}$ in rice grains, concluding that the trace metal concentrations in the paddy soil-rice system were not acceptable [258].

In Zhengzhou City, China, a field experiment conducted by Liu et al. (2007) evaluated the uptake and translocation of $\mathrm{As}, \mathrm{Cd}, \mathrm{Cr}$, and $\mathrm{Pb}$ in parts of paddy plants and found the accumulation of trace metals in rice grains to be comparatively lower than that in roots and shoots. They confirmed that the levels of $\mathrm{As}, \mathrm{Cd}, \mathrm{Cr}$, and $\mathrm{Pb}$ in the edible rice grains were much lower than the Chinese national limits for food; therefore, no threat to human health in terms of trace metal toxicity was involved with consuming the rice [259].

In contrast with this study, Luo et al. (2012) studied the effect of agronomic practices on trace metals in soils and vegetation mainly in the water conservation area along the East Dongjiang River, South China, and found that $\mathrm{Cd}$ and $\mathrm{Pb}$ concentrations in rice grain were much higher than the Chinese national limits for food; hence, they identified a potential 
human health risk mainly associated with the long-term consumption of contaminated rice [260]. According to their study, which covered an area of approximately $13,600 \mathrm{~km}^{2}$ in Heyuan, Huizhou, Guangzhou, and Dongguan, they further suggested that the average Cd concentrations in paddy soils also exceeded the Chinese national maximum permissible limits [2].

Paddy soils adjacent to a coal mine in Guizhou Province, China, were found to contain higher concentrations of As $(83 \mathrm{mg} / \mathrm{kg})$. In rice plants in the same area, As concentrations ranged from 6.3 to $44.7 \mathrm{mg} / \mathrm{kg}$ in the roots, from 2.2 to $8.9 \mathrm{mg} / \mathrm{kg}$ in the shoots, and from 0.3 to $1.7 \mathrm{mg} / \mathrm{kg}$ in rice grains, with an average As concentration of $0.8 \mathrm{mg} / \mathrm{kg}$ [261]. The distribution and translocation of Se in a paddy soil-rice system was assessed by Sun et al. (2010) in Enshi, Hubei Province, which is typical of Se-rich areas in China. The reported concentration of $\mathrm{Se}$ in paddy soils ranged from 0.5 to $47.7 \mathrm{mg} / \mathrm{kg}$, whereas the $\mathrm{Se}$ concentration in the rice bran was 1.94 times higher than that in the polished rice grains. The total Se concentrations in the paddy plant parts were found in the order straw > bran > whole-grain > polished rice > husk and exceeded the Chinese national maximum permissible limits for Se in rice $(0.3 \mathrm{mg} / \mathrm{kg})$ [262]. In contrast, in paddy fields near an old in Tan Long, Vietnam, Dang et al. (2008) reported high concentrations of trace elements, such as $\mathrm{Cd}$, ranging from 2.3 to $42.9 \mathrm{mg} / \mathrm{kg}$, and $\mathrm{Pb}$, ranging from 1271 to $3953 \mathrm{mg} / \mathrm{kg}$. In Chi Dao, Vietnam, paddy fields situated less than $20 \mathrm{~m}$ away from smelters were found to have total $\mathrm{Pb}$ and $\mathrm{Cd}$ contents ranging from 2000 to 10000 and 2.5 to $56.5 \mathrm{mg} / \mathrm{kg}$, respectively [101].

Due to the increased population and industrialization, Japanese paddy fields suffer from severe paddy soil contamination by trace metals $[2,263]$. In Japan, metal contamination in paddy soils is primarily attributed to wastewater from mines that is used for irrigation purposes and uncontrolled nonferrous emissions from metal refining plants [264]. According to Makino et al. (2010), the total concentrations of trace metals such as $\mathrm{Zn}, \mathrm{Cr}$, $\mathrm{Ni}, \mathrm{Cd}$, and $\mathrm{Pb}(99.0, .64 .0,39.0,0.45, \& 29.0 \mathrm{mg} / \mathrm{kg}$, respectively) in the paddy soil system were significantly elevated compared with the natural concentrations (89.0, 58.0, 26.0, 0.3 \& $24.0 \mathrm{mg} / \mathrm{kg}$, respectively). Consequently, an elevated level of Cd in the paddy soil-rice system has been frequently reported, and it is recognized that rice is a significant source of human Cd intake in Japan $[265,266]$. 
The Cd concentration in Japanese rice has been found to range from 0.02 to $1.06 \mathrm{mg} / \mathrm{kg}$ [267]. The average nutritional consumption of $\mathrm{Cd}$ by the Japanese population is approximately $3.0 \mu \mathrm{g} \mathrm{Cd} / \mathrm{kg}$ body weight/week, which exceeds the acceptable weekly consumption $(2.5 \mu \mathrm{g} \mathrm{Cd} / \mathrm{kg}$ body weight/week) defined by the European Food Safety Authority (EFSA) [242].

A study conducted by Tsukada et al. (2007) in Aomori Prefecture, Japan, reported the status of trace element contamination in a paddy soil-rice pf. He used the paddy soil-topaddy plant TF and suggested that the TFs for all investigated trace elements, excluding $\mathrm{Pb}$, were within two orders of magnitude. According to Yap et al. (2009), a study conducted in Kota Marudu, Malaysia reported that trace metals such as $\mathrm{Cd}, \mathrm{Cr}, \mathrm{Mn}, \mathrm{Zn}, \mathrm{Cu}, \& \mathrm{~Pb}$ can accumulate in different parts of the paddy plant, furthermore suggesting that the concentrations of investigated trace elements in rice grains were below the maximum permissible limits specified by the Malaysian Food Act and Food Regulations.

In western Bangkok, Thailand, a study conducted by Chinoim and Sinbuathong (2010) examined the status of trace metal $(\mathrm{Cr}, \mathrm{Cd}, \mathrm{Ni}, \mathrm{Pb}, \mathrm{Zn}, \& \mathrm{Cu})$ contamination in paddy soils and reported that the concentrations of the studied trace metals were much lower than the acceptable limits. In contrast, Shraim (2017) studied the status of trace metals in marketpurchased Thai rice and reported $\mathrm{Cd}$ and $\mathrm{Pb}$ concentrations that exceeded acceptable limits. A study conducted by Jo and Koh (2004) on approximately 4047 paddy soil samples collected from different locations in Korea reported that the status of trace metal contamination $(\mathrm{Zn}, \mathrm{Pb}, \mathrm{Cd}, \& \mathrm{Cu}$ ) ranged from 0.1 to $96.7,0.01$ to $66.4,0.1$ to 1.01 , and 0.1 to $41.6 \mathrm{mg} / \mathrm{kg}$, respectively.

A recent study conducted by Kwon et al. (2017) in a paddy soil-rice system adjacent to four mining areas (Dalsung mine, Yeongdae mine, Sambo mine, and Munmyung mine) in Korea reported that the average concentrations of $\mathrm{Cd}, \mathrm{Cu}, \mathrm{Pb}, \mathrm{Zn}$, and $\mathrm{As}$ in paddy soils and grains were comparatively higher than the worldwide acceptable limits defined by numerous researchers (Table $1 \&$ Table 2). Furthermore, an acceptable daily intake (ADI) of $\mathrm{As}$ and $\mathrm{Cd}$ in rice grains of up to $50 \%$ and $80 \%$, respectively, is recommended by the Joint Food Additive and Contaminants Committee and the World Health Organization (FAO \& WHO), respectively. Consequently, the regular consumption of contaminated rice from these mining areas can lead to severe human health problems in the local population. 
In Iran, a review on the status of trace element contamination ( $\mathrm{As}, \mathrm{Cr}, \mathrm{Pb}, \mathrm{Cd}, \& \mathrm{Ni}$ ) in rice grains and an assessment of the associated human health risks noted that the trace metal concentrations were highest in rice grains from northern areas of Iran, primarily Mazandaran \& Gillan provinces [268]. Furthermore, minimum and maximum levels for trace metals (As \& Ni) were established in Iran, and the ranked order of trace metals by their total hazard quotient (THQ) in the human health risk assessment was $\mathrm{As}>\mathrm{Cr}>\mathrm{Pb}>\mathrm{Cd}>\mathrm{Ni}[268]$.

In Bangladesh, a study conducted by Ahsan et al. (2009) stated the current scenario for contamination by As and other trace metals in the floodplain agricultural field of the Faridpur and Dhamrai study areas. This study reported that the average As concentration in the Faridpur soil system exceeded the WHO acceptable limits $(10 \mathrm{mg} / \mathrm{kg})$ by three times, whereas the average levels of other trace metals $(\mathrm{Cr}, \mathrm{Co}, \& \mathrm{Cu})$ in both study areas also exceeded the WHO acceptable limits $(70,8, \& 30 \mathrm{mg} / \mathrm{kg}$, respectively); however, the Se concentration was much lower than the WHO acceptable limit $(0.7 \mathrm{mg} / \mathrm{kg})$. Furthermore, in both study areas, the groundwater contaminated with As and other trace metals also led to elevated concentrations of these trace metals in soils because of the predominant use of irrigation with the polluted groundwater [269].

According to a survey across Bangladesh, As and other trace elements in paddy soil systems were elevated in areas where shallow tube wells had operated for a long time [270]. However, microlevel studies in different villages of Chakdaha, Nadia, West Bengal, India, were conducted and confirmed the transference of As from irrigation water to the paddy soil-rice system [271]. The results showed that the As concentration in the irrigation water ranged from 0.1 to $0.8 \mathrm{mg} / \mathrm{L}$, which significantly exceeded the WHO acceptable limit $(0.01$ $\mathrm{mg} / \mathrm{L}$ ) for drinking and irrigation water; in the paddy soils, the reported As concentration was below the WHO acceptable limit $(10 \mathrm{mg} / \mathrm{kg})$. In rice plants, the maximum accumulation in roots ranged from 7.2 to $18.6 \mathrm{mg} / \mathrm{kg}$, and the lowest accumulation, in the rice grains, ranged from 0.25 to $0.7 \mathrm{mg} / \mathrm{kg}[2,271]$. A recent study conducted by Yadav et al. (2017) in the Fatehabad district, Haryana, India, suggested that trace metals $(\mathrm{Cu}, \mathrm{Co}, \&$ $\mathrm{Zn)}$ were abundant in rice grains as essential trace nutrients, and human health risk indices revealed that residents in most of the studied locations were safe. In Shakargarh, Pakistan, 
a study conducted by Tariq and Rashid (2012) reported $\mathrm{Pb}$ accumulation in rice grains, which may cause several health problems for the residents of the studied location. Rahman et al. (2014) performed a comparative study of Australia-grown rice with marketpurchased rice from India, Bangladesh, Pakistan, Canada, Italy, Thailand, and Vietnam from Asian shops in Sydney. Based on the results for $\mathrm{Cu}$ and $\mathrm{Ni}$ concentrations in Vietnamese rice and those for $\mathrm{Cu}, \mathrm{Ni}, \mathrm{Cd}, \mathrm{Pb}, \& \mathrm{Cr}$ in Thai rice for sale in Australia, the metal concentrations exceeded those in the Australia-grown rice, whereas the trace metal concentrations in the Pakistani rice on sale in Australia were significantly lower than those in the Australia-grown rice.

\section{Fig. 3.}

Table 1

Table 2

\section{Trace element accumulation influences in paddy soil-rice systems}

Trace element accumulation in paddy systems is determined by several influences, such as the bioavailability of the metals, the physicochemical properties of the paddy soil, and the plant species of interest [272]. According to Zhao et al. (2010), trace element enrichment in paddy plants is significantly correlated with the soil physicochemical properties, such as the soil $\mathrm{pH}$ and the soil organic matter $(\mathrm{OM})$. However, the $\mathrm{Cu}$ accumulation in paddy plants showed a weak correlation with soil physicochemical properties, particularly the soil $\mathrm{pH}$, and there was no correlation between the accumulation of $\mathrm{Cu}$ and $\mathrm{OM}$. This suggests that other unknown factors could influence $\mathrm{Cu}$ accumulation in plants. A study conducted in the southern part of the Yangtze delta studied $\mathrm{Cu}$ contamination in the paddy soil-rice system, where $\mathrm{Cu}$-rich contaminated wastewater is primarily used for irrigation purposes [273]. Their results found a strong correlation between trace element concentrations in the soil and in rice grains, and the total $\mathrm{Cu}$ concentrations in the paddy soil, brown rice, rice hulls, and shoots were 101.2, 15.5, 133.2, and $101.4 \mathrm{mg} / \mathrm{kg}$, respectively. Thus, strong correlations between the $\mathrm{Cu}$ concentration in rice shoots and rice hulls and the $\mathrm{Cu}$ concentration in the soil were proposed, with values of $r=0.92 \& 0.83$, respectively [273].

According to Tariq and Rashid (2012), the trace element concentrations in paddy soil are significantly correlated with plant uptake but insignificantly correlated with the 
physicochemical properties of paddy soils and the plant species. Therefore, through plant rhizosphere processes, trace element uptake is generally governed by the physicochemical properties of paddy soil. According to them, the paddy soil $\mathrm{pH}$ was strongly negatively but insignificantly correlated with the paddy soil levels of $\mathrm{Co}, \mathrm{Pb}$, and $\mathrm{Cr}$, with values of $\mathrm{r}=$ $0.49,-0.41 \&-0.48$, respectively, whereas sulfate $\left(\mathrm{SO}_{4}{ }^{2-}\right)$ was found in the paddy soils. However, the $\mathrm{SO}_{4}{ }^{2-}$ content of the soil was strongly positively and significantly correlated with the $\mathrm{Co}, \mathrm{Pb}$, and $\mathrm{Cr}$ concentrations. Furthermore, significant positive correlations between pairs of trace elements in paddy soils, such as $\mathrm{Pb}$ and $\mathrm{Cr}, \mathrm{Cd}$ and $\mathrm{Pb}, \mathrm{Pb}$ and $\mathrm{Co}$, and $\mathrm{Cr}$ and $\mathrm{Co}$, and strong negative correlations between $\mathrm{Ni}$ and $\mathrm{Cd}$ as well as $\mathrm{Pb}$ and $\mathrm{Ni}$ were also reported. Nevertheless, within the plant parts or the grain, the relationships between trace elements were reported to be dissimilar from those in the paddy soil.

In Mae Sot, Tak, Thailand, no significant correlation was observed between the $\mathrm{Cd}$ concentration in paddy soil and that in rice grains, with $r=0.117$ [274]. Additionally, in ewaste recycling areas in Southeast China, no strong significant correlation was observed between trace element concentrations in paddy soils and rice grains; furthermore, the investigators claimed that uptake may significantly contribute to $\mathrm{Cd}, \mathrm{Zn}, \& \mathrm{~Pb}$ levels, while $\mathrm{Cu}$ and $\mathrm{Cr}$ levels were primarily influenced by the roots [117]. In Table 3, trace element translocation in the paddy soil-rice system (from the paddy soil to the paddy plant roots, shoots, and rice grains) is expressed via translocation factors (TFs) previously described by $[2,275]$. The TF from the paddy soil to the grain $\left(\mathrm{TF}_{\text {grain/soil }}\right)$ was $<1$ for all trace elements listed; nevertheless, a particularly high TF from the paddy soil to the root $\left(\mathrm{TF}_{\text {root/soil }}\right)$ is often shown [2].

Trace elements such as $\mathrm{Cd}, \mathrm{Zn}, \& \mathrm{~Pb}$ and their particle size and mobility might be the significant reason for the maximum foliar and plant root uptake [276]. It has been stated that the particle sizes of vehicle traffic-related elements such as $\mathrm{Cd}$ and $\mathrm{Pb}$ are usually fine, $\mathrm{Cu}$ and $\mathrm{Zn}$ are usually medium, and $\mathrm{Cr}$ is found in in coarse particles; $\mathrm{Zn}$ is more mobile than $\mathrm{Cu}[2]$. It has also been reported that $\mathrm{Cd}, \mathrm{Zn}$, and $\mathrm{Pb}$ particles emitted from vehicles have a higher leaf penetration capacity than those of $\mathrm{Cu}$ and $\mathrm{Cr}$ [277]. Upon foliar $\mathrm{Cd}$ and $\mathrm{Pb}$ absorption, these metals might move to existing paddy plant growth areas, such as rice grains [2]. Thus, studies have suggested that trace element levels in rice grains not only depend on the physicochemical properties and available metal concentrations in the paddy 
soil system but also on vehicle emissions, the metal particle size, metal mobility, and metal penetration capability, which are significant factors if rice is grown adjacent to highways [2].

Table 3

\section{Trace element-contaminated soil management/remediation methods}

Once trace elements are released into the environment, they persist for an extended time period that varies depending on the amount and type of the trace element and the soil [10]. Several soil clean-up processes, such as physical, chemical, phytoremediation, and microbial remediation methods, are widely used in the remediation of trace elements. These methods can be performed in situ (on-site) or ex situ (off-site) (Fig. 4). These bioremediation methods are mostly used in combination for the cost-efficient and effective clean-up of trace element polluted sites [24].

\subsection{Physical methods}

Physical soil clean-up methods can be further classified into soil replacement, soil isolation, soil vitrification, and electrokinetic methods $[24,278]$. In the soil replacement method, the polluted soil is replaced or partially replaced with non-contaminated soil [24]. Before 1984, excavation, ex situ/off-site disposal, and soil replacement were the most common methods used for cleaning up contaminated sites [279]. Soil replacement dilutes the concentration of trace elements and, in turn, increases soil functionality [10]. In this method, the replaced soil is usually treated to remove trace elements or, in some cases, might be dumped at another site. The soil replacement method is generally carried out in one of two ways: digging the soil or importing new (uncontaminated) soil [280]. In the digging method, the contaminated site is deeply excavated, and the trace elements are spread into the deeper places in the site. The trace elements are thereby diluted. The importing method refers to the addition of new, clean soil into the contaminated soil. The new clean soil might be used to covered the site surface or might be mixed in to decrease the levels of trace elements [281, 282].

The soil isolation method refers to separating trace metal-polluted soil from uncontaminated soil; nonetheless, for complete remediation, another auxiliary engineering method is needed $[283,284]$. The soil isolation method is usually designed to stop the offsite movement of trace elements by limiting them to within a specified zone [10, 285]. In 
soil, the isolation method is generally used to avoid further contamination of groundwater through trace elements after other remediation methods are not economically or physically possible [24]. However, in some cases, the polluted zones can be isolated provisionally to prevent transportation during site evaluation and remediation [279]. In this method, the subsurface barriers/walls are typically applied to restrict polluted water and the soil by limiting the flow of both surface and groundwater in a contaminated site [286].

In soil vitrification, the movement of trace elements inside the soil system is decreased through high-temperature action in highly contaminated sites, which leads to the formation of vitreous substances [287]. In the soil vitrification method, some trace elements such as $\mathrm{Hg}$ can be volatilized under high-temperature conditions; therefore, they must be collected for additional disposal and/or further treatment [288]. The soil vitrification method is not considered a conventional trace element remediation method because the soil vitrification technique is relatively effortless to apply compared to other physical clean-up methods. Soil vitrification might be functional for most soils, which are polluted with both inorganic and organic pollutants [279]. Throughout the in situ soil vitrification method, an electrical current is passed through the soil by vertically inserting an array of electrodes into the polluted zone [289].

In contrast, the electrokinetic physical soil clean-up method is cost-effective and extensively used for the removal of trace elements from contaminated soils [290]. The soil electrokinetic process generally operates based on the electric field gradient principle with an appropriate power intensity and is typically applied to two sides of an electrolytic tank comprising saturated polluted soils [291]. Trace elements that are present in the soil system can be separated through electrophoresis, electromigration, or electroseepage, which decreases the contamination level of the contaminated site [287].

\subsection{Chemical methods}

Chemical-based soil clean-up methods can be further characterized as soil immobilization, soil encapsulation, and soil washing [24]. The soil immobilization method refers to a reduction in trace element mobility, bioavailability, and bioaccessibility in the soil by adding immobilization agents to the polluted soil sites. In soil, trace elements are immobilized by several reactions, such as adsorption, complexation, and precipitation [111]. These immobilization reactions cause the redistribution of trace elements from the 
soil solution into solid particles, therefore reducing their movement and bioavailability in polluted soil. Trace element immobilization in the soil is mostly carried out by using inorganic and organic amendments to soils [292]. Common amendments to soils include microbes, phosphates, zeolites, cement, clays, minerals, and organic amendments [279]. Recently, several studies suggested that low-cost industrial residues, including industrial eggshells, red mud, and termitaries, could also be used for the immobilization of trace elements in contaminated soil [279, 293, 294] Currently, biomaterials are extensively used to immobilize trace elements in soils due to their availability and very low cost [295]. Of the biomaterials, the extensive application of biochar has received important consideration for immobilizing trace elements in the soil [296].

The soil encapsulation method differs from the other methods and is mostly used as a process to filter contaminants from soils; the encapsulation stops them from spreading further [286]. Soil encapsulation remediation also involves the mixing of polluted soils with different products, such as concrete, lime, and asphalt. [10, 279]. In the encapsulation method, the toxic element-contaminated soil becomes immobile and therefore stops the spreading of pollution to surrounding resources [297]. Several binding materials are used in the formation of the solid blocks; cement is the ideal material due to its high availability, adaptability, and cost-effectiveness [10, 279].

The soil washing method refers to the removal of trace elements from contaminated soils by using different reagents and extractants that can leach trace elements from the soil. It is done on physically excavated soils ex situ or in situ [10, 298]. Recently, the application of appropriate extractants for the leaching of trace metals from polluted soils has been confirmed as an excellent alternative to some of the old conventional methods for the removal of toxic elements [10,299]. During the soil washing method, the polluted soil is excavated and mixed with an appropriate extractant solution based on the type of trace elements and soil properties [300].

\subsection{Phytoremediation}

Phytoremediation is a practical remediation method and can rebuild the natural conditions of the soil to remediate harmful or adverse ecological effects [301]. Phytoremediation methods primarily make use of plants to remove contaminants from soils [302]. The phytoremediation method is comparatively efficient, simple, non-invasive, cost- 
effective, and eco-friendly and can provide an enduring solution [303]. Phytoremediation is also known as green remediation, botanoremediation, agroremediation, and/or vegetative remediation and includes methods that generally make use of plants to remediate and revegetate contaminated sites [10]. The term phytoremediation includes several methods and applications that differ significantly in process or mechanisms with plants that might immobilize, remove/clean-up, or degrade toxic trace elements [304]. Based on diverse plant uptake patterns, phytoremediation can include phytostabilization, photoevaporation, and phytoextraction [305]. During phytovolatilization, toxic trace elements are taken up from the soil and transformed into less-toxic vapours and then released into the atmosphere via the plant transpiration process [306].

During the phytovolatilization process, elements are first combined into volatile organic complexes and then released to the ambient environment as biomolecules [307]. Some trace elements, including As, Se, and $\mathrm{Hg}$, may occur as gases in the environment. Several plant species, such as Brassica juncea, Arabidopsis thaliana, and Chara canescens, have the capability to take up these toxic elements from soils and change them into their gaseous forms inside the plant tissues and then release them into the ambient environment. Arsenic and its species $\mathrm{As}(\mathrm{V})$ and $\mathrm{As}(\mathrm{III})$ were effectively volatilized from the leaves of Pteris vittata plants. Arabidopsis thaliana and Brassica juncea can be cultivated under elevated Se levels and are proficient in volatilizing Se [279].

Phytostabilization is well defined as the use of plants to decrease the availability and movement of toxic elements in soils because of their stabilization by plants [308]. Phytostabilization may not reduce the levels of toxic elements that exist in polluted soil but prevents their off-site mobilization [309]. The primary purpose of phytostabilization is to limit trace elements in the vadose zone of plants by accumulation through roots and/or precipitation inside the rhizosphere zone $[310,311]$. Thus, of the different phytoremediation methods, phytostabilization does not remediate or remove toxic elements from soli but decreases the mobilization of toxic elements to adjacent media/sites [309]. In addition, phytostabilization may also be applied at contaminated sites where practical/controlling limits interfere with the selection and application of the most suitable clean-up methods [312]. Several plant species, for instance, Agrostis spp., and Festuca spp. 
are widely applied for the phytostabilization of $\mathrm{Cu}-, \mathrm{Pb}-$, and $\mathrm{Zn}$-contaminated soils in Europe [313].

Phytoextraction is an efficient method for the removal of toxic elements from contaminated soils through plant uptake mechanisms [314]. This solar-driven method is generally based on the ability of plant roots to take up and translocate levels of toxic elements from the soil to the above-ground plant parts [315]. Therefore, phytoextraction reduces the contaminated soil mass [316] and efficiently translocates toxic elements from the soil to aerial plant parts [317]. Compared with contaminated soil, plant biomass is generally easy to recycle, transfer, and treat/oxidize, and this method ensures the a permanent removal of toxic elements from soils [309]. Nevertheless, the phytoextraction method is more convenient for those sites that are contaminated by low-to-moderate levels of toxic elements because several plant species may not be able to survive in highly contaminated sites [309, 318]. For instance, the phytoextraction method is very efficient for $\mathrm{Pb}$ removal with Brassica juncea in soils whose $\mathrm{Pb}$ concentration is less than 1500 $\mathrm{mg} / \mathrm{kg}$ [279].

Typically, plant species that are efficiently used for phytoextraction must have 1) high toxic element accumulation ability in their aerial parts, 2) high tolerance to levels of toxic elements, 3 ) high capability to grow quickly with maximum biomass, and 4) very profuse root systems; so far, no standard has been suggested for hyperaccumulator plants [279]. However, hyperaccumulator plant species can accumulate 100- to 500-fold more toxic elements in their shoot tissues than non-accumulator plants without any effect on yield [279, 319]. Typically, most hyperaccumulator plant species can accumulate or tolerate only a single specific toxic element [320], while fewer plant species have the ability to accumulate and tolerate more than one element; these plants are known as multielement hyperaccumulator plant species [321]. Examples include Thlaspi caerulescens, which hyperaccumulates $\mathrm{Pb}, \mathrm{Zn}, \mathrm{Cd}$, and $\mathrm{Ni}$ [315]; Thlaspi goesingense and Thlaspi ochroleucum can hyperaccumulate $\mathrm{Ni}$ and $\mathrm{Zn}$; and Thlaspi rotundifolium efficiently hyperaccumulates $\mathrm{Pb}, \mathrm{Zn}$, and $\mathrm{Ni}[279]$.

Phytoextraction efficiency is increased through genetic modification of plants [322]. It has been suggested that several genes play a crucial role in toxic element uptake, translocation, and sequestration in the vacuole in plant tissues [323]. Primarily, the 
application of a gene in specific plant species typically depends on the objective of plant mutation [324]. In phytoextraction processes, enhanced uptake with an increased translocation of elements towards the plant's aerial parts [309] can be accomplished through genetically modified genes that are mainly responsible for enhancing element adsorption in plant root cells, decreasing plant root element sequestration, increasing element xylem loading, and increasing translocation to plant shoots for storage in epidermal and mesophyll cells [279]. To date, numerous key processes have been reported at the molecular level, signifying the possibility of engineering toxic element hyperaccumulation in plant systems [325]. The multifold enhancement in absorption, xylem loading, and translocation to aerial shoots increases the tolerance reported in genetically modified plants compared to that in wild types [279] for some toxic elements, such as $\mathrm{As}, \mathrm{Zn}, \mathrm{Pb}$, and $\mathrm{Cd}$, in Arabidopsis thaliana, Lactuca sativa, Brassica oleracea, Nicotiana glauca, and N. tabacum, respectively [326-329].

\subsection{Microbial remediation}

Microbial remediation primarily refers to the application of microorganisms to promote the precipitation, adsorption, and oxidation-reduction of trace elements in the soil. Under toxic metal stress conditions, soil microbial associations aid in increasing plant growth [330]. Several studies have reported that plant growth-promoting and toxic element resistance and soil microorganisms might also protect plants from element toxicity and/or even increase element uptake in hyperaccumulator plants [331]. Microorganism-based remediation methods for toxic elements involve numerous mechanisms, including bioleaching, biomineralization, biosorption, enzyme-catalysed transformation, intracellular accumulation, and oxidation-reduction reactions [279]. Toxic elementresistant rhizobacteria are able to stimulate plant growth and element accumulation in plants by the production of different chemicals, such as indole acetic acid (IAA) and monocyclopropane-1-carboxylate (ACC) [332]. Furthermore, element-resistant rhizobacteria increase the element tolerance of host plants by inducing thiol complexes, metallothionein, and/or superoxide dismutase [279, 333]. Application of Burkholderia sp. (Z-90) increased toxic element clean-up efficiency in the soil by $24 \%, 31 \%, 32 \%, 37 \%$, 44\%, and 52\% for $\mathrm{Cu}, \mathrm{Pb}, \mathrm{As}, \mathrm{Cd}, \mathrm{Zn}$, and $\mathrm{Mn}$, respectively [334]. Bacillus sp. (E1S2) significantly enhanced the uptake of $\mathrm{Zn}(18 \%)$ and Cd (43\%) by Sedum plumbizincicola 
[335]. In addition, microbial associations may also cause numerous positive effects for plant growth, including osmotic adjustment, stomatal regulation, and increased mineral uptake [336]. Soil bacterial associations may also increase the mobility and availability of the elements in soils in numerous ways, including decreasing the soil $\mathrm{pH}$, facilitating plantgrowth [337], and chelating complexes (organic acids, biosurfactants, and siderophores) through changing the soil oxidation-reduction conditions [279]. Nevertheless, the influence of soil microorganisms on element solubility and plant uptake may not be consistent [338]. Soil microorganisms might increase or decrease element uptake by plants [339]. Indeed, specific microbial methods can increase element solubility and bioaccumulation; however, numerous other methods may cause element immobilization, therefore reducing their phytouptake [279, 331].

Additionally, several other important factors that influence the selection and applicability of the existing soil remediation processes include the total cost involved, time required, efficiency under elevated toxic element contamination, acceptance and availability, longterm effectiveness, and applicability to multi-element contaminated sites; these factors are discussed in detail in Table S3 [279].

Fig. 4.

Table 4

\section{Conclusion and future research perspectives}

In this review, we summarize the basic chemical behaviours, transport, endpoints, and significant natural and anthropogenic sources of trace elements, including $\mathrm{As}, \mathrm{Se}, \mathrm{Cd}, \mathrm{Pb}$, $\mathrm{Zn}, \mathrm{Mn}, \mathrm{Ni}$, and $\mathrm{Cr}$, in the soil system as well as their uptake, translocation, and accumulation mechanisms in the paddy soil-rice system. Human health effects are significantly associated with these toxic and potentially toxic metals not only due to their occurrence in the environment but also in their uptake, translocation, and accumulation via different transporters, such as As (silicate ( $\mathrm{Si}$ ), phosphate (Pi)), Se (sulfate (ST)), Cr (Pi or ST), Zn (AtZIP1 or NRAMP), Mn (NRAMP5 or AtZIP1), Ni (NRAMP), and Cd (NRAMP5, OsIRT1, or osHMA2), in rice systems.

Moreover, the contamination status of paddy soil-rice systems in major rice-growing countries, including India, Bangladesh, China, Pakistan, Malaysia, Thailand, Japan, and Australia, was presented. Consequently, it is worth comparing the existing research 
conclusions on the elevated concentrations of trace elements in rice grain in different countries: Se, As, and Zn (0.02-9.7, 3.1-14, \& 2.3-484.9), Cd, and Pb (9.4-178, \& 0.061529), Cr (41-217), and Ni (61-356) in China, India, Bangladesh, and Australia, respectively.

This review also provides an inventory of the various research studies on trace metal concentrations from multiple identified and unidentified contamination sources, mainly in paddy soil-rice systems in rice-growing countries. In the future, this study will be helpful for paddy rice farmers and decisionmakers at regional, national, and international levels to support various administrative policies. The bio-geochemical conditions associated with paddy farming, such as the frequent alternation between wet and dehydrated environments and the oxygenated-non oxygenated paddy soils, make paddy rice systems favourable for trace metal accumulation.

The various influences associated with the accumulation of these metals in the paddy soil-rice system could be 1) the paddy soil-rice plant characteristics, 2) the various soil physico-chemical indicators associated with uptake, translocation, and accumulation, and 3) the post-crop management practices. These mechanisms are primarily reliant on the cultivar (product class), the environmental conditions, and the administrative policies. Accordingly, multidisciplinary elementary and practical research efforts are essential to mitigate trace metal accumulation in paddy soil-rice systems and prevent toxicity to humans from rice.

The contents of the current review highlight the need for a wide-ranging, extensive, periodic monitoring of the contamination status of paddy soil-rice system regions. Broad awareness of paddy soil contamination and the associated health risks might lead different countries to establish strict legal guidelines and rules for paddy soil contamination and to adopt consistent remediation measures to control trace element sources and translocation in paddy soil-rice systems.

Therefore, the present study will be helpful for comparing the various trace element mitigation measures and for understanding the status of trace element contamination, categorization, and translocation mechanisms in paddy soil-rice systems. 


\section{Acknowledgments}

This work is supported by National Key Research and Development Program of China (No. 2019 YFC1803600, and No. 2017YFD0800302), the National Science Foundation of China-Project of Karst Science Research Center (U1612442), and Science and Technology program of Guizhou Province [Grant No. (2019)5618/2019(2963)/(2019)4428], and UK Royal Academy of Engineering Frontier Follow-up Grant (FF\1920\1\36). ZY thanks UK NERC Fellowship grant (NE/R013349/2). The authors would also like to thank all anonymous reviewers for their constructive comments that significantly improved the quality of the manuscript.

\section{Conflict of Interest}

The authors declared no conflict of interest.

\section{References}

[1] M.Z. ar Hashmi, A. Varma, Environmental Pollution of Paddy Soils, (2018).

[2] K. Arunakumara, B.C. Walpola, M.-H. Yoon, Current status of heavy metal contamination in Asia's rice lands, Reviews in Environmental Science and Bio/Technology, 12 (2013) 355-377.

[3] K. Zhao, X. Liu, J. Xu, H. Selim, Heavy metal contaminations in a soil-rice system: identification of spatial dependence in relation to soil properties of paddy fields, Journal of Hazardous Materials, 181 (2010) 778-787.

[4] A. Lu, B. Li, J. Li, W. Chen, L. Xu, Heavy metals in paddy soil-rice systems of industrial and township areas from subtropical China: Levels, transfer and health risks, Journal of Geochemical Exploration, 194 (2018) 210-217.

[5] Y. Lu, S. Song, R. Wang, Z. Liu, J. Meng, A.J. Sweetman, A. Jenkins, R.C. Ferrier, H. Li, W. Luo, Impacts of soil and water pollution on food safety and health risks in China, Environment international, 77 (2015) 5-15.

[6] W. Ali, M.W. Aslam, C. Feng, M. Junaid, K. Ali, S. Li, Z. Chen, Z. Yu, A. Rasool, H. Zhang, Unraveling prevalence and public health risks of arsenic, uranium and co-occurring trace metals in groundwater along riverine ecosystem in Sindh and Punjab, Pakistan, Environmental Geochemistry and Health, 41 (2019) 2223-2238. 
[7] S. Garba, M. Abubakar, Source and Distribution of the Heavy Metals: Pb, Cd, Cu, Zn, $\mathrm{Fe}, \mathrm{Cr}$, and $\mathrm{Mn}$ in Soils of Bauchi Metropolis, Nigeria, American Journal of Engineering Research, 7 (2018) 13-23.

[8] B. Olowookere, O. Oyibo, G. Oyerinde, Heavy Metals Concentration in Dumpsites at Gwagwalada, Abuja: Implications on Sustainable Environmental Management, Greener Journal of Soil Science and Plant Nutrition, 5 (2018) 001-004.

[9] X. Liu, Q. Song, Y. Tang, W. Li, J. Xu, J. Wu, F. Wang, P.C. Brookes, Human health risk assessment of heavy metals in soil-vegetable system: a multi-medium analysis, Science of the Total Environment, 463 (2013) 530-540.

[10] R.A. Wuana, F.E. Okieimen, Heavy metals in contaminated soils: a review of sources, chemistry, risks and best available strategies for remediation, Isrn Ecology, 2011 (2011).

[11] J. Rinklebe, V. Antoniadis, S.M. Shaheen, O. Rosche, M. Altermann, Health risk assessment of potentially toxic elements in soils along the Central Elbe River, Germany, Environment international, 126 (2019) 76-88.

[12] R. Nieder, D.K. Benbi, F.X. Reichl, Role of Potentially Toxic Elements in Soils, in: Soil Components and Human Health, Springer, 2018, pp. 375-450.

[13] N. Geng, Y. Wu, M. Zhang, D.C. Tsang, J. Rinklebe, Y. Xia, D. Lu, L. Zhu, K.N. Palansooriya, K.-H. Kim, Bioaccumulation of potentially toxic elements by submerged plants and biofilms: A critical review, Environment international, 131 (2019) 105015.

[14] S. Palaniappan, K. Annadurai, Organic Farming Theory \& Practice, Scientific publishers, 2018.

[15] P.A. Seck, A. Diagne, S. Mohanty, M.C. Wopereis, Crops that feed the world 7: Rice, Food security, 4 (2012) 7-24.

[16] C.P. Timmer, Food Security in A sia and the P acific: The Rapidly Changing Role of Rice, Asia \& the Pacific Policy Studies, 1 (2014) 73-90.

[17] W. Wang, R. Mauleon, Z. Hu, D. Chebotarov, S. Tai, Z. Wu, M. Li, T. Zheng, R.R. Fuentes, F. Zhang, Genomic variation in 3,010 diverse accessions of Asian cultivated rice, Nature, 557 (2018) 43. 
[18] Y. Hu, H. Cheng, S. Tao, The challenges and solutions for cadmium-contaminated rice in China: a critical review, Environment international, 92 (2016) 515-532.

[19] M. Halim, R. Majumder, M. Zaman, Paddy soil heavy metal contamination and uptake in rice plants from the adjacent area of Barapukuria coal mine, northwest Bangladesh, Arabian Journal of Geosciences, 8 (2015) 3391-3401.

[20] V. Antoniadis, S.M. Shaheen, E. Levizou, M. Shahid, N.K. Niazi, M. Vithanage, Y.S. Ok, N. Bolan, J. Rinklebe, A critical prospective analysis of the potential toxicity of trace element regulation limits in soils worldwide: Are they protective concerning health risk assessment?-A review, Environment international, 127 (2019) 819-847.

[21] J. Abraham, K. Dowling, S. Florentine, Assessment of potentially toxic metal contamination in the soils of a legacy mine site in Central Victoria, Australia, Chemosphere, 192 (2018) 122-132.

[22] K.N. Palansooriya, S.M. Shaheen, S.S. Chen, D.C. Tsang, Y. Hashimoto, D. Hou, N.S. Bolan, J. Rinklebe, Y.S. Ok, Soil amendments for immobilization of potentially toxic elements in contaminated soils: A critical review, Environment international, 134 (2020) 105046.

[23] T. Minnikova, T. Denisova, S. Mandzhieva, S. Kolesnikov, T. Minkina, V. Chaplygin, M. Burachevskaya, S. Sushkova, T. Bauer, Assessing the effect of heavy metals from the Novocherkassk power station emissions on the biological activity of soils in the adjacent areas, Journal of Geochemical Exploration, 174 (2017) 70-78.

[24] L. Liu, W. Li, W. Song, M. Guo, Remediation techniques for heavy metalcontaminated soils: principles and applicability, Science of the Total Environment, 633 (2018) 206-219.

[25] F.-J. Zhao, Y. Ma, Y.-G. Zhu, Z. Tang, S.P. McGrath, Soil contamination in China: current status and mitigation strategies, Environmental Science \& Technology, 49 (2014) 750-759.

[26] C. Bini, Geology and geomorphology, in: The Soils of Italy, Springer, 2013, pp. 3956. 
[27] R.E. White, Principles and practice of soil science: the soil as a natural resource, John Wiley \& Sons, 2013.

[28] H. Huot, M.-O. Simonnot, J.L. Morel, Pedogenetic trends in soils formed in technogenic parent materials, Soil Science, 180 (2015) 182-192.

[29] T.T.T. Dung, V. Cappuyns, R. Swennen, N.K. Phung, From geochemical background determination to pollution assessment of heavy metals in sediments and soils, Reviews in Environmental Science and Bio/Technology, 12 (2013) 335353.

[30] T. Chen, X. Liu, M. Zhu, K. Zhao, J. Wu, J. Xu, P. Huang, Identification of trace element sources and associated risk assessment in vegetable soils of the urbanrural transitional area of Hangzhou, China, Environmental pollution, 151 (2008) 67-78.

[31] Z. Jun-Hui, M. Hang, Eco-toxicity and metal contamination of paddy soil in an ewastes recycling area, Journal of Hazardous Materials, 165 (2009) 744-750.

[32] B. Hu, S. Shao, Z. Fu, Y. Li, H. Ni, S. Chen, Y. Zhou, B. Jin, Z. Shi, Identifying heavy metal pollution hot spots in soil-rice systems: A case study in South of Yangtze River Delta, China, Science of the Total Environment, 658 (2019) 614625.

[33] L. Cai, L. Huang, Y. Zhou, Z. Xu, X. Peng, L.a. Yao, Y. Zhou, P.a. Peng, Heavy metal concentrations of agricultural soils and vegetables from Dongguan, Guangdong, Journal of Geographical Sciences, 20 (2010) 121-134.

[34] B.J. Alloway, Sources of heavy metals and metalloids in soils, in: Heavy metals in soils, Springer, 2013, pp. 11-50.

[35] M.S. Islam, M.K. Ahmed, M. Habibullah-Al-Mamun, Apportionment of heavy metals in soil and vegetables and associated health risks assessment, Stochastic environmental research and risk assessment, 30 (2016) 365-377.

[36] S. Khan, S. Rehman, A.Z. Khan, M.A. Khan, M.T. Shah, Soil and vegetables enrichment with heavy metals from geological sources in Gilgit, northern Pakistan, Ecotoxicology and environmental safety, 73 (2010) 1820-1827. 
[37] S. Tariq, Environmental geochemistry of surface and sub surface water and soil in Peshawar basin of NWFP Pakistan, Unpublished PhD thesis, University of Peshawar, (2001).

[38] S. Fendorf, H.A. Michael, A. van Geen, Spatial and temporal variations of groundwater arsenic in South and Southeast Asia, Science, 328 (2010) 1123-1127.

[39] M.A. Rahman, H. Hasegawa, M.M. Rahman, M.A. Rahman, M. Miah, Accumulation of arsenic in tissues of rice plant (Oryza sativa L.) and its distribution in fractions of rice grain, Chemosphere, 69 (2007) 942-948.

[40] M.E. Essington, Soil and water chemistry: an integrative approach, CRC press, 2015.

[41] R. Guedes, G. Smagghe, J. Stark, N. Desneux, Pesticide-induced stress in arthropod pests for optimized integrated pest management programs, Annual review of entomology, 61 (2016) 43-62.

[42] W. Zhang, F. Jiang, J. Ou, Global pesticide consumption and pollution: with China as a focus, Proceedings of the International Academy of Ecology and Environmental Sciences, 1 (2011) 125.

[43] I.C. Yadav, N.L. Devi, J.H. Syed, Z. Cheng, J. Li, G. Zhang, K.C. Jones, Current status of persistent organic pesticides residues in air, water, and soil, and their possible effect on neighboring countries: a comprehensive review of India, Science of the Total Environment, 511 (2015) 123-137.

[44] A.E. Hajek, J. Eilenberg, Natural enemies: an introduction to biological control, Cambridge University Press, 2018.

[45] D.K. Gupta, S. Tiwari, B. Razafindrabe, S. Chatterjee, Arsenic contamination from historical aspects to the present, in: Arsenic Contamination in the Environment, Springer, 2017, pp. 1-12.

[46] S. Savci, An agricultural pollutant: chemical fertilizer, International Journal of Environmental Science and Development, 3 (2012) 73.

[47] S. Sahu, P. Ajmal, R. Bhangare, M. Tiwari, G. Pandit, Natural radioactivity assessment of a phosphate fertilizer plant area, Journal of Radiation Research and Applied Sciences, 7 (2014) 123-128.

[48] B.J. Alloway, Heavy metals and metalloids as micronutrients for plants and animals, in: Heavy metals in soils, Springer, 2013, pp. 195-209. 
[49] D. Gupta, S. Chatterjee, S. Datta, V. Veer, C. Walther, Role of phosphate fertilizers in heavy metal uptake and detoxification of toxic metals, Chemosphere, 108 (2014) 134-144.

[50] S. Sattari, M. Van Ittersum, K. Giller, F. Zhang, A. Bouwman, Key role of China and its agriculture in global sustainable phosphorus management, Environmental Research Letters, 9 (2014) 054003.

[51] J.N. Ihedioha, O.T. Ujam, C.O. Nwuche, N.R. Ekere, C.C. Chime, Assessment of heavy metal contamination of rice grains (Oryza sativa) and soil from Ada field, Enugu, Nigeria: Estimating the human healtrisk, Human and Ecological Risk Assessment: An International Journal, 22 (2016) 1665-1677.

[52] P. Ravenscroft, H. Brammer, K. Richards, Arsenic pollution: a global synthesis, John Wiley \& Sons, 2009.

[53] L. Luo, Y. Ma, S. Zhang, D. Wei, Y.-G. Zhu, An inventory of trace element inputs to agricultural soils in China, Journal of Environmental Management, 90 (2009) 2524-2530.

[54] G. Nziguheba, E. Smolders, Inputs of trace elements in agricultural soils via phosphate fertilizers in European countries, Science of the Total Environment, 390 (2008) 53-57.

[55] M. Shahid, T. Xiong, N. Masood, T. Leveque, K. Quenea, A. Austruy, Y. Foucault, C. Dumat, Influence of plant species and phosphorus amendments on metal speciation and bioavailability in a smelter impacted soil: a case study of foodchain contamination, Journal of soils and sediments, 14 (2014) 655-665.

[56] B. Wang, Z. Xie, J. Chen, J. Jiang, Q. Su, Effects of field application of phosphate fertilizers on the availability and uptake of lead, zinc and cadmium by cabbage (Brassica chinensis L.) in a mining tailing contaminated soil, Journal of Environmental Sciences, 20 (2008) 1109-1117.

[57] S.E. Wortman, S.T. Lovell, Environmental challenges threatening the growth of urban agriculture in the United States, Journal of environmental quality, 42 (2013) 1283-1294. 
[58] D. Satpathy, M.V. Reddy, S.P. Dhal, Risk assessment of heavy metals contamination in paddy soil, plants, and grains (Oryza sativa L.) at the East Coast of India, BioMed research international, 2014 (2014).

[59] M. Hezbullah, S. Sultana, S. Chakraborty, M. Patwary, Heavy metal contamination of food in a developing country like Bangladesh: An emerging threat to food safety, Journal of Toxicology and Environmental Health Sciences, 8 (2016) 1-5.

[60] Z. Wang, J. Li, Y. Li, Using reclaimed water for agricultural and landscape irrigation in China: a review, Irrigation and drainage, 66 (2017) 672-686.

[61] B. Jiménez, P. Drechsel, D. Koné, A. Bahri, Wastewater, sludge and excreta use in developing countries: an overview, in: Wastewater irrigation and health, Routledge, 2009, pp. 29-54.

[62] R. Clarke, Water: the international crisis, Routledge, 2013.

[63] G.S. Pettygrove, Irrigation with reclaimed municipal wastewater-A guidance manual, CRC Press, 2018.

[64] M. Elgallal, L. Fletcher, B. Evans, Assessment of potential risks associated with chemicals in wastewater used for irrigation in arid and semiarid zones: A review, Agricultural Water Management, 177 (2016) 419-431.

[65] J. Mateo-Sagasta, L. Raschid-Sally, A. Thebo, Global wastewater and sludge production, treatment and use, in: Wastewater, Springer, 2015, pp. 15-38.

[66] S. Biswas, M. Mojid, G. Wyseure, Physicochemical properties of soil under wheat cultivation by irrigation with municipal wastewater in Bangladesh, Communications in soil science and plant analysis, 48 (2017) 1-10.

[67] G. Murtaza, A. Ghafoor, M. Qadir, G. Owens, M. Aziz, M. Zia, Disposal and use of sewage on agricultural lands in Pakistan: A review, Pedosphere, 20 (2010) 23-34.

[68] A. Baysal, N. Ozbek, S. Akman, Determination of trace metals in waste water and their removal processes, Waste-Water Treatment Technologies and Recent Analytical Developments (ed. FSG Einschlag, L. Carlos), (2013) 145-171.

[69] P. Rajasulochana, V. Preethy, Comparison on efficiency of various techniques in treatment of waste and sewage water-A comprehensive review, ResourceEfficient Technologies, 2 (2016) 175-184. 
[70] M. Qadir, D. Wichelns, L. Raschid-Sally, P.G. McCornick, P. Drechsel, A. Bahri, P. Minhas, The challenges of wastewater irrigation in developing countries, Agricultural Water Management, 97 (2010) 561-568.

[71] Z. Chen, Y. Zhao, Q. Li, J. Qiao, Q. Tian, X. Liu, Heavy metal contents and chemical speciations in sewage-irrigated soils from the eastern suburb of Beijing, China, Journal of food, agriculture \& environment, (2009).

[72] Y. Zhang, H.-W. Zhang, S. Zhen-Cheng, C.-G. Zhang, Soil microbial characteristics under long-term heavy metal stress: a case study in Zhangshi wastewater irrigation area, Shenyang, Pedosphere, 18 (2008) 1-10.

[73] C. Pathak, A. Chopra, V. Kumar, S. Srivastava, Heavy metals contamination in waste-water irrigated agricultural soil near Bindal river, Dehradun, India, Poll Res, 29 (2010) 583â.

[74] A. Mishra, B.D. Tripathi, Heavy metal contamination of soil, and bioaccumulation in vegetables irrigated with treated waste water in the tropical city of Varanasi, India, Toxicological and Environmental Chemistry, 90 (2008) 861-871.

[75] N.U. Hassan, Q. Mahmood, A. Waseem, M. Irshad, A. Pervez, Assessment of Heavy Metals in Wheat Plants Irrigated with Contaminated Wastewater, Polish Journal of Environmental Studies, 22 (2013).

[76] N.T.L. Huong, M. Ohtsubo, L. LI, T. Higashi, M. Kanayama, A. Nakano, Heavy metal contamination of soil and rice in wastewater-irrigated paddy field in a suburban area of Hanoi, Vietnam, Clay science, 13 (2008) 205-215.

[77] O. Cimen, G. Gok, H. Celebi, O. Gok, The possible environmental impacts of the biosolids in the worldwide, Journal of Selcuk University Natural and Applied Science, 4 (2014) 1144-1154.

[78] K. Yin, A. Ahamed, G. Lisak, Environmental perspectives of recycling various combustion ashes in cement production-A review, Waste management, 78 (2018) 401-416.

[79] H. Chen, S. Yan, Z. Ye, H. Meng, Y. Zhu, Utilization of urban sewage sludge: Chinese perspectives, Environmental Science and Pollution Research, 19 (2012) 1454-1463. 
[80] G. Yang, G. Zhang, H. Wang, Current state of sludge production, management, treatment and disposal in China, Water research, 78 (2015) 60-73.

[81] R. Singh, N. Gautam, A. Mishra, R. Gupta, Heavy metals and living systems: An overview, Indian journal of pharmacology, 43 (2011) 246.

[82] T. Głąb, A. Żabiński, U. Sadowska, K. Gondek, M. Kopeć, M. Mierzwa-Hersztek, S. Tabor, Effects of co-composted maize, sewage sludge, and biochar mixtures on hydrological and physical qualities of sandy soil, Geoderma, 315 (2018) 27 35 .

[83] J.O. Babayemi, M.B. Ogundiran, O. Osibanjo, Overview of environmental hazards and health effects of pollution in developing countries: a case study of Nigeria, Environmental Quality Management, 26 (2016) 51-71.

[84] R. Singh, M. Agrawal, Variations in heavy metal accumulation, growth and yield of rice plants grown at different sewage sludge amendment rates, Ecotoxicology and environmental safety, 73 (2010) 632-641.

[85] X. Guoqing, C. Xiuqin, B. Liping, Q. Hongtao, L. Haibo, Absorption, accumulation and distribution of metals and nutrient elements in poplars planted in land amended with composted sewage sludge: A field trial, Ecotoxicology and environmental safety, 182 (2019) 109360.

[86] A.T. Nair, M.M. Ahammed, The reuse of water treatment sludge as a coagulant for post-treatment of UASB reactor treating urban wastewater, Journal of Cleaner Production, 96 (2015) 272-281.

[87] M.d.M.D. Arroyo, R.M.D.I. Hornedo, F.A. Peralta, C.R. Almestre, J.V.M. Sánchez, Heavy metals concentration in soil, plant, earthworm and leachate from poultry manure applied to agricultural land, Revista internacional de contaminación ambiental, 30 (2014) 43-50.

[88] Y. Hu, H. Cheng, S. Tao, Environmental and human health challenges of industrial livestock and poultry farming in China and their mitigation, Environment international, 107 (2017) 111-130.

[89] W. Zhang, R. Sheng, M. Zhang, G. Xiong, H. Hou, S. Li, W. Wei, Effects of continuous manure application on methanogenic and methanotrophic 
communities and methane production potentials in rice paddy soil, Agriculture, ecosystems \& environment, 258 (2018) 121-128.

[90] M.E. Zain, Impact of mycotoxins on humans and animals, Journal of Saudi Chemical Society, 15 (2011) 129-144.

[91] P. Ziarati, F. Shirkhan, M. Mostafidi, M. Zahedi, An overview of the heavy metal contamination in milk and dairy products, Acta Sci. Pharm. Sci, 2 (2018) 8-21.

[92] Y. Zhao, Z. Yan, J. Qin, Z. Xiao, Effects of long-term cattle manure application on soil properties and soil heavy metals in corn seed production in Northwest China, Environmental Science and Pollution Research, 21 (2014) 7586-7595.

[93] B. Zhengfu, H.I. Inyang, J.L. Daniels, O. Frank, S. Struthers, Environmental issues from coal mining and their solutions, Mining Science and Technology (China), 20 (2010) 215-223.

[94] A.K. Krishna, K.R. Mohan, N. Murthy, V. Periasamy, G. Bipinkumar, K. Manohar, S.S. Rao, Assessment of heavy metal contamination in soils around chromite mining areas, Nuggihalli, Karnataka, India, Environmental earth sciences, 70 (2013) 699-708.

[95] X. Wang, X. Zeng, L. Chuanping, F. Li, X. Xu, Y. Lv, Heavy metal contaminations in soil-rice system: source identification in relation to a sulfur-rich coal burning power plant in Northern Guangdong Province, China, Environmental monitoring and assessment, 188 (2016) 460.

[96] B. González-Corrochano, J. Esbrí, J. Alonso-Azcárate, A. Martínez-Coronado, V. Jurado, P. Higueras, Environmental geochemistry of a highly polluted area: the $\mathrm{La}$ Union $\mathrm{Pb}-\mathrm{Zn}$ mine (Castilla-La Mancha region, Spain), Journal of Geochemical Exploration, 144 (2014) 345-354.

[97] C. Candeias, R. Melo, P.F. Ávila, E.F. da Silva, A.R. Salgueiro, J.P. Teixeira, Heavy metal pollution in mine-soil-plant system in S. Francisco de Assis-Panasqueira mine (Portugal), Applied Geochemistry, 44 (2014) 12-26.

[98] C. Qin, C. Luo, Y. Chen, Z. Shen, Spatial-based assessment of metal contamination in agricultural soils near an abandoned copper mine of Eastern China, Bulletin of environmental contamination and toxicology, 89 (2012) 113-118. 
[99] N. Rogan, T. Serafimovski, M. Dolenec, G. Tasev, T. Dolenec, Heavy metal contamination of paddy soils and rice (Oryza sativa L.) from Kočani Field (Macedonia), Environmental Geochemistry and Health, 31 (2009) 439-451.

[100] C.N. Kien, N.V. Noi, L.T. Son, H.M. Ngoc, S. Tanaka, T. Nishina, K. Iwasaki, Heavy metal contamination of agricultural soils around a chromite mine in Vietnam, Soil Science \& Plant Nutrition, 56 (2010) 344-356.

[101] T.T.H. Chu, Survey on heavy metals contaminated soils in Thai Nguyen and Hung Yen provinces in Northern Vietnam, (2011).

[102] J. Bai, B. Cui, Q. Wang, H. Gao, Q. Ding, Assessment of heavy metal contamination of roadside soils in Southwest China, Stochastic environmental research and risk assessment, 23 (2009) 341-347.

[103] V. Funari, S.N.H. Bokhari, L. Vigliotti, T. Meisel, R. Braga, The rare earth elements in municipal solid waste incinerators ash and promising tools for their prospecting, Journal of Hazardous Materials, 301 (2016) 471-479.

[104] F. Mushtaq, R. Mat, F.N. Ani, A review on microwave assisted pyrolysis of coal and biomass for fuel production, Renewable and Sustainable Energy Reviews, 39 (2014) 555-574.

[105] K.Y. Awan, A. Rashid, Overview of Pakistan's electricity crisis, generation-mix and renewable energy scenarios, International Journal of Engineering \& Technology, 1 (2012) 321-334.

[106] S.K. Guttikunda, P. Jawahar, Atmospheric emissions and pollution from the coalfired thermal power plants in India, Atmospheric environment, 92 (2014) 449460.

[107] X.-Q. Tao, D.-S. Shen, J.-L. Shentu, Y.-Y. Long, Y.-J. Feng, C.-C. Shen, Bioaccessibility and health risk of heavy metals in ash from the incineration of different e-waste residues, Environmental Science and Pollution Research, 22 (2015) 3558-3569.

[108] A. Nayak, R. Raja, K. Rao, A. Shukla, S. Mohanty, M. Shahid, R. Tripathi, B. Panda, P. Bhattacharyya, A. Kumar, Effect of fly ash application on soil microbial response and heavy metal accumulation in soil and rice plant, Ecotoxicology and environmental safety, 114 (2015) 257-262. 
[109] F.C. Bretzel, M. Calderisi, Contribution of a municipal solid waste incinerator to the trace metals in the surrounding soil, Environmental monitoring and assessment, 182 (2011) 523-533.

[110] V. Parth, N. Murthy, P.R. Saxena, Assessment of heavy metal contamination in soil around hazardous waste disposal sites in Hyderabad city (India): natural and anthropogenic implications, Journal of Environmental research and management, 2 (2011) 027-034.

[111] N. Bolan, A. Kunhikrishnan, R. Thangarajan, J. Kumpiene, J. Park, T. Makino, M.B. Kirkham, K. Scheckel, Remediation of heavy metal (loid) s contaminated soils-to mobilize or to immobilize?, Journal of Hazardous Materials, 266 (2014) 141-166.

[112] J. Jadoun, M. Singh, A Study of Physico-Chemical Properties \& Heavy Metals in Contaminated Soils of Municipal Waste Dumpsite at Dholpur, International Journal of Sciences, 3 (2014).

[113] A. Tripathi, D. Misra, A study of physico-chemical properties and heavy metals in contaminated soils of municipal waste dumpsites at Allahabad, India, International journal of environmental sciences, 2 (2012) 2024.

[114] A. Borthakur, M. Govind, Emerging trends in consumers' E-waste disposal behaviour and awareness: A worldwide overview with special focus on India, Resources, Conservation and Recycling, 117 (2017) 102-113.

[115] W.-H. ZHANG, W. Ying-Xin, M. Simonnot, Soil contamination due to e-waste disposal and recycling activities: a review with special focus on China, Pedosphere, 22 (2012) 434-455.

[116] N.M. Tue, A. Goto, S. Takahashi, T. Itai, K.A. Asante, T. Kunisue, S. Tanabe, Release of chlorinated, brominated and mixed halogenated dioxin-related compounds to soils from open burning of e-waste in Agbogbloshie (Accra, Ghana), Journal of Hazardous Materials, 302 (2016) 151-157.

[117] J. Fu, Q. Zhou, J. Liu, W. Liu, T. Wang, Q. Zhang, G. Jiang, High levels of heavy metals in rice (Oryzasativa L.) from a typical E-waste recycling area in southeast China and its potential risk to human health, Chemosphere, 71 (2008) 1269-1275. 
[118] N. Majed, M. Real, H. Isreq, M. Akter, H.M. Azam, Food adulteration and biomagnification of environmental contaminants: a comprehensive risk framework for Bangladesh, Frontiers in Environmental Science, 4 (2016) 34.

[119] M.S. Islam, M.K. Ahmed, M. Habibullah-Al-Mamun, Metal speciation in soil and health risk due to vegetables consumption in Bangladesh, Environmental monitoring and assessment, 187 (2015) 288.

[120] B. Huang, Z. Li, J. Huang, G. Chen, X. Nie, W. Ma, H. Yao, J. Zhen, G. Zeng, Aging effect on the leaching behavior of heavy metals $(\mathrm{Cu}, \mathrm{Zn}$, and $\mathrm{Cd})$ in red paddy soil, Environmental Science and Pollution Research, 22 (2015) 1146711477.

[121] T. Rudra, S.M. Basher, The Prevalence of Heavy Metals (Arsenic) in Soils around Kuala Lumpur City, Malaysia.

[122] P. Bhattacharya, A.B. Mukherjee, J. Bundschuh, R. Zevenhoven, R.H. Loeppert, Arsenic in soil and groundwater environment: biogeochemical interactions, health effects and remediation, Elsevier, 2007.

[123] H.-J. Sun, B. Rathinasabapathi, B. Wu, J. Luo, L.-P. Pu, L.Q. Ma, Arsenic and selenium toxicity and their interactive effects in humans, Environment international, 69 (2014) 148-158.

[124] J. Zhang, Fate and Transport of Arsenic in Construction and Demolition Debris Landfills and Soils Underneath, University of Florida, 2011.

[125] M. Chiban, M. Zerbet, G. Carja, F. Sinan, Application of low-cost adsorbents for arsenic removal: A review, Journal of Environmental Chemistry and Ecotoxicology, 4 (2012) 91-102.

[126] K.M. Campbell, D.K. Nordstrom, Arsenic speciation and sorption in natural environments, Reviews in Mineralogy and Geochemistry, 79 (2014) 185-216.

[127] S.C. Wilson, P.V. Lockwood, P.M. Ashley, M. Tighe, The chemistry and behaviour of antimony in the soil environment with comparisons to arsenic: a critical review, Environmental pollution, 158 (2010) 1169-1181.

[128] M. Roy, A.K. Giri, S. Dutta, P. Mukherjee, Integrated phytobial remediation for sustainable management of arsenic in soil and water, Environment international, 75 (2015) 180-198. 
[129] P. Wang, G. Sun, Y. Jia, A.A. Meharg, Y. Zhu, A review on completing arsenic biogeochemical cycle: microbial volatilization of arsines in environment, Journal of Environmental Sciences, 26 (2014) 371-381.

[130] F. Wu, Z. Fu, B. Liu, C. Mo, B. Chen, W. Corns, H. Liao, Health risk associated with dietary co-exposure to high levels of antimony and arsenic in the world's largest antimony mine area, Science of the Total Environment, 409 (2011) 33443351.

[131] M.A. Rahman, H. Hasegawa, R.P. Lim, Bioaccumulation, biotransformation and trophic transfer of arsenic in the aquatic food chain, Environmental research, 116 (2012) 118-135.

[132] R. Singh, S. Singh, P. Parihar, V.P. Singh, S.M. Prasad, Arsenic contamination, consequences and remediation techniques: a review, Ecotoxicology and environmental safety, 112 (2015) 247-270.

[133] J. Gailer, Arsenic-selenium and mercury-selenium bonds in biology, Coordination Chemistry Reviews, 251 (2007) 234-254.

[134] M.F. Hughes, B.D. Beck, Y. Chen, A.S. Lewis, D.J. Thomas, Arsenic exposure and toxicology: a historical perspective, Toxicological Sciences, 123 (2011) 305-332.

[135] K.G. Brown, G.L. Ross, Arsenic, drinking water, and health: a position paper of the American Council on Science and Health, Regulatory Toxicology and Pharmacology, 36 (2002) 162-174.

[136] V. Chandrakar, N. Pandey, S. Keshavkant, Plant Responses to Arsenic Toxicity: Morphology and Physiology, in: Mechanisms of Arsenic Toxicity and Tolerance in Plants, Springer, 2018, pp. 27-48.

[137] W. Ali, N. Mushtaq, T. Javed, H. Zhang, K. Ali, A. Rasool, A. Farooqi, Vertical mixing with return irrigation water the cause of arsenic enrichment in groundwater of district Larkana Sindh, Pakistan, Environmental pollution, 245 (2019) 77-88.

[138] U. Tinggi, Essentiality and toxicity of selenium and its status in Australia: a review, Toxicology letters, 137 (2003) 103-110.

[139] P. Hooda, Trace elements in soils, John Wiley \& Sons, 2010. 
[140] I. Zwolak, H. Zaporowska, Selenium interactions and toxicity: a review, Cell biology and toxicology, 28 (2012) 31-46.

[141] H. Zeng, E.O. Uthus, G.F. Combs, Mechanistic aspects of the interaction between selenium and arsenic, Journal of inorganic biochemistry, 99 (2005) 1269-1274.

[142] I. Zwolak, The Role of Selenium in Arsenic and Cadmium Toxicity: an Updated Review of Scientific Literature, Biological trace element research, (2019) 1-20.

[143] W. Ali, H. Zhang, M. Junaid, K. Mao, N. Xu, C. Chang, A. Rasool, M. Wajahat Aslam, J. Ali, Z. Yang, Insights into the mechanisms of arsenic-selenium interactions and the associated toxicity in plants, animals, and humans: A critical review, Critical Reviews in Environmental Science and Technology, (2020) 1-47.

[144] J. Lu, C. Jiang, Antiangiogenic activity of selenium in cancer chemoprevention: metabolite-specific effects, Nutrition and cancer, 40 (2001) 64-73.

[145] H. Zeng, Selenium as an essential micronutrient: roles in cell cycle and apoptosis, Molecules, 14 (2009) 1263-1278.

[146] G.D. Jones, B. Droz, P. Greve, P. Gottschalk, D. Poffet, S.P. McGrath, S.I. Seneviratne, P. Smith, L.H. Winkel, Selenium deficiency risk predicted to increase under future climate change, Proceedings of the National Academy of Sciences, 114 (2017) 2848-2853.

[147] M. Shahid, N.K. Niazi, S. Khalid, B. Murtaza, I. Bibi, M.I. Rashid, A critical review of selenium biogeochemical behavior in soil-plant system with an inference to human health, Environmental pollution, 234 (2018) 915-934.

[148] M. Navarro-Alarcon, C. Cabrera-Vique, Selenium in food and the human body: a review, Science of the Total Environment, 400 (2008) 115-141.

[149] L.H. Winkel, C.A. Johnson, M. Lenz, T. Grundl, O.X. Leupin, M. Amini, L. Charlet, Environmental selenium research: from microscopic processes to global understanding, in, ACS Publications, 2011.

[150] M. Gupta, S. Gupta, An overview of selenium uptake, metabolism, and toxicity in plants, Frontiers in Plant Science, 7 (2017) 2074.

[151] C. Chang, R. Yin, X. Wang, S. Shao, C. Chen, H. Zhang, Selenium translocation in the soil-rice system in the Enshi seleniferous area, Central China, Science of the Total Environment, 669 (2019) 83-90. 
[152] M. Vinceti, T. Maraldi, M. Bergomi, C. Malagoli, Risk of chronic low-dose selenium overexposure in humans: insights from epidemiology and biochemistry, Reviews on environmental health, 24 (2009) 231-248.

[153] F.M. Fordyce, Selenium deficiency and toxicity in the environment, in: Essentials of medical geology, Springer, 2013, pp. 375-416.

[154] R. Chauhan, S. Awasthi, S. Srivastava, S. Dwivedi, E.A. Pilon-Smits, O.P. Dhankher, R.D. Tripathi, Understanding selenium metabolism in plants and its role as a beneficial element, Critical Reviews in Environmental Science and Technology, (2019) 1-22.

[155] M. Soliman, S. Potlakayala, D. Millar, H. Weeden, D. Bogush, M. Deguchi, S. Rudrabhatla, Comparing A Review of Heavy Metal Uptake and Their Toxicity on Plant and Human Health, Int J Plant Anim Environ Sci, 9 (2019) 182-189.

[156] Y. Nzengue, S.M. Candéias, S. Sauvaigo, T. Douki, A. Favier, W. Rachidi, P. Guiraud, The toxicity redox mechanisms of cadmium alone or together with copper and zinc homeostasis alteration: its redox biomarkers, Journal of Trace elements in Medicine and Biology, 25 (2011) 171-180.

[157] J. Musa, H. Mustapha, J. Bala, Y. Ibrahim, M. Akos, E. Daniel, F. Oguche, I. Kuti, Heavy metals in agricultural soils in Nigeria: A review, Arid Zone Journal of Engineering, Technology and Environment, 13 (2017) 593-603.

[158] J. Shi, X. Yu, M. Zhang, S. Lu, W. Wu, J. Wu, J. Xu, Potential risks of copper, zinc, and cadmium pollution due to pig manure application in a soil-rice system under intensive farming: a case study of Nanhu, China, Journal of environmental quality, 40 (2011) 1695-1704.

[159] C.-B. Leng, W. Wang, L. Ye, X.-C. Zhang, Genesis of the late Ordovician Kukaazi $\mathrm{Pb}-\mathrm{Zn}$ deposit in the western Kunlun orogen, NW China: New insights from insitu trace elemental compositions of base metal sulfides, Journal of Asian Earth Sciences, 184 (2019) 103995.

[160] Y. Pan, Speciation of trace metals and their uptake by rice in paddy soils, Wageningen University, 2015.

[161] P. Hu, Z. Li, C. Yuan, Y. Ouyang, L. Zhou, J. Huang, Y. Huang, Y. Luo, P. Christie, L. Wu, Effect of water management on cadmium and arsenic accumulation by 
rice (Oryza sativa L.) with different metal accumulation capacities, Journal of soils and sediments, 13 (2013) 916-924.

[162] V. Matović, A. Buha, D. Đukić-Ćosić, Z. Bulat, Insight into the oxidative stress induced by lead and/or cadmium in blood, liver and kidneys, Food and Chemical Toxicology, 78 (2015) 130-140.

[163] E. Scerri, The periodic table: its story and its significance, Oxford University Press, 2019.

[164] S. Chen, L. Sun, L. Chao, Q. Zhou, T. Sun, Estimation of lead bioavailability in smelter-contaminated soils by single and sequential extraction procedure, Bulletin of environmental contamination and toxicology, 82 (2009) 43-47.

[165] G. Huang, X. Su, M.S. Rizwan, Y. Zhu, H. Hu, Chemical immobilization of Pb, $\mathrm{Cu}$, and $\mathrm{Cd}$ by phosphate materials and calcium carbonate in contaminated soils, Environmental Science and Pollution Research, 23 (2016) 16845-16856.

[166] R.L. Hough, Copper and lead, Trace elements in soils, (2010) 441.

[167] A. Potysz, M. Grybos, J. Kierczak, G. Guibaud, P. Fondaneche, P.N. Lens, E.D. van Hullebusch, Metal mobilization from metallurgical wastes by soil organic acids, Chemosphere, 178 (2017) 197-211.

[168] E. Farkas, P. Buglyó, Lead (II) Complexes of Amino Acids, Peptides, and Other Related Ligands of Biological Interest, Lead: Its Effects on Environment and Health, 17 (2017) 201.

[169] A. Violante, Elucidating mechanisms of competitive sorption at the mineral/water interface, in: Advances in agronomy, Elsevier, 2013, pp. 111-176.

[170] K.-s. Liu, J.-h. Hao, Y. Zeng, F.-c. Dai, P.-q. Gu, Neurotoxicity and biomarkers of lead exposure: a review, Chinese Medical Sciences Journal, 28 (2013) 178-188.

[171] L. Patrick, Lead Toxicity, a review of the literature. Part I: Exposure, Evaluation, and treatment, Alternative medicine review, 11 (2006).

[172] J. Kumpiene, A. Lagerkvist, C. Maurice, Stabilization of $\mathrm{As}, \mathrm{Cr}, \mathrm{Cu}, \mathrm{Pb}$ and $\mathrm{Zn}$ in soil using amendments-a review, Waste management, 28 (2008) 215-225.

[173] E.B.Ö. Güngör, M. Bekbölet, Zinc release by humic and fulvic acid as influenced by $\mathrm{pH}$, complexation and DOC sorption, Geoderma, 159 (2010) 131-138. 
[174] R. Prasad, Y.S. Shivay, D. Kumar, Interactions of zinc with other nutrients in soils and plants-a Review, Indian Journal of Fertilisers, 12 (2016) 16-26.

[175] M. Zalewska, Response of perennial ryegrass (Lolium perenne L.) to soil contamination with zinc, Journal of Elementology, 17 (2012).

[176] P. Loganathan, S. Vigneswaran, J. Kandasamy, R. Naidu, Cadmium sorption and desorption in soils: a review, Critical Reviews in Environmental Science and Technology, 42 (2012) 489-533.

[177] R. Prasanna, Bioprospecting of Neem and Hibiscus against Corrosion Caused By Soil Microbes on Zinc and Its Alloys Buried In Soil, (2017).

[178] J.D. Deshpande, M.M. Joshi, P.A. Giri, Zinc: The trace element of major importance in human nutrition and health, Int J Med Sci Public Health, 2 (2013) $1-6$.

[179] Z.L. He, J. Shentu, X.E. Yang, Manganese and selenium, Trace elements in soils. London: Wiley, (2010) 481-496.

[180] S.M. Shaheen, C.D. Tsadilas, J. Rinklebe, A review of the distribution coefficients of trace elements in soils: Influence of sorption system, element characteristics, and soil colloidal properties, Advances in Colloid and Interface Science, 201 (2013) 43-56.

[181] B. Sarbas, Mn Manganese: Natural Occurrence. Minerals (Native metal, solid solution, silicide, and carbide. Sulfides and related compounds. Halogenides and oxyhalogenides. Oxides of type MO), Springer Science \& Business Media, 2013.

[182] H. Tan, G. Zhang, P.J. Heaney, S.M. Webb, W.D. Burgos, Characterization of manganese oxide precipitates from Appalachian coal mine drainage treatment systems, Applied Geochemistry, 25 (2010) 389-399.

[183] Y.N. Vodyanitskii, Mineralogy and geochemistry of manganese: a review of publications, Eurasian Soil Science, 42 (2009) 1170-1178.

[184] Z. Rengel, Manganese Uptake and Transport, Metal Ions in Biological Systems: Volume 37: Manganese and Its Role in Biological Processes, (2000) 57.

[185] V. Antoniadis, E.E. Golia, Y.-T. Liu, S.-L. Wang, S.M. Shaheen, J. Rinklebe, Soil and maize contamination by trace elements and associated health risk assessment 
in the industrial area of Volos, Greece, Environment international, 124 (2019) 7988.

[186] Y.-y. Zhang, J.-w. Lv, X.-j. Dong, Q. Fang, W.-f. Tan, X.-y. Wu, Q.-w. Deng, Influence on Uranium (VI) migration in soil by iron and manganese salts of humic acid: Mechanism and behavior, Environmental pollution, (2019) 113369.

[187] C.M. McCann, The use of natural Mn oxide-containing wastes as a contaminated land remediation strategy and their effects on soil microbial functioning, in, Newcastle University, 2012.

[188] K. Soetan, C. Olaiya, O. Oyewole, The importance of mineral elements for humans, domestic animals and plants-A review, African journal of food science, 4 (2010) 200-222.

[189] J.A. Menezes-Filho, C.R. Paes, Â.M.d.C. Pontes, J.C. Moreira, P.N. Sarcinelli, D. Mergler, High levels of hair manganese in children living in the vicinity of a ferromanganese alloy production plant, Neurotoxicology, 30 (2009) 1207-1213.

[190] V. Pahade, A. Sharma, Manganese removal by low cost adsorbent from synthetic wastewater-A review, Int J Eng Res, 4 (2015) 111-114.

[191] M. Ferrante, Manganese (Mn), Health Effects of Metals and Related Substances in Drinking Water, (2013) 71.

[192] Y. Ma, P.S. Hooda, Chromium, nickel and cobalt, Trace elements in soils, (2010) 461-480.

[193] J. Musa, H. Mustapha, J. Bala, Y. Ibrahim, M. Akos, E. Daniel, F. Oguche, I. Kuti, Heavy metals in agricultural soils in Nigeria: A review, Arid Zone Journal of Engineering, Technology and Environment, 13 (2017) 593.

[194] V. Antoniadis, E. Levizou, S.M. Shaheen, Y.S. Ok, A. Sebastian, C. Baum, M.N. Prasad, W.W. Wenzel, J. Rinklebe, Trace elements in the soil-plant interface: Phytoavailability, translocation, and phytoremediation-A review, Earth-Science Reviews, 171 (2017) 621-645.

[195] G. Echevarria, Genesis and behaviour of ultramafic soils and consequences for nickel biogeochemistry, in: Agromining: Farming for Metals, Springer, 2018, pp. $135-156$. 
[196] M. Vithanage, A.U. Rajapaksha, C. Oze, N. Rajakaruna, C. Dissanayake, Metal release from serpentine soils in Sri Lanka, Environmental monitoring and assessment, 186 (2014) 3415-3429.

[197] A. Violante, V. Cozzolino, L. Perelomov, A. Caporale, M. Pigna, Mobility and bioavailability of heavy metals and metalloids in soil environments, Journal of soil science and plant nutrition, 10 (2010) 268-292.

[198] S. Yang, G. Sheng, X. Tan, J. Hu, J. Du, G. Montavon, X. Wang, Determination of $\mathrm{Ni}$ (II) uptake mechanisms on mordenite surfaces: a combined macroscopic and microscopic approach, Geochimica et Cosmochimica Acta, 75 (2011) 6520-6534.

[199] J. Rinklebe, S.M. Shaheen, Redox chemistry of nickel in soils and sediments: a review, Chemosphere, 179 (2017) 265-278.

[200] E. Igberase, P. Osifo, A. Ofomaja, Mathematical modelling of $\mathrm{Pb} 2+, \mathrm{Cu} 2+, \mathrm{Ni} 2+$, $\mathrm{Zn} 2+, \mathrm{Cr} 6+$ and $\mathrm{Cd} 2+$ ions adsorption from a synthetic acid mine drainage onto chitosan derivative in a packed bed column, Environmental technology, 39 (2018) 3203-3220.

[201] S.H. Abbas, I.M. Ismail, T.M. Mostafa, A.H. Sulaymon, Biosorption of heavy metals: a review, Journal of Chemical Science and Technology, 3 (2014) 74-102.

[202] K.O. Konhauser, E. Pecoits, S.V. Lalonde, D. Papineau, E.G. Nisbet, M.E. Barley, N.T. Arndt, K. Zahnle, B.S. Kamber, Oceanic nickel depletion and a methanogen famine before the Great Oxidation Event, Nature, 458 (2009) 750.

[203] G. Du Laing, J. Rinklebe, B. Vandecasteele, E. Meers, F.M. Tack, Trace metal behaviour in estuarine and riverine floodplain soils and sediments: a review, Science of the Total Environment, 407 (2009) 3972-3985.

[204] M. Ehsan, M. Barakat, D.Z. Husein, S. Ismail, Immobilization of Ni and Cd in soil by biochar derived from unfertilized dates, Water, Air, \& Soil Pollution, 225 (2014) 2123.

[205] D.C. Adriano, Trace elements in the terrestrial environment, Springer Science \& Business Media, 2013.

[206] M. Jaishankar, T. Tseten, N. Anbalagan, B.B. Mathew, K.N. Beeregowda, Toxicity, mechanism and health effects of some heavy metals, Interdisciplinary toxicology, 7 (2014) 60-72. 
[207] K. Salnikow, A. Zhitkovich, Genetic and epigenetic mechanisms in metal carcinogenesis and cocarcinogenesis: nickel, arsenic, and chromium, Chemical research in toxicology, 21 (2007) 28-44.

[208] R. Saha, R. Nandi, B. Saha, Sources and toxicity of hexavalent chromium, Journal of Coordination Chemistry, 64 (2011) 1782-1806.

[209] J. Guertin, C.P. Avakian, J.A. Jacobs, Chromium (VI) handbook, CRC press, 2016.

[210] M. Dotaniya, J. Thakur, V. Meena, D. Jajoria, G. Rathor, Chromium pollution: a threat to environment-a review, Agricultural Reviews, 35 (2014).

[211] B. Jiang, Y. Gong, J. Gao, T. Sun, Y. Liu, N. Oturan, M.A. Oturan, Reductive detoxification of $\mathrm{Cr}(\mathrm{VI})$ mediated by environmentally relevant carboxylic acids: State-of-the-art and perspectives, Journal of Hazardous Materials, (2018).

[212] D.K. Nordstrom, Hydrogeochemical processes governing the origin, transport and fate of major and trace elements from mine wastes and mineralized rock to surface waters, Applied Geochemistry, 26 (2011) 1777-1791.

[213] A. Teklay, Physiological effect of chromium exposure: A review, Int. J. Food Sci. Nutr. Diet. S, 7 (2016) 1-11.

[214] R. Khanam, A. Kumar, A. Nayak, M. Shahid, R. Tripathi, S. Vijayakumar, D. Bhaduri, U. Kumar, S. Mohanty, P. Panneerselvam, Metal (loid) s (As, Hg, Se, $\mathrm{Pb}$ and $\mathrm{Cd}$ ) in paddy soil: Bioavailability and potential risk to human health, Science of the Total Environment, (2019) 134330.

[215] J.C. Kwon, Z.D. Nejad, M.C. Jung, Arsenic and heavy metals in paddy soil and polished rice contaminated by mining activities in Korea, Catena, 148 (2017) 92100.

[216] M. Dotaniya, V. Meena, Rhizosphere effect on nutrient availability in soil and its uptake by plants: a review, Proceedings of the National Academy of Sciences, India Section B: Biological Sciences, 85 (2015) 1-12.

[217] S.-Y. Zhang, F.-J. Zhao, G.-X. Sun, J.-Q. Su, X.-R. Yang, H. Li, Y.-G. Zhu, Diversity and abundance of arsenic biotransformation genes in paddy soils from southern China, Environmental Science \& Technology, 49 (2015) 4138-4146. 
[218] E. Moreno-Jiménez, E. Esteban, J.M. Peñalosa, The fate of arsenic in soil-plant systems, in: Reviews of environmental contamination and toxicology, Springer, 2012, pp. 1-37.

[219] M. Greger, Trace elements and radionuclides in edible plants, Trace Elements as Contaminants and Nutrients. John Wiley and Sons, Inc., Hoboken, NJ, (2008) 121-136.

[220] J.A. Verkleij, A. Golan-Goldhirsh, D.M. Antosiewisz, J.-P. Schwitzguébel, P. Schröder, Dualities in plant tolerance to pollutants and their uptake and translocation to the upper plant parts, Environmental and Experimental Botany, 67 (2009) 10-22.

[221] B.V. Tangahu, S. Abdullah, S. Rozaimah, H. Basri, M. Idris, N. Anuar, M. Mukhlisin, A review on heavy metals ( $\mathrm{As}, \mathrm{Pb}$, and $\mathrm{Hg}$ ) uptake by plants through phytoremediation, International Journal of Chemical Engineering, 2011 (2011).

[222] D. Gupta, S. Chatterjee, S. Datta, A. Voronina, C. Walther, Radionuclides: accumulation and transport in plants, in: Reviews of Environmental Contamination and Toxicology Volume 241, Springer, 2016, pp. 139-160.

[223] I. UdDin, A. Bano, S. Masood, Chromium toxicity tolerance of Solanum nigrum L. and Parthenium hysterophorus L. plants with reference to ion pattern, antioxidation activity and root exudation, Ecotoxicology and environmental safety, 113 (2015) 271-278.

[224] L. Hu, M.B. McBride, H. Cheng, J. Wu, J. Shi, J. Xu, L. Wu, Root-induced changes to cadmium speciation in the rhizosphere of two rice (Oryza sativa L.) genotypes, Environmental research, 111 (2011) 356-361.

[225] L.A. Weston, P.R. Ryan, M. Watt, Mechanisms for cellular transport and release of allelochemicals from plant roots into the rhizosphere, Journal of experimental botany, 63 (2012) 3445-3454.

[226] S. Lee, H.J. Jeong, S.A. Kim, J. Lee, M.L. Guerinot, G. An, OsZIP5 is a plasma membrane zinc transporter in rice, Plant molecular biology, 73 (2010) 507-517.

[227] T. Komal, M. Mustafa, Z. Ali, A.G. Kazi, Heavy metal uptake and transport in plants, in: Heavy metal contamination of soils, Springer, 2015, pp. 181-194. 
[228] M.J. Milner, J. Seamon, E. Craft, L.V. Kochian, Transport properties of members of the ZIP family in plants and their role in $\mathrm{Zn}$ and Mn homeostasis, Journal of experimental botany, 64 (2013) 369-381.

[229] G. Abbas, B. Murtaza, I. Bibi, M. Shahid, N. Niazi, M. Khan, M. Amjad, M. Hussain, Arsenic uptake, toxicity, detoxification, and speciation in plants: physiological, biochemical, and molecular aspects, International journal of environmental research and public health, 15 (2018) 59.

[230] J.M. Bastías, T. Beldarrain, Arsenic translocation in rice cultivation and its implication for human health, Chilean journal of agricultural research, 76 (2016) $114-122$

[231] J.F. Ma, N. Yamaji, Functions and transport of silicon in plants, Cellular and molecular life sciences, 65 (2008) 3049-3057.

[232] F.J. Zhao, J.F. Ma, A. Meharg, S. McGrath, Arsenic uptake and metabolism in plants, New Phytologist, 181 (2009) 777-794.

[233] P. Finnegan, W. Chen, Arsenic toxicity: the effects on plant metabolism, Frontiers in physiology, 3 (2012) 182.

[234] Y. Chen, Y.-H. Han, Y. Cao, Y.-G. Zhu, B. Rathinasabapathi, L.Q. Ma, Arsenic transport in rice and biological solutions to reduce arsenic risk from rice, Frontiers in Plant Science, 8 (2017) 268.

[235] H. Renkema, A. Koopmans, L. Kersbergen, J. Kikkert, B. Hale, E. Berkelaar, The effect of transpiration on selenium uptake and mobility in durum wheat and spring canola, Plant and Soil, 354 (2012) 239-250.

[236] L. Lin, W. Zhou, H. Dai, F. Cao, G. Zhang, F. Wu, Selenium reduces cadmium uptake and mitigates cadmium toxicity in rice, Journal of Hazardous Materials, 235 (2012) 343-351.

[237] L. Winkel, B. Vriens, G. Jones, L. Schneider, E. Pilon-Smits, G. Bañuelos, Selenium cycling across soil-plant-atmosphere interfaces: a critical review, Nutrients, 7 (2015) 4199-4239.

[238] D. Mazej, J. Osvald, V. Stibilj, Selenium species in leaves of chicory, dandelion, lamb's lettuce and parsley, Food Chemistry, 107 (2008) 75-83. 
[239] M.J. Hawkesford, L.J. De Kok, Managing sulphur metabolism in plants, Plant, Cell \& Environment, 29 (2006) 382-395.

[240] C. Bitterli, G. Bañuelos, R. Schulin, Use of transfer factors to characterize uptake of selenium by plants, Journal of Geochemical Exploration, 107 (2010) 206-216.

[241] E.A. Pilon-Smits, C.F. Quinn, Selenium metabolism in plants, in: Cell biology of metals and nutrients, Springer, 2010, pp. 225-241.

[242] S. Uraguchi, T. Fujiwara, Cadmium transport and tolerance in rice: perspectives for reducing grain cadmium accumulation, Rice, 5 (2012) 5.

[243] S. Lee, G. An, Over-expression of OsIRT1 leads to increased iron and zinc accumulations in rice, Plant, Cell \& Environment, 32 (2009) 408-416.

[244] S.A. Kim, M.L. Guerinot, Mining iron: iron uptake and transport in plants, FEBS letters, 581 (2007) 2273-2280.

[245] A. Sasaki, N. Yamaji, K. Yokosho, J.F. Ma, Nramp5 is a major transporter responsible for manganese and cadmium uptake in rice, The Plant Cell, 24 (2012) 2155-2167.

[246] S. Fujimaki, N. Suzui, N.S. Ishioka, N. Kawachi, S. Ito, M. Chino, S.-i. Nakamura, Tracing cadmium from culture to spikelet: noninvasive imaging and quantitative characterization of absorption, transport, and accumulation of cadmium in an intact rice plant, Plant physiology, 152 (2010) 1796-1806.

[247] W.-Y. Song, J. Park, C. Eisenach, M. Maeshima, Y. Lee, E. Martinoia, ABC transporters and heavy metals, in: Plant ABC Transporters, Springer, 2014, pp. $1-17$.

[248] S. Dutta, M. Mitra, P. Agarwal, K. Mahapatra, S. De, U. Sett, S. Roy, Oxidative and genotoxic damages in plants in response to heavy metal stress and maintenance of genome stability, Plant signaling \& behavior, 13 (2018) e1460048.

[249] A. Mani, K. Sankaranarayanan, Heavy Metal and Mineral Element-Induced Abiotic Stress in Rice Plant, Rice Crop: Current Developments, (2018) 149.

[250] H. Ahmadi, Functional analysis of the metal hyperaccumulation and hypertolerance candidate genes NAS4, ZIP6, CAX1 and NRAMP3 in Arabidopsis halleri, in, Universität Bayreuth, 2017. 
[251] E. Pinto, A.A. Aguiar, I.M. Ferreira, Influence of soil chemistry and plant physiology in the phytoremediation of $\mathrm{Cu}, \mathrm{Mn}$, and $\mathrm{Zn}$, Critical reviews in plant sciences, 33 (2014) 351-373.

[252] M. Tiwari, D. Sharma, S. Dwivedi, M. Singh, R.D. Tripathi, P.K. Trivedi, Expression in A rabidopsis and cellular localization reveal involvement of rice NRAMP, OsNRAMP 1, in arsenic transport and tolerance, Plant, Cell \& Environment, 37 (2014) 140-152.

[253] Y. Ishimaru, R. Takahashi, K. Bashir, H. Shimo, T. Senoura, K. Sugimoto, K. Ono, M. Yano, S. Ishikawa, T. Arao, Characterizing the role of rice NRAMP5 in manganese, iron and cadmium transport, Scientific reports, 2 (2012) 286.

[254] M. Shahid, S. Shamshad, M. Rafiq, S. Khalid, I. Bibi, N.K. Niazi, C. Dumat, M.I. Rashid, Chromium speciation, bioavailability, uptake, toxicity and detoxification in soil-plant system: A review, Chemosphere, 178 (2017) 513-533.

[255] S. Clemens, J.F. Ma, Toxic heavy metal and metalloid accumulation in crop plants and foods, Annual review of plant biology, 67 (2016) 489-512.

[256] Z.-Y. Hseu, S.-W. Su, H.-Y. Lai, H.-Y. Guo, T.-C. Chen, Z.-S. Chen, Remediation techniques and heavy metal uptake by different rice varieties in metalcontaminated soils of Taiwan: new aspects for food safety regulation and sustainable agriculture, Soil Science \& Plant Nutrition, 56 (2010) 31-52.

[257] F. Zeng, W. Wei, M. Li, R. Huang, F. Yang, Y. Duan, Heavy metal contamination in rice-producing soils of Hunan province, China and potential health risks, International journal of environmental research and public health, 12 (2015) 15584-15593.

[258] F. Zeng, S. Ali, H. Zhang, Y. Ouyang, B. Qiu, F. Wu, G. Zhang, The influence of $\mathrm{pH}$ and organic matter content in paddy soil on heavy metal availability and their uptake by rice plants, Environmental pollution, 159 (2011) 84-91.

[259] W.-X. Liu, L.-F. Shen, J.-W. Liu, Y.-W. Wang, S.-R. Li, Uptake of toxic heavy metals by rice (Oryza sativa L.) cultivated in the agricultural soil near Zhengzhou City, People's Republic of China, Bulletin of environmental contamination and toxicology, 79 (2007) 209-213. 
[260] C. Luo, R. Yang, Y. Wang, J. Li, G. Zhang, X. Li, Influence of agricultural practice on trace metals in soils and vegetation in the water conservation area along the East River (Dongjiang River), South China, Science of the Total Environment, 431 (2012) 26-32.

[261] C. Zhang, P. Wu, C. Tang, Z. Han, J. Sun, Assessment of arsenic distribution in paddy soil and rice plants of a typical karst basin affected by acid mine drainage in Southwest China, Environment and Pollution, 2 (2013) 27.

[262] G.-X. Sun, X. Liu, P.N. Williams, Y.-G. Zhu, Distribution and translocation of selenium from soil to grain and its speciation in paddy rice (Oryza sativa L.), Environmental Science \& Technology, 44 (2010) 6706-6711.

[263] T. Makino, Heavy metal pollution of soil and a new approach to its remediation: research experiences in Japan.

[264] T. Makino, Heavy metal pollution of soil and a new approach to its remediation: research experiences in Japan, Food and Fertilizer Technology Center, 2007.

[265] T. Arao, S. Ishikawa, M. Murakami, K. Abe, Y. Maejima, T. Makino, Heavy metal contamination of agricultural soil and countermeasures in Japan, Paddy and water Environment, 8 (2010) 247-257.

[266] S. Uraguchi, T. Fujiwara, Rice breaks ground for cadmium-free cereals, Current opinion in plant biology, 16 (2013) 328-334.

[267] K. Nogawa, E. Kobayashi, Y. Okubo, Y. Suwazono, Environmental cadmium exposure, adverse effects and preventive measures in Japan, Biometals, 17 (2004) 581-587.

[268] M. Abtahi, Y. Fakhri, G. Oliveri Conti, H. Keramati, Y. Zandsalimi, Z. Bahmani, R. Hosseini Pouya, M. Sarkhosh, B. Moradi, N. Amanidaz, Heavy metals (As, Cr, $\mathrm{Pb}, \mathrm{Cd}$ and $\mathrm{Ni}$ ) concentrations in rice (Oryza sativa) from Iran and associated risk assessment: a systematic review, Toxin reviews, 36 (2017) 331-341.

[269] D.A. Ahsan, T.A. DelValls, J. Blasco, Distribution of arsenic and trace metals in the floodplain agricultural soil of Bangladesh, Bulletin of environmental contamination and toxicology, 82 (2009) 11-15. 
[270] A.A. Meharg, M.M. Rahman, Arsenic contamination of Bangladesh paddy field soils: implications for rice contribution to arsenic consumption, Environmental Science \& Technology, 37 (2003) 229-234.

[271] P. Bhattacharya, A. Samal, J. Majumdar, S. Santra, Transfer of arsenic from groundwater and paddy soil to rice plant (Oryza sativa L.): a micro level study in West Bengal, India, World Journal of Agricultural Sciences, 5 (2009) 425-431.

[272] P. Kumarathilaka, S. Seneweera, A. Meharg, J. Bundschuh, Arsenic speciation dynamics in paddy rice soil-water environment: sources, physico-chemical, and biological factors-a review, Water research, 140 (2018) 403-414.

[273] Z. Cao, Z. Hu, Copper contamination in paddy soils irrigated with wastewater, Chemosphere, 41 (2000) 3-6.

[274] R.W. Simmons, A. Noble, P. Pongsakul, O. Sukreeyapongse, N. Chinabut, Analysis of field-moist $\mathrm{Cd}$ contaminated paddy soils during rice grain fill allows reliable prediction of grain Cd levels, Plant and Soil, 302 (2008) 125-137.

[275] S. Gupta, S. Nayek, R. Saha, S. Satpati, Assessment of heavy metal accumulation in macrophyte, agricultural soil, and crop plants adjacent to discharge zone of sponge iron factory, Environmental geology, 55 (2008) 731-739.

[276] M. Shahid, C. Dumat, S. Khalid, E. Schreck, T. Xiong, N.K. Niazi, Foliar heavy metal uptake, toxicity and detoxification in plants: A comparison of foliar and root metal uptake, Journal of Hazardous Materials, 325 (2017) 36-58.

[277] J. Feng, Y. Wang, J. Zhao, L. Zhu, X. Bian, W. Zhang, Source attributions of heavy metals in rice plant along highway in Eastern China, Journal of Environmental Sciences, 23 (2011) 1158-1164.

[278] S. Xia, Z. Song, P. Jeyakumar, S.M. Shaheen, J. Rinklebe, Y.S. Ok, N. Bolan, H. Wang, A critical review on bioremediation technologies for $\mathrm{Cr}(\mathrm{VI})$-contaminated soils and wastewater, Critical Reviews in Environmental Science and Technology, 49 (2019) 1027-1078.

[279] S. Khalid, M. Shahid, N.K. Niazi, B. Murtaza, I. Bibi, C. Dumat, A comparison of technologies for remediation of heavy metal contaminated soils, Journal of Geochemical Exploration, 182 (2017) 247-268. 
[280] Z. Yao, J. Li, H. Xie, C. Yu, Review on remediation technologies of soil contaminated by heavy metals, Procedia Environmental Sciences, 16 (2012) 722729.

[281] Z.D. Nejad, M.C. Jung, K.-H. Kim, Remediation of soils contaminated with heavy metals with an emphasis on immobilization technology, Environmental Geochemistry and Health, 40 (2018) 927-953.

[282] B. Kendall, T.W. Dahl, A.D. Anbar, The stable isotope geochemistry of molybdenum, Reviews in Mineralogy and Geochemistry, 82 (2017) 683-732.

[283] J.R. Koduru, S. Shankar, N.S. More, L.P. Shikha, Approaches for Environmental Cleanup.

[284] A.P. Marques, A.O. Rangel, P.M. Castro, Remediation of heavy metal contaminated soils: phytoremediation as a potentially promising clean-up technology, Critical Reviews in Environmental Science and Technology, 39 (2009) 622-654.

[285] A.P. Marques, A.O. Rangel, P.M. Castro, Remediation of heavy metal contaminated soils: an overview of site remediation techniques, Critical Reviews in Environmental Science and Technology, 41 (2011) 879-914.

[286] F.A. Caliman, B.M. Robu, C. Smaranda, V.L. Pavel, M. Gavrilescu, Soil and groundwater cleanup: benefits and limits of emerging technologies, Clean Technologies and Environmental Policy, 13 (2011) 241-268.

[287] Y. Gong, D. Zhao, Q. Wang, An overview of field-scale studies on remediation of soil contaminated with heavy metals and metalloids: technical progress over the last decade, Water research, 147 (2018) 440-460.

[288] O. Rodríguez, I. Padilla, H. Tayibi, A. López-Delgado, Concerns on liquid mercury and mercury-containing wastes: A review of the treatment technologies for the safe storage, Journal of Environmental Management, 101 (2012) 197-205.

[289] J.P. Chen, L.K. Wang, M.-H.S. Wang, Y.-T. Hung, N.K. Shammas, Remediation of heavy metals in the environment, Crc Press, 2016.

[290] N. Habibul, Y. Hu, G.-P. Sheng, Microbial fuel cell driving electrokinetic remediation of toxic metal contaminated soils, Journal of Hazardous Materials, 318 (2016) 9-14. 
[291] M. Vocciante, A. Caretta, L. Bua, R. Bagatin, S. Ferro, Enhancements in ElectroKinetic Remediation Technology: Environmental assessment in comparison with other configurations and consolidated solutions, Chemical Engineering Journal, 289 (2016) 123-134.

[292] C.S. Lwin, B.-H. Seo, H.-U. Kim, G. Owens, K.-R. Kim, Application of soil amendments to contaminated soils for heavy metal immobilization and improved soil quality—a critical review, Soil science and plant nutrition, 64 (2018) 156-167.

[293] M.A. Soares, M.J. Quina, R.M. Quinta-Ferreira, Immobilisation of lead and zinc in contaminated soil using compost derived from industrial eggshell, Journal of Environmental Management, 164 (2015) 137-145.

[294] I. Smičiklas, S. Smiljanić, A. Perić-Grujić, M. Šljivić-Ivanović, M. Mitrić, D. Antonović, Effect of acid treatment on red mud properties with implications on $\mathrm{Ni}$ (II) sorption and stability, Chemical Engineering Journal, 242 (2014) 27-35.

[295] F.-J. Zhao, Y. Ma, Y.-G. Zhu, Z. Tang, S.P. McGrath, Soil contamination in China: current status and mitigation strategies, Environmental Science \& Technology, 49 (2015) 750-759.

[296] X. Cao, L. Ma, Y. Liang, B. Gao, W. Harris, Simultaneous immobilization of lead and atrazine in contaminated soils using dairy-manure biochar, Environmental Science \& Technology, 45 (2011) 4884-4889.

[297] C.B. France, Method of encapsulating waste, in, Google Patents, 2015.

[298] G. Dermont, M. Bergeron, G. Mercier, M. Richer-Laflèche, Soil washing for metal removal: a review of physical/chemical technologies and field applications, Journal of Hazardous Materials, 152 (2008) 1-31.

[299] D. Leštan, C.-1. Luo, X.-d. Li, The use of chelating agents in the remediation of metal-contaminated soils: a review, Environmental pollution, 153 (2008) 3-13.

[300] Z.A. Begum, I.M. Rahman, H. Sawai, H. Hasegawa, Chemical-induced washing remediation of metal-contaminated soils, in: Environmental Remediation Technologies for Metal-Contaminated Soils, Springer, 2016, pp. 197-218.

[301] O. Apori, E. Hanyabui, Y. Asiamah, Remediation Technology for Copper Contaminated Soil: A Review, Asian Soil Research Journal, (2018) 1-7. 
[302] G.U. Chibuike, S.C. Obiora, Heavy metal polluted soils: effect on plants and bioremediation methods, Applied and Environmental Soil Science, 2014 (2014).

[303] D. Sivakumar, A. Kandaswamy, V. Gomathi, R. Rajeshwaran, N. Murugan, Bioremediation studies on reduction of heavy metals toxicity, Pollution Research, 33 (2014) 553-558.

[304] K.K. Yadav, N. Gupta, A. Kumar, L.M. Reece, N. Singh, S. Rezania, S.A. Khan, Mechanistic understanding and holistic approach of phytoremediation: a review on application and future prospects, Ecological engineering, 120 (2018) 274-298.

[305] S.H. Awa, T. Hadibarata, Removal of Heavy Metals in Contaminated Soil by Phytoremediation Mechanism: a Review, Water, Air, \& Soil Pollution, 231 (2020) 47.

[306] H. Singh, A. Verma, M. Kumar, R. Sharma, R. Gupta, M. Kaur, M. Negi, S. Sharma, Phytoremediation: a green technology to clean up the sites with low and moderate level of heavy metals, Austin Biochem, 2 (2017) 1012.

[307] P.S. Kumar, E. Gunasundari, Bioremediation of heavy metals, in: Bioremediation: Applications for Environmental Protection and Management, Springer, 2018, pp. 165-195.

[308] A. Mahar, P. Wang, A. Ali, M.K. Awasthi, A.H. Lahori, Q. Wang, R. Li, Z. Zhang, Challenges and opportunities in the phytoremediation of heavy metals contaminated soils: a review, Ecotoxicology and environmental safety, 126 (2016) 111-121.

[309] N. Sarwar, M. Imran, M.R. Shaheen, W. Ishaque, M.A. Kamran, A. Matloob, A. Rehim, S. Hussain, Phytoremediation strategies for soils contaminated with heavy metals: modifications and future perspectives, Chemosphere, 171 (2017) 710-721.

[310] N.S. Bolan, J.H. Park, B. Robinson, R. Naidu, K.Y. Huh, Phytostabilization: a green approach to contaminant containment, in: Advances in agronomy, Elsevier, 2011, pp. 145-204.

[311] A. Pinto, A. De Varennes, R. Fonseca, D.M. Teixeira, Phytoremediation of soils contaminated with heavy metals: techniques and strategies, in: Phytoremediation, Springer, 2015, pp. 133-155. 
[312] F.M. Tack, E. Meers, Assisted phytoextraction: helping plants to help us, Elements, 6 (2010) 383-388.

[313] M.A. Galende, J.M. Becerril, O. Barrutia, U. Artetxe, C. Garbisu, A. Hernández, Field assessment of the effectiveness of organic amendments for aided phytostabilization of a $\mathrm{Pb}-\mathrm{Zn}$ contaminated mine soil, Journal of Geochemical Exploration, 145 (2014) 181-189.

[314] M. Laghlimi, B. Baghdad, H.E. Hadi, A. Bouabdli, Phytoremediation mechanisms of heavy metal contaminated soils: a review, (2015).

[315] H. Ali, E. Khan, M.A. Sajad, Phytoremediation of heavy metals-concepts and applications, Chemosphere, 91 (2013) 869-881.

[316] X. Wan, M. Lei, T. Chen, Cost-benefit calculation of phytoremediation technology for heavy-metal-contaminated soil, Science of the Total Environment, 563 (2016) 796-802.

[317] A. Bhargava, F.F. Carmona, M. Bhargava, S. Srivastava, Approaches for enhanced phytoextraction of heavy metals, Journal of Environmental Management, 105 (2012) 103-120.

[318] M.A. Hashim, S. Mukhopadhyay, J.N. Sahu, B. Sengupta, Remediation technologies for heavy metal contaminated groundwater, Journal of Environmental Management, 92 (2011) 2355-2388.

[319] R.L. Chaney, J.S. Angle, C.L. Broadhurst, C.A. Peters, R.V. Tappero, D.L. Sparks, Improved understanding of hyperaccumulation yields commercial phytoextraction and phytomining technologies, Journal of environmental quality, 36 (2007) 1429-1443.

[320] S. Clemens, Toxic metal accumulation, responses to exposure and mechanisms of tolerance in plants, Biochimie, 88 (2006) 1707-1719.

[321] P.K. Padmavathiamma, L.Y. Li, Phytoremediation technology: hyperaccumulation metals in plants, Water, Air, and Soil Pollution, 184 (2007) 105126.

[322] M.A. da Conceição Gomes, R.A. Hauser-Davis, A.N. de Souza, A.P. Vitória, Metal phytoremediation: General strategies, genetically modified plants and 
applications in metal nanoparticle contamination, Ecotoxicology and environmental safety, 134 (2016) 133-147.

[323] S. Thakur, L. Singh, Z. Ab Wahid, M.F. Siddiqui, S.M. Atnaw, M.F.M. Din, Plantdriven removal of heavy metals from soil: uptake, translocation, tolerance mechanism, challenges, and future perspectives, Environmental monitoring and assessment, 188 (2016) 206.

[324] X. Yang, Y. Feng, Z. He, P.J. Stoffella, Molecular mechanisms of heavy metal hyperaccumulation and phytoremediation, Journal of Trace elements in Medicine and Biology, 18 (2005) 339-353.

[325] S.S. Kumar, A. Kadier, S.K. Malyan, A. Ahmad, N.R. Bishnoi, Phytoremediation and rhizoremediation: uptake, mobilization and sequestration of heavy metals by plants, in: Plant-microbe interactions in agro-ecological perspectives, Springer, 2017, pp. 367-394.

[326] G. Guo, F. Wu, F. Xie, R. Zhang, Spatial distribution and pollution assessment of heavy metals in urban soils from southwest China, Journal of Environmental Sciences, 24 (2012) 410-418.

[327] Y. Barrameda-Medina, D. Montesinos-Pereira, L. Romero, J.M. Ruiz, B. Blasco, Comparative study of the toxic effect of $\mathrm{Zn}$ in Lactuca sativa and Brassica oleracea plants: I. Growth, distribution, and accumulation of $\mathrm{Zn}$, and metabolism of carboxylates, Environmental and Experimental Botany, 107 (2014) 98-104.

[328] H. Khoudi, Y. Maatar, F. Brini, A. Fourati, N. Ammar, K. Masmoudi, Phytoremediation potential of Arabidopsis thaliana, expressing ectopically a vacuolar proton pump, for the industrial waste phosphogypsum, Environmental Science and Pollution Research, 20 (2013) 270-280.

[329] C. Gisbert, R. Ros, A. De Haro, D.J. Walker, M.P. Bernal, R. Serrano, J. NavarroAviñó, A plant genetically modified that accumulates $\mathrm{Pb}$ is especially promising for phytoremediation, Biochemical and biophysical research communications, 303 (2003) 440-445.

[330] A.S. Ayangbenro, O.O. Babalola, A new strategy for heavy metal polluted environments: a review of microbial biosorbents, International journal of environmental research and public health, 14 (2017) 94. 
[331] A. Pinto, A. de Varennes, C. Dias, M. Lopes, Microbial-Assisted Phytoremediation: A Convenient Use of Plant and Microbes to Clean Up Soils, in: Phytoremediation, Springer, 2018, pp. 21-87.

[332] B.R. Glick, Bacteria with ACC deaminase can promote plant growth and help to feed the world, Microbiological research, 169 (2014) 30-39.

[333] A. Cuypers, T. Remans, N. Weyens, J. Colpaert, A. Vassilev, J. Vangronsveld, Soil-plant relationships of heavy metals and metalloids, in: Heavy metals in soils, Springer, 2013, pp. 161-193.

[334] Z. Yang, Z. Zhang, L. Chai, Y. Wang, Y. Liu, R. Xiao, Bioleaching remediation of heavy metal-contaminated soils using Burkholderia sp. Z-90, Journal of Hazardous Materials, 301 (2016) 145-152.

[335] Y. Ma, R.S. Oliveira, F. Nai, M. Rajkumar, Y. Luo, I. Rocha, H. Freitas, The hyperaccumulator Sedum plumbizincicola harbors metal-resistant endophytic bacteria that improve its phytoextraction capacity in multi-metal contaminated soil, Journal of Environmental Management, 156 (2015) 62-69.

[336] Y. Ma, M. Prasad, M. Rajkumar, H. Freitas, Plant growth promoting rhizobacteria and endophytes accelerate phytoremediation of metalliferous soils, Biotechnology advances, 29 (2011) 248-258.

[337] H.I. Tak, F. Ahmad, O.O. Babalola, Advances in the application of plant growthpromoting rhizobacteria in phytoremediation of heavy metals, in: Reviews of Environmental Contamination and Toxicology Volume 223, Springer, 2013, pp. $33-52$.

[338] C. de la Fuente, R. Clemente, I. Martínez-Alcalá, G. Tortosa, M.P. Bernal, Impact of fresh and composted solid olive husk and their water-soluble fractions on soil heavy metal fractionation; microbial biomass and plant uptake, Journal of Hazardous Materials, 186 (2011) 1283-1289.

[339] A. Sessitsch, M. Kuffner, P. Kidd, J. Vangronsveld, W.W. Wenzel, K. Fallmann, M. Puschenreiter, The role of plant-associated bacteria in the mobilization and phytoextraction of trace elements in contaminated soils, Soil Biology and Biochemistry, 60 (2013) 182-194. 
[340] K. Zhao, W. Fu, Z. Ye, C. Zhang, Contamination and spatial variation of heavy metals in the soil-rice system in Nanxun County, Southeastern China, International journal of environmental research and public health, 12 (2015) 15771594.

[341] X. Cheng, J. Drozdova, T. Danek, Q. Huang, W. Qi, S. Yang, L. Zou, Y. Xiang, X. Zhao, Pollution Assessment of Trace Elements in Agricultural Soils around Copper Mining Area, Sustainability, 10 (2018) 4533.

[342] T. Dang, P. Nguyen, D. Nguyen, Soil pollution with heavy metals in the some areas in Vietnam, Vietnam Soil Sci J, 29 (2008) 59-62.

[343] M. Singh, V. Garg, Y. Gautam, A. Kumar, Soil to grain transfer factors of heavy metals in rice and health risk analysis in the vicinity of Narora Atomic Power Station (NAPS), Narora, India, (2014).

[344] P. Yadav, B. Singh, V. Garg, S. Mor, V. Pulhani, Bioaccumulation and health risks of heavy metals associated with consumption of rice grains from croplands in Northern India, Human and Ecological Risk Assessment: An International Journal, 23 (2017) 14-27.

[345] D. Yap, J. Adezrian, J. Khairiah, B. Ismail, R. Ahmad-Mahir, The uptake of heavy metals by paddy plants (Oryza sativa) in Kota Marudu, Sabah, Malaysia, Am Eurasian J Agric Environ Sci, 6 (2009) 16-19.

[346] T. Makino, Y. Luo, L. Wu, Y. SAKURAI, Y. MAEJIMA, I. AKAHANE, T. ARAO, Heavy Metal Pollution of Soil and Risk Alleviation Methods Based on Soil Chemistry (< Special Issue> International Symposium: Challenges to Soil Degradation Towards Sustaining Life and Environment, Tokyo Metropolitan University Symposium Series No. 2, 2009), Pedologist, 53 (2010) 38-49.

[347] H. Tsukada, H. Hasegawa, A. Takeda, S. Hisamatsu, Concentrations of major and trace elements in polished rice and paddy soils collected in Aomori, Japan, Journal of radioanalytical and nuclear chemistry, 273 (2007) 199-203.

[348] K.S. Dhillon, S.K. Dhillon, Genesis of seleniferous soils and associated animal and human health problems, (2018). 
[349] I. Jo, M. Koh, Chemical changes in agricultural soils of Korea: data review and suggested countermeasures, Environmental Geochemistry and Health, 26 (2004) 105-117.

[350] S.R. Tariq, N. Rashid, Multivariate analysis of metal levels in paddy soil, rice plants, and rice grains: a case study from Shakargarh, Pakistan, Journal of Chemistry, 2013 (2012).

[351] N. Chinoim, N. Sinbuathong, Heavy metal contamination of soils from organic paddy fields in Thailand, in: 19th World Congress of Soil Science, Soil Solutions for a Changing World held on, 2010, pp. 1-6.

[352] K. Zhao, W. Zhang, L. Zhou, X. Liu, J. Xu, P. Huang, Modeling transfer of heavy metals in soil-rice system and their risk assessment in paddy fields, Environmental earth sciences, 59 (2009) 519-527.

[353] Z. Huang, X.-D. Pan, P.-G. Wu, J.-L. Han, Q. Chen, Health risk assessment of heavy metals in rice to the population in Zhejiang, China, PloS one, 8 (2013) e75007.

[354] H. Zhang, X. Feng, C. Jiang, Q. Li, Y. Liu, C. Gu, L. Shang, P. Li, Y. Lin, T. Larssen, Understanding the paradox of selenium contamination in mercury mining areas: High soil content and low accumulation in rice, Environmental pollution, 188 (2014) 27-36.

[355] Z. Cao, X. Wang, D. Yao, X. Zhang, M. Wong, Selenium geochemistry of paddy soils in Yangtze River Delta, Environment international, 26 (2001) 335-339.

[356] H. Zhang, X. Feng, J. Zhu, A. Sapkota, B. Meng, H. Yao, H. Qin, T. Larssen, Selenium in soil inhibits mercury uptake and translocation in rice (Oryza sativa L.), Environmental Science \& Technology, 46 (2012) 10040-10046.

[357] W. Sun, B. Huang, Y. Zhao, X. Shi, J.L. Darilek, X. Deng, H. Wang, Z. Zou, Spatial variability of soil selenium as affected by geologic and pedogenic processes and its effect on ecosystem and human health, Geochemical Journal, 43 (2009) 217225.

[358] T. Roychowdhury, H. Tokunaga, M. Ando, Survey of arsenic and other heavy metals in food composites and drinking water and estimation of dietary intake by 
the villagers from an arsenic-affected area of West Bengal, India, Science of the Total Environment, 308 (2003) 15-35.

[359] M.A. Rahman, M.M. Rahman, S.M. Reichman, R.P. Lim, R. Naidu, Heavy metals in Australian grown and imported rice and vegetables on sale in Australia: health hazard, Ecotoxicology and environmental safety, 100 (2014) 53-60.

[360] J.L. Stroud, G.J. Norton, M.R. Islam, T. Dasgupta, R.P. White, A.H. Price, A.A. Meharg, S.P. McGrath, F.-J. Zhao, The dynamics of arsenic in four paddy fields in the Bengal delta, Environmental pollution, 159 (2011) 947-953.

[361] A.M. Shraim, Rice is a potential dietary source of not only arsenic but also other toxic elements like lead and chromium, Arabian Journal of Chemistry, 10 (2017) S3434-S3443.

[362] A. Jafari, B. Kamarehie, M. Ghaderpoori, N. Khoshnamvand, M. Birjandi, The concentration data of heavy metals in Iranian grown and imported rice and human health hazard assessment, Data in brief, 16 (2018) 453-459.

[363] F. Asgari, M. HAGHAZALI, H. HEYDARIAN, Non-communicable diseases risk factors surveillance in Iran, (2009).

[364] J. Singh, S.K. Upadhyay, R.K. Pathak, V. Gupta, Accumulation of heavy metals in soil and paddy crop (Oryza sativa), irrigated with water of Ramgarh Lake, Gorakhpur, UP, India, Toxicological \& Environmental Chemistry, 93 (2011) 462473.

[365] M. Kibria, M. Islam, M. Alamgir, Influence of waste water irrigation on heavy metal accumulation in soil and plant, Int. J. Appl. Nat. Sci, 1 (2012) 43-54.

[366] H. Cao, J. Chen, J. Zhang, H. Zhang, L. Qiao, Y. Men, Heavy metals in rice and garden vegetables and their potential health risks to inhabitants in the vicinity of an industrial zone in Jiangsu, China, Journal of Environmental Sciences, 22 (2010) 1792-1799.

[367] Z. Liu, Q. Zhang, T. Han, Y. Ding, J. Sun, F. Wang, C. Zhu, Heavy metal pollution in a soil-rice system in the Yangtze river region of China, International journal of environmental research and public health, 13 (2016) 63. 


\section{List of figures}

Fig. 1. A general overview of natural, anthropogenic sources of trace elements in environmental matrices, and associated human health toxicities.

Fig. 2. The uptake, translocation, and accumulation mechanism of trace elements, (a) arsenic, (b) selenium, (c) cadmium, (d) lead, (e) zinc, (f) manganese (g) nickel, and (h) chromium in paddy soil-rice system.

Fig. 3. Trace element arsenic (As), selenium (Se), cadmium $(\mathrm{Cd})$, lead ( $\mathrm{Pb})$, zinc $(\mathrm{Zn})$ manganese $(\mathrm{Mn})$, nickel $(\mathrm{Ni})$, and chromium $(\mathrm{Cr})$ contamination in grains of major rice-growing countries.

Fig. 4. Comparison of soil management/remediation methods for trace elements-contaminated soils. 


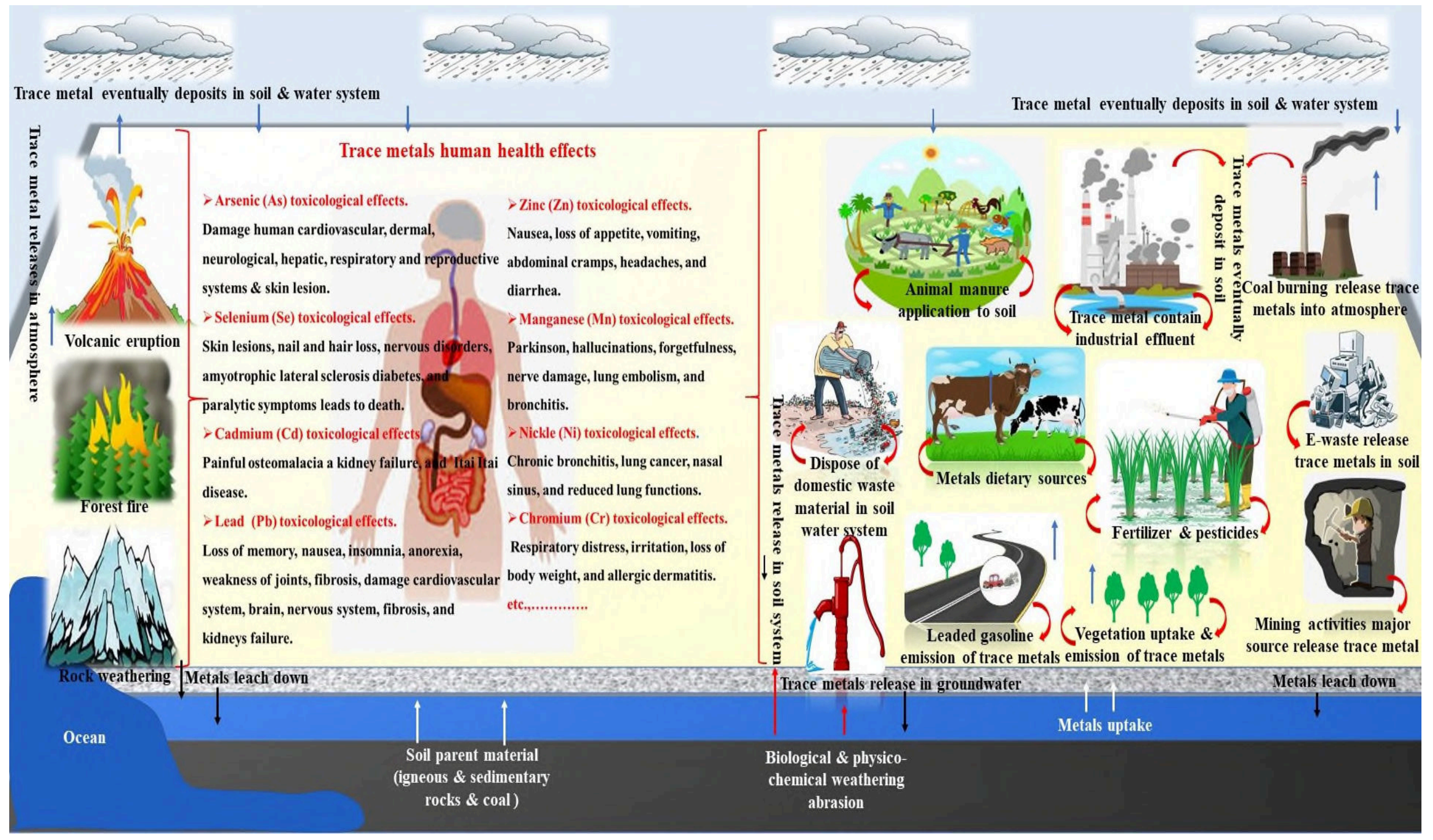

Fig. 1. 
(a)

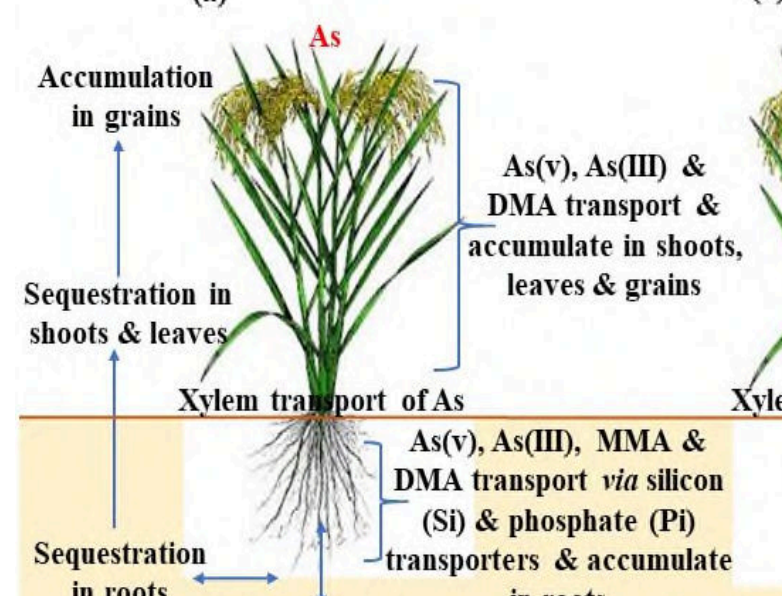

in roots

Available organic

As uptake from soil

(e)

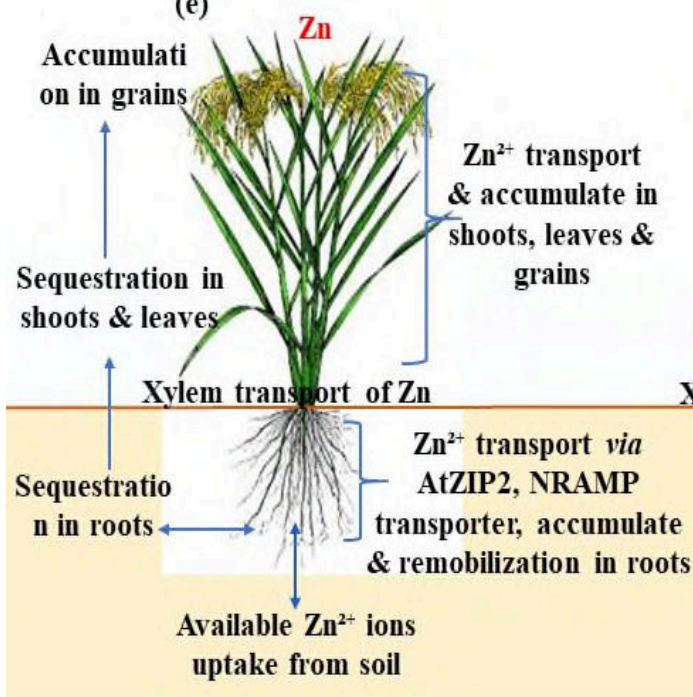

(b) (c)

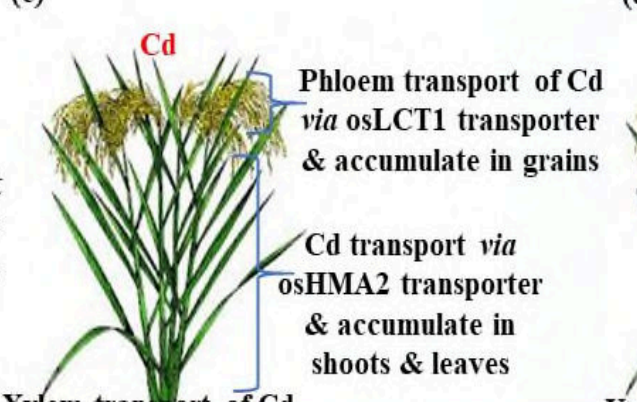

(d)

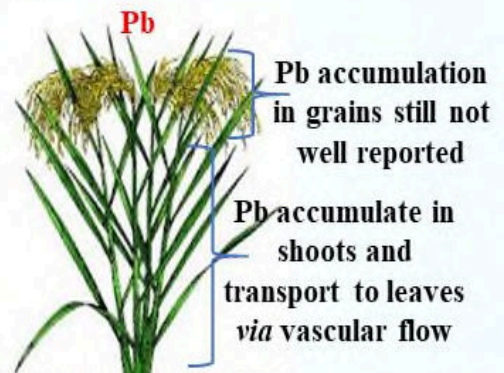

Xylem transport of $\mathbf{P b}$

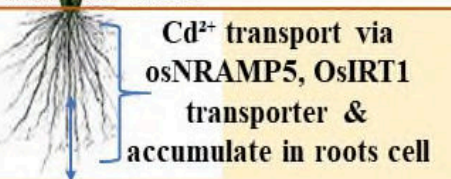

Available $\mathrm{Cd}^{2+}$ ions uptake from soil uptake from soil

(g) $\mathrm{Ni}$

(f) $\mathrm{Mn}$

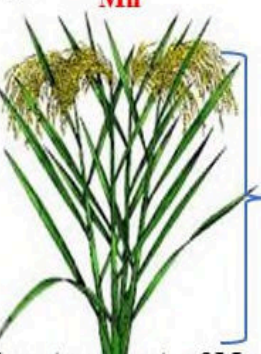

$\mathrm{Mn}^{2+}$ transport \& accumulate in shoots, leaves \& grains

Xylem transport of Mn
$\begin{gathered}\mathrm{Mn}^{2+} \text { transport via } \\ \text { AtZIP1, NRAMP5 } \\ \text { transporter, accumulate } \\ \text { \&remobilization in roots }\end{gathered}$
uvailable $\mathrm{Mn}^{2+}$ ions
uptake from soil

$\mathrm{Ni}^{2+}$ transport \& accumulate in shoots, leaves \& grains

Xylem tran port of $\mathrm{Ni}$ grains $\mathrm{Pb}^{2+}$ transport via protons
pump, (H+ ATPase and
$\mathrm{H}+$ ) \& $\mathrm{ABC}$ transporter
$\&$ accumulate in roots Available $\mathbf{P b}^{2+}$ ions uptake from soil

(h)

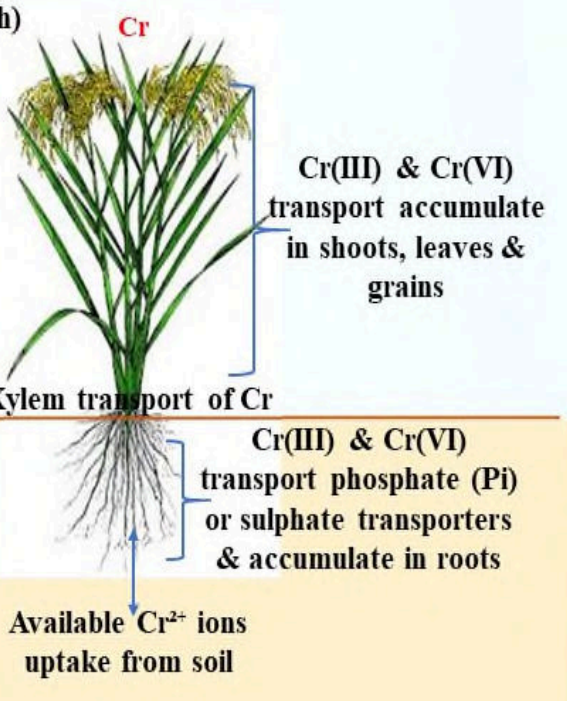

Fig. 2. 


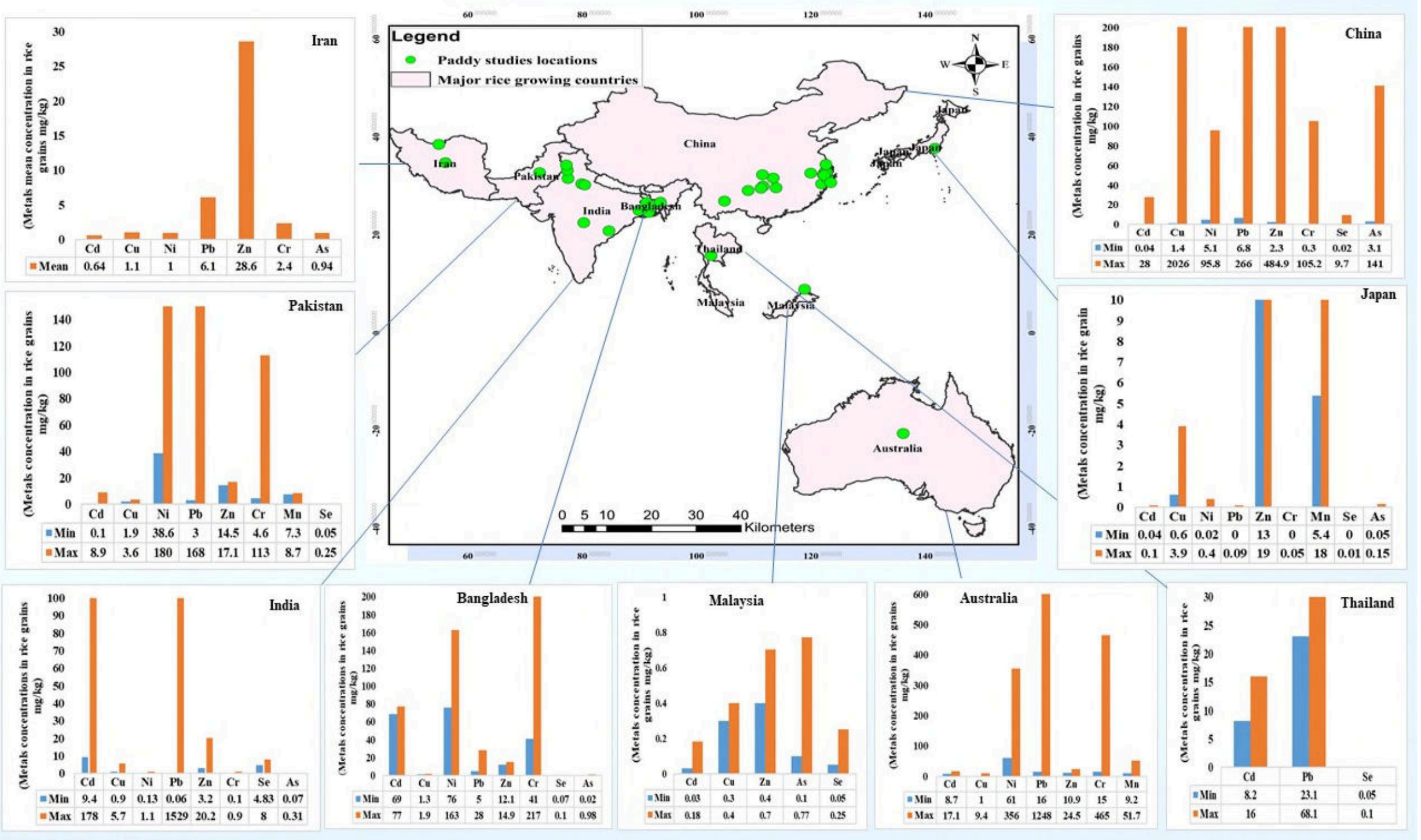

Fig. 3. 


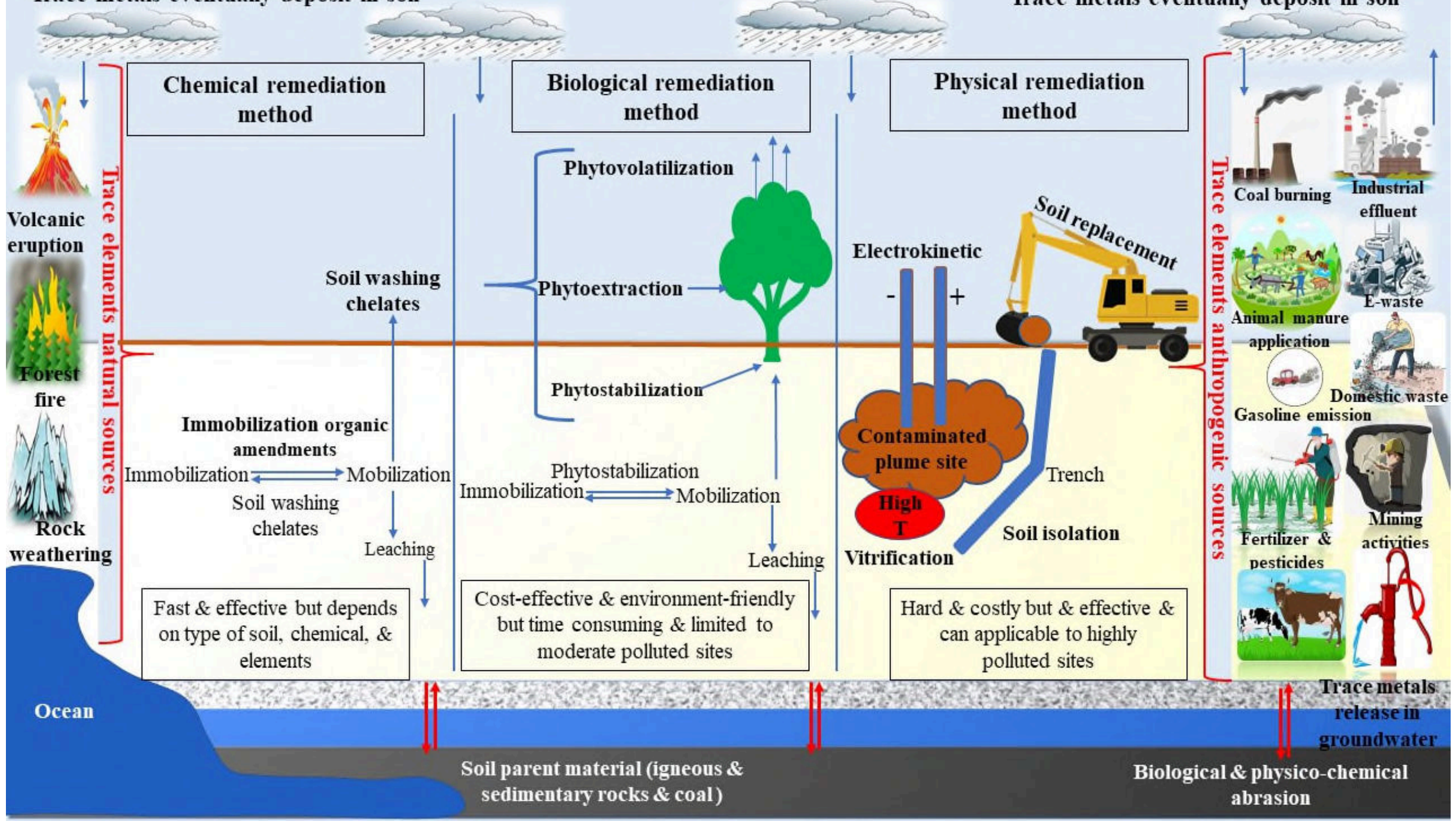

Fig. 4. 


\section{List of tables}

Table 1 Reported trace element concentrations ranges minimum-maximum (mean) $\mathrm{mg} / \mathrm{kg}$ in paddy soils of different countries.

Table 2 Reported trace element concentrations ranges minimum-maximum (mean) $\mathrm{mg} / \mathrm{kg}$ in grain in different countries.

Table 3 Trace element content and translocation factor (TF) from paddy soil to different parts (roots, shoots, \& grains) of the rice plant. 
Table 1 Reported trace element concentrations ranges minimum-maximum (mean) $\mathbf{m g} / \mathrm{kg}$ in paddy soils of different countries.

\begin{tabular}{|c|c|c|c|c|c|c|c|c|c|c|c|}
\hline Country & Locations & Cd & $\mathrm{Cu}$ & $\mathbf{N i}$ & $\mathbf{P b}$ & Zn & $\mathrm{Cr}$ & Mn & Se & As & Reference \\
\hline \multirow{13}{*}{ China } & Wenling & $\begin{array}{c}0.11-3.45 \\
(0.31)\end{array}$ & $\begin{array}{c}15.8-160.1 \\
(41.1)\end{array}$ & $\begin{array}{c}9.2-68.2 \\
(33.9)\end{array}$ & $\begin{array}{c}27.1-140.5 \\
(48.30)\end{array}$ & $\begin{array}{c}64.97-276.0 \\
(137.0)\end{array}$ & - & - & - & - & {$[3]$} \\
\hline & Shengzou & $\begin{array}{c}0.04-0.28 \\
(0.1)\end{array}$ & $\begin{array}{c}15.1-78.1 \\
(29.8)\end{array}$ & $\begin{array}{l}5.1-62.7 \\
(19.2)\end{array}$ & $\begin{array}{c}22.0-50.4 \\
(34.3)\end{array}$ & $\begin{array}{c}34.7-113.6 \\
(75.8)\end{array}$ & $\begin{array}{c}15.1-78.1 \\
(29.8)\end{array}$ & - & - & - & $\begin{array}{l}\text { (Zhao et } \\
\text { al., } 2009\end{array}$ \\
\hline & Nanxun & $\begin{array}{c}0.12-0.78 \\
(0.2)\end{array}$ & $\begin{array}{c}18.8-82.3 \\
(31.1)\end{array}$ & $\begin{array}{l}18.5-55.6 \\
(32.1)\end{array}$ & $\begin{array}{l}20.2-51.7 \\
(33.2)\end{array}$ & $\begin{array}{c}61.5-266.9 \\
(106.8)\end{array}$ & - & - & - & - & [340] \\
\hline & Kunming & $\begin{array}{l}0.20-3.57 \\
\quad(1.1)\end{array}$ & $\begin{array}{c}(45.4-2026 \\
(152.7)\end{array}$ & $\begin{array}{c}24.1-95.8 \\
(45.0)\end{array}$ & $\begin{array}{l}6.8-146.6 \\
(42.2)\end{array}$ & $\begin{array}{l}55.8-484.9 \\
(203.3)\end{array}$ & $\begin{array}{c}(52.0-105.2 \\
\quad(73.4)\end{array}$ & - & - & $\begin{array}{l}(10.0- \\
141.5 \\
(24.4)\end{array}$ & [341] \\
\hline & Hunan & $\begin{array}{c}0.17-27.3 \\
(1.1)\end{array}$ & - & - & $\begin{array}{l}24.8-266.0 \\
\quad(52.9)\end{array}$ & - & - & - & - & $\begin{array}{c}(7.3-124.0 \\
(19.5)\end{array}$ & {$[4]$} \\
\hline & Nanhu & - & $\begin{array}{c}6.6-8.0 \\
(7.3)\end{array}$ & - & $\begin{array}{c}11.0-12.0 \\
(11.4)\end{array}$ & $\begin{array}{c}4.7-11.4 \\
(7.7)\end{array}$ & $\begin{array}{c}0.6-1.1 \\
(0.8)\end{array}$ & - & - & $x^{2}+2$ & \multirow{3}{*}{ [258] } \\
\hline & Tongxiang & - & $\begin{array}{c}5.26-9.70 \\
(7.0)\end{array}$ & - & $\begin{array}{c}9.1-17.8 \\
(12.6)\end{array}$ & $\begin{array}{l}2.26-6.94 \\
(3.9)\end{array}$ & $\begin{array}{c}0.5-0.7 \\
(0.6)\end{array}$ & - & - & - & \\
\hline & Xiaoshan & - & $\begin{array}{c}1.38-5.66 \\
(3.7)\end{array}$ & - & $\begin{array}{c}2.0-9.74 \\
(5.1)\end{array}$ & $\begin{array}{c}1.40-12.2 \\
(5.7)\end{array}$ & $\begin{array}{c}0.3-0.8 \\
(0.6)\end{array}$ & - & - & - & \\
\hline & Shimen & $\begin{array}{c}0.06-0.4 \\
(0.2)\end{array}$ & (क्र & $\begin{array}{c}26.6-48.7 \\
(36.2)\end{array}$ & $\begin{array}{c}19.8-32.3 \\
(24.9)\end{array}$ & (1- & $\begin{array}{c}23.2-33.5 \\
(26.0)\end{array}$ & - & - & $\begin{array}{c}3.16-45.2 \\
(22.1)\end{array}$ & \multirow{3}{*}{ [257] } \\
\hline & Fenghuang & $\begin{array}{c}0.04-28.0 \\
(3.3)\end{array}$ & - & $\begin{array}{c}25.9-44.5 \\
(36.5)\end{array}$ & $\begin{array}{c}19.6-83.6 \\
(43.3)\end{array}$ & - & $\begin{array}{c}21.5-28.2 \\
(23.7)\end{array}$ & - & - & $\begin{array}{c}12.2-34.8 \\
(21.2)\end{array}$ & \\
\hline & Xiangtan & $\begin{array}{c}0.18-1.17 \\
(0.5)\end{array}$ & - & $\begin{array}{c}14.9-40.0 \\
(27.7)\end{array}$ & $\begin{array}{l}37.7-262.0 \\
(94.5)\end{array}$ & - & $\begin{array}{c}28.1-39.3 \\
(33.1)\end{array}$ & - & - & $\begin{array}{c}3.3-6.3 \\
(4.5)\end{array}$ & \\
\hline & Tan Long & $2.3-42.9$ & - & - & $1271-3953$ & - & - & - & - & - & [342] \\
\hline & Chi Dao & $2.5-56.5$ & - & - & $2000-10000$ & - & - & - & - & - & [101] \\
\hline \multirow{3}{*}{ Bangladesh } & Faridpur & $\begin{array}{l}0.12-0.17 \\
\quad(0.2)\end{array}$ & $\begin{array}{c}38.2-63.5 \\
(48.4)\end{array}$ & $\begin{array}{c}42.2-61.0 \\
(48.8)\end{array}$ & $\begin{array}{l}24.32-34.0 \\
(26.8)\end{array}$ & $\begin{array}{l}82.7-117.4 \\
\quad(97.2)\end{array}$ & $\begin{array}{c}73.5-108.1 \\
(86.0)\end{array}$ & $\begin{array}{c}374.1-575.2 \\
(449.7)\end{array}$ & $\begin{array}{c}(0.6- \\
1.4 \\
(1.0)\end{array}$ & $\begin{array}{c}17.4-65.0 \\
(33.1)\end{array}$ & \multirow{2}{*}{ [269] } \\
\hline & Dhamrai & $\begin{array}{c}0.11-0.22 \\
(0.2)\end{array}$ & $\begin{array}{c}29.6-33.7 \\
(31.8)\end{array}$ & $\begin{array}{c}43.8-47.9 \\
(46.1)\end{array}$ & $\begin{array}{l}23.2-26.6 \\
(24.8)\end{array}$ & $\begin{array}{c}78.9-125.9 \\
(98.8)\end{array}$ & $\begin{array}{c}45.6-84.4 \\
(76.1)\end{array}$ & $\begin{array}{c}471.1-655.2 \\
(553.7)\end{array}$ & $\begin{array}{c}0.6-1.3 \\
(1.0)\end{array}$ & $\begin{array}{l}3.1-9.0 \\
(6.1)\end{array}$ & \\
\hline & $\begin{array}{l}\text { several } \\
\text { locations }\end{array}$ & 0.40 & - & & 4.90 & - & & - & 0.32 & $3.6-26$ & [214] \\
\hline
\end{tabular}




\begin{tabular}{|c|c|c|c|c|c|c|c|c|c|c|c|}
\hline & Narora & $\begin{array}{l}0.6-4.6 \\
(2.4)\end{array}$ & $\begin{array}{c}6.41-153.5 \\
(31.8)\end{array}$ & - & $\begin{array}{l}2.0-46.0 \\
(21.8)\end{array}$ & - & $\begin{array}{c}3.9-21.5 \\
(8.1)\end{array}$ & $\begin{array}{c}3.3-35.5 \\
(21.7)\end{array}$ & - & - & [343] \\
\hline \multirow[t]{2}{*}{ India } & $\begin{array}{l}\text { several } \\
\text { locations }\end{array}$ & $(0.8)$ & - & - & 0.90 & - & - & - & $\begin{array}{l}0.23- \\
4.52\end{array}$ & $61-416$ & [214] \\
\hline & Fatehabad & - & $\begin{array}{c}10.8-37.0 \\
(21.8)\end{array}$ & $\begin{array}{c}0.04-23.5 \\
(10.4)\end{array}$ & $\begin{array}{l}7.5-148.2 \\
(54.4)\end{array}$ & $\begin{array}{c}71.5-146.7 \\
(106.0)\end{array}$ & $\begin{array}{c}0.1-9.7 \\
(6.5)\end{array}$ & - & - & - & [344] \\
\hline \multirow[t]{2}{*}{ Malaysia } & Kota & $(0.8)$ & - & - & - & - & 21.10 & 46.40 & - & - & [345] \\
\hline & $\begin{array}{l}\text { several } \\
\text { locations }\end{array}$ & $0.2-0.3$ & - & - & - & - & - & - & 0.43 & 11.00 & [214] \\
\hline \multirow[t]{2}{*}{ Japan } & $\begin{array}{l}\text { several } \\
\text { locations }\end{array}$ & $0.45^{\mathrm{T}}$ & & $39.0^{\mathrm{T}}$ & $29.0^{\mathrm{T}}$ & $99.0^{\mathrm{T}}$ & $64.0^{\mathrm{T}}$ & & & & [346] \\
\hline & Aomori & $\begin{array}{l}0.16-0.53 \\
(0.37)\end{array}$ & $\begin{array}{c}18.0-45.0 \\
(29.0)\end{array}$ & $\begin{array}{l}5.9-18.0 \\
(11.0)\end{array}$ & $\begin{array}{l}9.2-44.0 \\
(21.0)\end{array}$ & $\begin{array}{l}63.0-160.0 \\
(110.0)\end{array}$ & $\begin{array}{c}16.0-80.0 \\
(31.0)\end{array}$ & $\begin{array}{c}370.0-1500 \\
(700.0)\end{array}$ & $\begin{array}{l}0.72-1.4 \\
(1.0)\end{array}$ & $\begin{array}{c}6.7-34.0 \\
(12.0)\end{array}$ & [347] \\
\hline USA & $\begin{array}{l}\text { several } \\
\text { locations }\end{array}$ & $(0.3)$ & - & - & $(55.0)$ & - & - & - & - & $15-950$ & [214] \\
\hline \multirow{3}{*}{ Korea } & $\begin{array}{l}\text { several } \\
\text { locations }\end{array}$ & $(0.1)$ & - & - & (5.3) & - & - & - & $0.1-11$ & 0.78 & {$[262,348]$} \\
\hline & $\begin{array}{l}\text { several } \\
\text { locations }\end{array}$ & $\begin{array}{c}0.1-1.01 \\
(0.11)\end{array}$ & $\begin{array}{l}0.1-41.6 \\
\quad(4.7)\end{array}$ & - & $\begin{array}{c}0.01-66.4 \\
(4.8)\end{array}$ & $\begin{array}{c}0.1-96.7 \\
(4.5)\end{array}$ & - & - & - & - & [349] \\
\hline & $\begin{array}{l}\text { Four } \\
\text { mining } \\
\text { areas }\end{array}$ & $\begin{array}{c}0.001- \\
12.8 \\
(2.3)\end{array}$ & $\begin{array}{c}14.7-243.0 \\
(63.5)\end{array}$ & - & $\begin{array}{c}26.3-885.0 \\
(146.0)\end{array}$ & $\begin{array}{c}89.7-1600.0 \\
(393.0)\end{array}$ & - & - & - & $\begin{array}{l}2.8-704.0 \\
(64.4)\end{array}$ & [215] \\
\hline Pakistan & Shakargarh & $\begin{array}{c}1.0-78.9 \\
(35.0)\end{array}$ & - & $\begin{array}{c}60.0-99.7 \\
(85.8)\end{array}$ & $\begin{array}{c}113.8-2967 \\
(1065)\end{array}$ & - & $\begin{array}{c}13.8-89.8 \\
(37.8)\end{array}$ & - & - & - & [350] \\
\hline Thailand & Bangkok & $0.01-0.07$ & $0.7-3.0$ & $0.4-2.6$ & $0.2-1.4$ & $1.0-14.4$ & 0.1-1.9 & - & - & - & [351] \\
\hline
\end{tabular}


Table 2 Reported trace element concentrations ranges minimum-maximum (mean) $\mathrm{mg} / \mathrm{kg}$ in grain in different countries.

\begin{tabular}{|c|c|c|c|c|c|c|c|c|c|c|c|}
\hline Country & Locations & Cd & $\mathbf{C u}$ & $\mathbf{N i}$ & $\mathbf{P b}$ & Zn & $\mathrm{Cr}$ & Mn & Se & As & References \\
\hline \multirow{15}{*}{ China } & Wenling & $\begin{array}{c}0.1-0.5 \\
(0.1)\end{array}$ & $\begin{array}{c}0.7-5.8 \\
(3.1)\end{array}$ & $\begin{array}{c}0.05-1.7 \\
(0.2)\end{array}$ & - & $11.4-35.4$ & - & - & - & - & {$[3]$} \\
\hline & Shengzou & $\begin{array}{c}0.01-0.2 \\
(0.1)\end{array}$ & $\begin{array}{c}1.3-4.7 \\
(3.2)\end{array}$ & $\begin{array}{c}0.1-1.5 \\
(0.4)\end{array}$ & $\begin{array}{c}0.05-0.2 \\
(0.1)\end{array}$ & $\begin{array}{c}18.5-27.8 \\
(23.5)\end{array}$ & $\begin{array}{c}0.1-1.4 \\
(0.2)\end{array}$ & - & - & - & [352] \\
\hline & Zhejiang & $\begin{array}{l}0.1-0.112 \\
\quad(0.04)\end{array}$ & - & - & $\begin{array}{c}0.01-0.2 \\
(0.1)\end{array}$ & (2) & $(0.0)$ & - & - & $\begin{array}{c}0.1-0.3 \\
(0.1)\end{array}$ & [353] \\
\hline & Nanxu & $\begin{array}{c}0.01-0.10 \\
(0.01)\end{array}$ & $\begin{array}{l}1.1-4.2 \\
(2.5)\end{array}$ & $\begin{array}{c}0.02-1.4 \\
(0.1)\end{array}$ & - & $\begin{array}{c}9.45-22.0 \\
(14.3)\end{array}$ & - & - & - & - & [340] \\
\hline & Hunan & $\begin{array}{c}0.01-6.2 \\
(0.6)\end{array}$ & 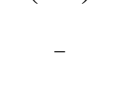 & - & $\begin{array}{l}1.2-4.8 \\
(0.05)\end{array}$ & - & - & - & - & $\begin{array}{c}0.01-1.0 \\
(0.1)\end{array}$ & {$[4]$} \\
\hline & Nanhu & - & $\begin{array}{c}2.9-8.9 \\
(5.5)\end{array}$ & - & $\begin{array}{c}0.1-0.5 \\
(0.2)\end{array}$ & $\begin{array}{c}21.1-27.1 \\
(23.2)\end{array}$ & $\begin{array}{c}0.2-0.4 \\
(0.2)\end{array}$ & - & - & - & \multirow{4}{*}[258]{} \\
\hline & Tongxiang & - & $\begin{array}{c}2.4-5.5 \\
(4.1)\end{array}$ & - & $\begin{array}{c}0.2-0.6 \\
(0.3)\end{array}$ & $\begin{array}{c}18.1-27.5 \\
(22.6)\end{array}$ & $\begin{array}{c}0.3-0.3 \\
(0.3)\end{array}$ & - & - & - & \\
\hline & Xiaoshan & - & $\begin{array}{c}2.8-6.7 \\
(4.7)\end{array}$ & - & $\begin{array}{c}0.2-0.5 \\
(0.3)\end{array}$ & $\begin{array}{c}17.7-25.2 \\
(21.3)\end{array}$ & $\begin{array}{c}0.1-0.3 \\
(0.2)\end{array}$ & - & - & - & \\
\hline & Shimen & $\begin{array}{c}0.01-0.7 \\
(0.3)\end{array}$ & - & $\begin{array}{c}0.3-1.2 \\
(0.7)\end{array}$ & $\begin{array}{c}0.01-0.03 \\
(0.02)\end{array}$ & (2- & $\begin{array}{c}0.03-0.11 \\
(0.1)\end{array}$ & - & - & $\begin{array}{c}0.3-1.2 \\
(0.5)\end{array}$ & \\
\hline & Fenghuang & $\begin{array}{c}0.01-2.1 \\
(0.3)\end{array}$ & - & $\begin{array}{c}0.1-1.4 \\
(0.5)\end{array}$ & $\begin{array}{c}0.003-0.02 \\
(0.01)\end{array}$ & - & $\begin{array}{l}0.05- \\
0.14 \\
(0.1)\end{array}$ & - & - & $\begin{array}{c}0.2-0.4 \\
(0.3)\end{array}$ & \multirow[t]{2}{*}{ [257] } \\
\hline & Xiangtan & $\begin{array}{c}0.01- \\
0.691(0.3)\end{array}$ & - & $\begin{array}{c}0.1-0.8 \\
(0.5)\end{array}$ & $\begin{array}{c}0.01-0.10 \\
(0.04)\end{array}$ & - & $\begin{array}{c}0.1-0.5 \\
(0.2)\end{array}$ & - & - & $\begin{array}{c}0.1-0.3 \\
(0.2)\end{array}$ & \\
\hline & Kaiyang & - & - & - & (n- & - & - & - & $\begin{array}{c}0.04-0.14 \\
(0.08)\end{array}$ & - & [354] \\
\hline & Yangtze River & - & - & - & - & - & - & - & $\begin{array}{c}0.02-0.04 \\
(0.03)\end{array}$ & - & [355] \\
\hline & Enshi & - & - & - & - & - & - & - & $\begin{array}{c}(0.08-9.7 \\
(2.73)\end{array}$ & - & [262] \\
\hline & Wanshan & - & - & - & & - & - & - & $\begin{array}{c}(0.02-0.7) \\
(0.1)\end{array}$ & - & [356] \\
\hline
\end{tabular}




\begin{tabular}{|c|c|c|c|c|c|c|c|c|c|c|c|}
\hline & Rugao & - & - & - & - & - & - & - & $\begin{array}{c}0.016-0.40 \\
(0.09)\end{array}$ & - & [357] \\
\hline \multirow{6}{*}{ India } & Narora & $\begin{array}{l}0.1-0.25 \\
(0.1)\end{array}$ & $\begin{array}{c}0.3-2.2 \\
(1.1)\end{array}$ & - & $(0.24)$ & - & $(0.03)$ & $(0.23)$ & - & - & [343] \\
\hline & Fatehabad & - & $\begin{array}{c}0.9-5.7 \\
(1.9)\end{array}$ & $\begin{array}{c}0.04-0.41 \\
(0.4)\end{array}$ & $\begin{array}{c}0.06-1.0 \\
(0.6)\end{array}$ & $\begin{array}{l}5.5-20.2 \\
(11.6)\end{array}$ & $\begin{array}{l}0.1-0.9 \\
(0.6)\end{array}$ & - & - & - & [344] \\
\hline & West Bengal & -- & $2.1-4.6$ & $0.13-1.1$ & - & $3.21-10.3$ & - & - & - & - & [358] \\
\hline & $\begin{array}{l}\text { Market } \\
\text { purchased }\end{array}$ & $\begin{array}{c}9.4-178.0 \\
(27.5)\end{array}$ & - & - & $\begin{array}{l}29-1529 \\
(173)\end{array}$ & - & - & - & - & - & [359] \\
\hline & Bengal delta & - & -- & & - & - & - & - & - & $0.07-0.31$ & [360] \\
\hline & Punjab & - & - & - & - & - & - & - & $4.83-8.0$ & - & [214] \\
\hline \multirow{4}{*}{ Bangladesh } & $\begin{array}{l}\text { Market } \\
\text { purchased }\end{array}$ & $\begin{array}{l}69-77 \\
(73.0)\end{array}$ & $\begin{array}{l}1.3-1.9 \\
(1.6)\end{array}$ & $\begin{array}{l}76-163 \\
(105)\end{array}$ & $5-28(19.0)$ & $\begin{array}{c}12.1-14.9 \\
(13.4)\end{array}$ & $\begin{array}{c}41-217 \\
(119)\end{array}$ & $\begin{array}{c}13.2- \\
16.0 \\
(14.7)\end{array}$ & - & - & [359] \\
\hline & $\begin{array}{l}\text { Market } \\
\text { purchased }\end{array}$ & $(0.1)$ & - & - & $(0.3)$ & - & - & - & - & $0.41-0.98$ & [214] \\
\hline & $\begin{array}{l}\text { Market } \\
\text { purchased }\end{array}$ & - & - & - & $(3.19)$ & - & - & - & - & $0.02-0.33$ & [214] \\
\hline & $\begin{array}{l}\text { Market } \\
\text { purchased }\end{array}$ & - & - & - & $(0.7)$ & - & - & & $0.07-0.16$ & - & [214] \\
\hline Thailand & Market purchase & $\begin{array}{l}8.2-16.0 \\
(13.4)\end{array}$ & 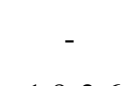 & -5 & $\begin{array}{c}23.1-68.1 \\
(37.0)\end{array}$ & - & - & - & $0.05-0.10$ & - & [361] \\
\hline \multirow{2}{*}{ Pakistan } & Market purchase & $\begin{array}{l}0.1-8.9 \\
(4.5)\end{array}$ & $\begin{array}{l}1.9-3.6 \\
(2.6)\end{array}$ & $\begin{array}{c}77-180 \\
(118)\end{array}$ & $\begin{array}{l}3-168 \\
(67.0)\end{array}$ & $\begin{array}{l}14.5-17.1 \\
(16.2)\end{array}$ & $\begin{array}{c}48-113 \\
(79.0)\end{array}$ & $\begin{array}{l}7.3-8.7 \\
(7.8)\end{array}$ & $0.05-0.25$ & $(0.15)$ & {$[359,361]$} \\
\hline & Shakargarh & $\begin{array}{c}0.2-1.6 \\
(0.9)\end{array}$ & - & $\begin{array}{c}38.6-52.6 \\
(46.3)\end{array}$ & $\begin{array}{c}38.6-55.9 \\
(45.7)\end{array}$ & - & $\begin{array}{l}4.6-12.2 \\
(7.0)\end{array}$ & - & - & - & {$[350]$} \\
\hline Australia & Market purchase & $\begin{array}{c}8.7-17.1 \\
(7.5)\end{array}$ & $\begin{array}{c}1.0-9.4 \\
(2.9)\end{array}$ & $\begin{array}{l}61-356 \\
(166)\end{array}$ & $\begin{array}{l}16-1248 \\
(375)\end{array}$ & $\begin{array}{c}10.9-24.5 \\
(17.1)\end{array}$ & $\begin{array}{r}15-465 \\
(144.0)\end{array}$ & $\begin{array}{c}9.2- \\
51.7 \\
(24.4)\end{array}$ & - & - & [359] \\
\hline Malaysia & Kota & $0.03-0.18$ & $0.3-0.4$ & - & - & $0.4-0.7$ & $0.2-1.3$ & $0.5-1.5$ & - & - & [345] \\
\hline Korea & $\begin{array}{l}\text { Four mining } \\
\text { areas }\end{array}$ & $\begin{array}{c}0.01-0.98 \\
(0.17)\end{array}$ & $\begin{array}{l}2.0-29.6 \\
(4.7)\end{array}$ & - & $\begin{array}{c}0.01-3.34 \\
(0.8)\end{array}$ & $\begin{array}{c}7.3-38.0 \\
(16.8)\end{array}$ & - & - & - & $\begin{array}{c}0.10-0.77 \\
(0.25)\end{array}$ & [215] \\
\hline \multirow{2}{*}{ Iran } & Several locations & $(0.64)$ & $(1.1)$ & $(0.76)$ & $(0.64)$ & $(28.6)$ & $(0.4)$ & - & - & $(0.05)$ & [362] \\
\hline & Ghaemshahr & - & - & $(1.0)$ & $(6.1)$ & - & (2.4) & - & - & $(0.94)$ & [363] \\
\hline USA & $\begin{array}{l}\text { Market } \\
\text { purchased }\end{array}$ & $(0.02)$ & - & - & 0.01-0.09 & - & - & - & $(0.02)$ & $0.2-0.7$ & [214] \\
\hline
\end{tabular}




\begin{tabular}{|c|c|c|c|c|c|c|c|c|c|c|c|}
\hline & $\begin{array}{l}\text { Market } \\
\text { purchased }\end{array}$ & - & - & - & - & - & - & - & $(0.32)$ & $0.2-0.34$ & {$[214,354]$} \\
\hline & $\begin{array}{l}\text { Market } \\
\text { purchased }\end{array}$ & $(0.05)$ & - & - & $(0.002)$ & - & - & - & $0.03-0.109$ & (1.8) & [214] \\
\hline Japan & & $\begin{array}{c}0.004-0.1 \\
(0.03)\end{array}$ & $\begin{array}{c}0.6-3.9 \\
(2.1)\end{array}$ & $\begin{array}{c}0.02-0.4 \\
(0.11)\end{array}$ & $\begin{array}{c}0.001-0.09 \\
(0.01)\end{array}$ & $\begin{array}{c}13.0-19.0 \\
(16.0)\end{array}$ & $\begin{array}{c}0.001- \\
0.05 \\
(0.01)\end{array}$ & $\begin{array}{c}5.4-18.0 \\
(9.7)\end{array}$ & $\begin{array}{c}0.001- \\
0.006 \\
(0.003)\end{array}$ & $\begin{array}{c}0.05-0.15 \\
(0.09)\end{array}$ & [347] \\
\hline
\end{tabular}


Table 3 Trace element content and translocation factor (TF) from paddy soil to different parts (roots, shoots, \& grains) of the rice plant.

\begin{tabular}{|c|c|c|c|c|c|c|c|c|c|}
\hline \multirow[b]{2}{*}{ Metal } & \multirow[b]{2}{*}{$\begin{array}{l}\text { Metal level } \\
\text { in soil } \mathrm{mg} / \mathrm{kg}\end{array}$} & \multirow[b]{2}{*}{$\begin{array}{c}\text { Metal level } \\
\text { in root } \mathrm{mg} / \mathrm{kg}\end{array}$} & \multirow[b]{2}{*}{$\begin{array}{c}\text { Metal level } \\
\text { in shoot } \mathrm{mg} / \mathrm{kg}\end{array}$} & \multirow[b]{2}{*}{$\begin{array}{l}\text { Metal level } \\
\text { in grains } \mathrm{mg} / \mathrm{kg}\end{array}$} & \multicolumn{5}{|c|}{$\begin{array}{l}\text { Metals translocation factor (TF) from paddy soil to rice plants } \\
\text { parts }\end{array}$} \\
\hline & & & & & $\begin{array}{c}\text { Soil to } \\
\text { root }\end{array}$ & $\begin{array}{c}\text { Root to } \\
\text { shoot }\end{array}$ & $\begin{array}{c}\text { Shoot to } \\
\text { grains }\end{array}$ & $\begin{array}{c}\text { Soil to } \\
\text { grain }\end{array}$ & References \\
\hline As & 5.42 & 22.77 & 0.68 & 0.06 & 4.2 & 0.03 & 0.09 & 0.011 & \multirow{3}{*}[364]{} \\
\hline $\mathrm{Cd}$ & 0.86 & 6.16 & 0.62 & 0.01 & 7.19 & 0.1 & 0.02 & 0.012 & \\
\hline $\mathrm{Cu}$ & 23.22 & 2.09 & 0.17 & 0.05 & 0.09 & 0.08 & 0.29 & 0.002 & \\
\hline $\mathrm{Pb}$ & 18.65 & 7.09 & 1.84 & 0.52 & 0.38 & 0.26 & 0.28 & 0.028 & \multirow{5}{*}{ [365] } \\
\hline $\mathrm{Cd}$ & 2.39 & 16.32 & 3.35 & 0.85 & 6.83 & 0.21 & 0.25 & 0.356 & \\
\hline $\mathrm{Cu}$ & 59.13 & 32.67 & 5.52 & 2.79 & 0.55 & 0.17 & 0.51 & 0.047 & \\
\hline $\mathrm{Pb}$ & 40.91 & 29.46 & 4.45 & 0.84 & 0.72 & 0.15 & 0.19 & 0.021 & \\
\hline $\mathrm{Zn}$ & 305.03 & 80.75 & 27.58 & 2.3 & 0.26 & 0.34 & 0.08 & 0.008 & \\
\hline $\mathrm{Cd}$ & 35.02 & 0.85 & 0.85 & 0.85 & - & - & 1.0 & 0.024 & \multirow{4}{*}{ [350] } \\
\hline $\mathrm{Pb}$ & 1,065 & - & 48.81 & 45.75 & - & - & 0.94 & 0.043 & \\
\hline $\mathrm{Cr}$ & 37.8 & - & 9.17 & 6.99 & - & - & 0.76 & 0.185 & \\
\hline $\mathrm{Co}$ & 747.2 & - & 71.58 & 49.89 & - & - & 0.7 & 0.067 & \\
\hline $\mathrm{Ni}$ & 85.84 & - & 54.5 & 46.34 & - & - & 0.85 & 0.539 & \multirow{6}{*}{ [260] } \\
\hline $\mathrm{Cd}$ & 0.58 & - & 1.59 & 0.48 & - & - & 0.29 & 0.001 & \\
\hline $\mathrm{Cu}$ & 20.4 & - & 0.3 & 0.24 & - & - & 0.8 & 0.012 & \\
\hline $\mathrm{Pb}$ & 27.9 & - & 0.07 & 0.02 & - & - & 0.29 & 0.001 & \\
\hline $\mathrm{Ni}$ & 20.4 & - & 0.08 & 0.09 & - & - & 1.13 & 0.004 & \\
\hline $\mathrm{Cd}$ & 0.17 & - & - & 0.01 & - & - & - & 0.059 & \\
\hline $\mathrm{Pb}$ & 29.6 & - & - & 0.05 & - & - & - & 0.002 & [366] \\
\hline $\mathrm{Se}$ & 11.46 & 11.82 & 1.35 & 1.88 & 0.96 & 6.28 & 0.71 & 6.09 & [151] \\
\hline $\mathrm{Cd}$ & 4.64 & - & - & 1.81 & - & - & - & 2.5 & [367] \\
\hline
\end{tabular}




\section{Supplementary information}

Comprehensive review of the basic chemical behaviours, sources, processes, and endpoints of trace element contamination in paddy soil-rice systems in rice-growing countries

Waqar Ali a, b, Kang Mao, Hua Zhang ${ }^{a^{*}}$, Muhammad Junaid ${ }^{\mathrm{c}}$, Nan Xu ${ }^{\mathrm{c}}$, Atta Rasool ${ }^{\mathrm{e}}$, Xinbin Feng ${ }^{\mathrm{a}}$ and Zhugen Yang ${ }^{\mathrm{d}}$

a State Key Laboratory of Environmental Geochemistry, Institute of Geochemistry, Chinese Academy of Sciences, Guiyang 550081, China.

${ }^{\mathbf{b}}$ University of Chinese Academy of Sciences, Beijing 100049, China.

${ }^{\mathbf{c}}$ Key Laboratory for Heavy Metal Pollution Control and Reutilization, School of Environment and Energy, Peking University Shenzhen Graduate School, Shenzhen 518055, China.

${ }^{\mathrm{d}}$ Cranfield Water Science Institute, Cranfield University, Cranfield, MK43 0AL, United Kingdom.

e Department of Environmental Sciences COMSATS University, Islamabad Vehari Campus, Vehari 61100. Pakistan.

\section{*Corresponding author}

Prof. Hua Zhang

Email: zhanghua@mail.gyig.ac.cn 


\section{Supplementary information}

Table S1 Compression of recent review papers about trace element contamination in soil-plant and rice system.

Table S2 Trace element arsenic (As), selenium (Se), cadmium (Cd), lead (Pb), Zinc ( $\mathrm{Zn}$ ), manganese $(\mathrm{Mn})$, and chromium $(\mathrm{Cr})$ chemical behaviuors in soil system and key transporters facilitate the uptake, transportation, and accumulations in soil-to-rice system.

Table S3 Comparison of different trace element polluted soil management/remediation methods. 
Table S3 Comparison of recent review papers about trace element contamination in soil-plant and rice system.

\begin{tabular}{|c|c|c|c|c|}
\hline Topics & Objectives & Gaps & Year & Reference \\
\hline $\begin{array}{l}\text { Heavy Metals in Contaminated Soils: } \\
\text { A Review of Sources, Chemistry, } \\
\text { Risks and Best Available Strategies } \\
\text { for Remediation }\end{array}$ & $\begin{array}{l}\text { Scattered literature is utilized to review the possible } \\
\text { sources of contamination, basic chemistry, and the } \\
\text { associated environmental and health risks of metals } \\
(\mathrm{Pb}, \mathrm{Cr}, \mathrm{As}, \mathrm{Zn}, \mathrm{Cd}, \mathrm{Cu}, \mathrm{Hg} \text {, and } \mathrm{Ni}) \text {, which can } \\
\text { provide insight into heavy metal speciation, } \\
\text { bioavailability, and hence the selection of appropriate } \\
\text { remedial options. }\end{array}$ & $\begin{array}{l}\text { The current status of trace elements } \\
\text { contamination in major rice-growing } \\
\text { countries and the translocation (metals } \\
\text { key transporters) mechanisms from soil- } \\
\text { to-paddy plants not reported }\end{array}$ & 2011 & [1] \\
\hline $\begin{array}{l}\text { A review of soil heavy metal pollution } \\
\text { from mines in China: Pollution and } \\
\text { health risk assessment }\end{array}$ & $\begin{array}{l}\text { The objectives of this research are 1) to evaluate the } \\
\text { soil heavy metal pollution levels of mines in China; } 2 \text { ) } \\
\text { to assess the health risks posed by these contaminated } \\
\text { soils; 3) and to propose recommendations for the } \\
\text { environmental management of mining areas in China. }\end{array}$ & $\begin{array}{l}\text { Explain on the national status of trace } \\
\text { element contamination in soil system but } \\
\text { the trace metals contamination status in } \\
\text { different countries and translocation } \\
\text { mechanisms in soil-to-plant not reported. }\end{array}$ & 2012 & [2] \\
\hline $\begin{array}{l}\text { Current status of heavy metal } \\
\text { contamination in Asia's rice } \\
\text { lands }\end{array}$ & $\begin{array}{l}\text { Provide an analytical summary extracted } \\
\text { from recent publications on heavy metal contamination } \\
\text { in Asia's agricultural lands and subsequent } \\
\text { accumulation in different parts of the rice plant }\end{array}$ & $\begin{array}{l}\text { The basic behaviors of trace elements (As, } \\
\mathrm{Se}, \mathrm{Cd}, \mathrm{Pb}, \mathrm{Zn}, \mathrm{Mn}, \mathrm{Ni} \text {, and } \mathrm{Cr} \text { ) in soil } \\
\text { system and translocation (metals key } \\
\text { transporters) mechanisms from soil to } \\
\text { paddy plants not reported. }\end{array}$ & 2013 & [3] \\
\hline $\begin{array}{l}\text { Role of phosphate fertilizers in heavy } \\
\text { metal uptake and detoxification of } \\
\text { toxic metals }\end{array}$ & $\begin{array}{l}\text { The main objective of this review is to assess the role } \\
\text { of phosphorus in fertilizers, their uptake along with } \\
\text { other elements and signaling during P starvation }\end{array}$ & $\begin{array}{l}\text { Trace elements behaviors, current status, } \\
\text { translocation, accumulation mechanisms, } \\
\text { graphical representation, and trace } \\
\text { elements management methods in the } \\
\text { soil-rice system not reported. }\end{array}$ & 2013 & [4] \\
\hline
\end{tabular}


Arsenic translocation in rice cultivation and its implication for human health

A critical review on effects, tolerance mechanisms and management of cadmium in vegetables

An Overview of Selenium Uptake, Metabolism, and Toxicity in Plants

The Journey of Arsenic from Soil to Grain in Rice

A critical review of selenium biogeochemical behavior in soil-plant system with an inference to human health
Explains possible mechanisms involved in As absorption that contaminate the rice plant through the soil and water and mentions studies that have been conducted to minimize the risk for human exposure

Highlight the Cd toxicity and tolerance in vegetables and the different management options to reduce $\mathrm{Cd}$ uptake and toxicity in vegetables

The detailed mechanism of Se metabolism inside the plants and designing effective Se phytoremediation and biofortification strategies.

Explain As translocation mechanisms from soil-torice system and factors affecting As availability at roots level.

Critically highlights Se speciation and bioavailability in soil, its soil-plant transfer, compartmentation, essentiality, toxicity, and detoxification in plants, keeping in view the Se-induced human health risks.
Focus on As metabolism inside rice plant, however, the current statues sources and translocation mechanisms of trace elements ( $\mathrm{Se}, \mathrm{Pb}, \mathrm{Cd}, \mathrm{Zn}, \mathrm{Mn}, \mathrm{Ni}$, and $\mathrm{Cr}$ ) in the soil-rice system not reported.

Only focus on $\mathrm{Cd}$ toxicity behavior mechanism and management in vegetables. However, the rest of the elements (As, Se, Pb, Zn, Mn, Ni, and 2017

$\mathrm{Cr}$ ) basic behaviors of trace elements in soil-plant, translocation mechanism, and management/remediation not reported.

Focus on Se metabolism inside the plant system, whereas, (As, Pb, Cd, Zn, Mn, Ni, and $\mathrm{Cr}$ ) the detail mechanisms behaviors 2017 sources and current status translocation mechanisms not reported.

Focus on As translocation mechanisms soil-to- rice system. In contrast, the current statues sources and translocation mechanisms of trace elements $(\mathrm{Se}, \mathrm{Pb}, \mathrm{Cd}$,

$\mathrm{Zn}, \mathrm{Mn}, \mathrm{Ni}$, and $\mathrm{Cr}$ ) in the soil-rice system not reported.

Focus on Se biogeochemical behavior in the soil-plant system, but the rest of the elements ( $\mathrm{As}, \mathrm{Pb}, \mathrm{Cd}, \mathrm{Zn}, \mathrm{Mn}, \mathrm{Ni}$, and

$\mathrm{Cr}$ ) basic behaviors of trace elements in 
Precise manner toxic elements regulation limits

A critical prospective analysis of the potential toxicity of trace element regulation limits in soils worldwide: Are they protective concerning health risk assessment? - A review

Metal(loid)s (As, $\mathrm{Hg}, \mathrm{Se}, \mathrm{Pb}$ and $\mathrm{Cd}$ ) in paddy soil: Bioavailability and potential risk to human health concerning soil in major countries and organizations around the globe to compare and critique them and applying health risk assessment caused by human exposure to the soil by investigating the scenario that soils have toxic elements levels equal to their maximum legislation limits.

Summarizes mobilization, translocation and speciation mechanism of these metal(loids) in the soil-plant continuum as well as available cost-effective remediation measures.

In this review, we amid systematically and comprehensively review and understand the basic behaviors of trace metals (As, $\mathrm{Se}, \mathrm{Cd}, \mathrm{Pb}, \mathrm{Zn}, \mathrm{Mn}, \mathrm{Ni}$ and $\mathrm{Cr}$ ) in the soil-system to assess sources, uptake,

A comprehensive review of the basic chemical behaviors, sources, process, and the fate of trace elements contamination in paddy soil-rice system of rice-growing countries translocation, accumulation mechanisms via different transporters like As (silicate $(\mathrm{Si})$, phosphate $(\mathrm{Pi})$ ), $\mathrm{Se}$ (sulfate (ST)), Cr (Pi or ST), Zn (AtZIP1or NRAMP), Mn (NRAMP5 or AtZIP1), Ni (NRAMP), and Cd (NRAMP5, OsIRT1, or osHMA2) in rice system., the status of trace elements contamination, and associated risk, in paddy soil-rice systems in rice-growing countries, and polluted soil management/remediation methods.
Trace elements behaviors, current status, translocation accumulation mechanisms of elements, graphical representation, and 2019

trace elements management methods in the soil-plant system not reported.

The $\mathrm{Zn}, \mathrm{Mn}, \mathrm{Ni}$ and $\mathrm{Cr}$ status, behaviors translocation mechanisms in paddy-soil 2019 rice system not reported. 
Table S4 Trace element arsenic (As), selenium (Se), cadmium (Cd), lead (Pb), Zinc (Zn), manganese (Mn), and chromium (Cr) chemical behaviour in soil system and key transporters facilitate the uptake, transportation, and accumulations in soil-to-rice system.

\section{Elements}

Chemical behaviors and occurrence

in soil system

Arsenic (As) has four oxidation states $(-3,0,+3, \&+5)$, which occurs in a different type of minerals such as $\mathrm{As}_{2} \mathrm{O}_{3}$. Two main species of As such as

As arsenate $((\mathrm{As}) \mathrm{V}))$ under oxidizing and arsenite (As(III)) dominant under reducing soil conditions. The $\mathrm{AsV}$ is dominant in the form of arsenate ion $\left(\mathrm{AsO}_{4}{ }^{3-}\right)$ different states such as arsenic acid $\left(\mathrm{H}_{3} \mathrm{AsO}_{4}\right)$, dihydrogen arsenate $\left(\mathrm{H}_{2} \mathrm{AsO}_{4}{ }^{-}\right)$, hydrogen arsenate $\left(\mathrm{HAsO}_{4}{ }^{-}\right)$, and arsenate ion $\left(\mathrm{AsO}_{4}{ }^{3}\right)$.

Selenium (Se) is a metalloid that shows chemical resemblance with Sulfur (S). The common valance states of Se are $(-2,0,+2,+4 \&+6)$, selenide $\left(\right.$ SeII $\left.{ }^{-}\right)$, selenium $\left(\mathrm{Se}^{\mathrm{o}}\right)$, thioselenate $\left(\mathrm{SSeO}_{3}{ }^{2-}\right)$, selenite (SeIV) and selenate (SeVI) respectively. In soil system selenate $\left(\mathrm{SeO}_{4}{ }^{2-}\right)$ and selenite $\left(\mathrm{SeO}_{3}{ }^{2-}\right)$ stable in soil for extended periods.

Cadmium (Cd) is poisonous, and non-essential elements in soils system occur in its compound as divalent ion $\mathrm{Cd}$ (II). Cd can form the inner-sphere complexes; at $\mathrm{pH}<6.5$, mainly bound with organic matter $(\mathrm{OM})$, while at $\mathrm{pH}>$ 6.5 to Fe-oxides In soil system. The complexes with OM or inorganic ligands, Furthermore, in soil system significant part of $\mathrm{Cd}$ bound with humic acids like cadmium carbonate $\left(\mathrm{CdCO}_{3}\right)$
Key transporters uptake and translocated trace

elements in soil-to rice system

References

As $(\mathrm{V})$ uses different phosphate transporter $(\mathrm{Pi})$ that belong to the PHT1 family because $\mathrm{P}$ is chemically like As(V). The As(III) uses silicon ( $\mathrm{Si})$ transporters like Lsi1 (aquaporin NIP2;1) and Lsi2 (an efflux carrier) due to its resemblance with $\mathrm{As}(\mathrm{III})$ and $\mathrm{Si}$

Selenite $(\mathrm{Se}(\mathrm{IV}))$ and selenate $(\mathrm{Se}(\mathrm{VI}))$ $[9,13-15]$ transported through phosphate and sulfate channels. The Se(VI) enters in the plasma membrane of plant root cells by sulfate transporters, and $\mathrm{Se}(\mathrm{IV})$ and $\mathrm{P}$ compete and enter into the plasma membrane of paddy plant root cell by $\mathrm{P}$ transporters.

ZIP transporter OsIRTs such as OsIRT1 plays a significant role in $\mathrm{Cd}$ uptake through roots in the paddy system while NRAMP5, OsHMA2, and osLCT1 play a crucial role in the transport of $\mathrm{Cd}$ in paddies roots shoots and grains respectively. 
Lead $(\mathrm{Pb})$ is a chalcophile metal that has a strong affinity with $\mathrm{S}$ combined with $\mathrm{S}$ other elements like ( $\mathrm{PbS}, \mathrm{PbSO} 4 \& \mathrm{PbCO} 3$ ) galena, lead sulfate, and lead carbonate respectively. In organic-rich soils, $\mathrm{Pb}$ bound with humic matter and Fe-oxides. Under reducing soil conditions, $\mathrm{PbS}$ precipitates and forms $\mathrm{Pb} 2+$ ions at oxidizing soil conditions.

Zinc $(\mathrm{Zn})$ under oxidizing conditions zinc sulfide $(\mathrm{ZnS})$ is a dominant species in the soil system. At higher soil $\mathrm{pH}$, reduced $\mathrm{Zn}$ adsorption and release of organically $\mathrm{Zn}$-complexed, and increased concentrations of chelating agents in the soil system. Also, at high $\mathrm{pH}, \mathrm{Zn}$ primarily precipitated as zinc hydroxide $\mathrm{Zn}(\mathrm{OH})_{2}$ and or zinc carbonate $\left(\mathrm{ZnCO}_{3}\right)$ in soil solution.

Manganese (Mn) naturally persist $(+2$, to +7$)$ oxidation states, and Mn (+2) primarily persists in rock-forming minerals. The Mn-complexes oxidized under atmospheric environments leads $\mathrm{Mn}$ released, transformed to oxides or hydroxides of secondary minerals, and accumulated in the soil system.

Nickel (Ni) In soil solution, Ni species usually occurs as aqueous nickelous ion Ni2+ form a complex with organic/inorganic ligands or allied with suspended mineral collides. Organic complexes the most dominant Ni species in soil solution instead of different inorganic species, i.e., $\mathrm{Ni}_{2}{ }^{+}, \mathrm{NiCO}_{3}, \mathrm{HiCO}_{3}{ }^{+}$, and $\mathrm{NiOH}^{+}$.

The $\mathrm{Cr}(\mathrm{VI})$ is the main form of $\mathrm{Cr}$ found at contaminated sites and depends on $\mathrm{pH}$ redox conditions $\mathrm{Cr}$ also occurs in (+III) oxidation state since $\mathrm{Cr}$ (IV) significantly dominant under oxidizing conditions. $\mathrm{The} \mathrm{Cr}$, such as chromate $\left(\mathrm{CrO}_{4}^{2-}\right)$ and dichromate $\left(\mathrm{Cr}_{2} \mathrm{O}_{7}{ }^{2-}\right)$, precipitated in presences of metal cations. The $\mathrm{CrO}_{4}{ }^{2-}$ and $\mathrm{Cr}_{2} \mathrm{O}_{7}{ }^{2-}$ adsorb on soil surfaces, particularly aluminum and ironoxides.
In paddy plants, root cells $\mathrm{H}+$ ATPase and $\mathrm{H}+$ drives can directly uptake $\mathrm{Pb}$. Furthermore, the transpiration process also a significant role to pull pushes $\mathrm{Pb} 2+$ from roots cell to shoots by xylem and shoots to leaves cells by the vascular flow.

ZIP family transporters such as AtZIP2 and NRAMP facilitate the uptake, transportation, and accumulations of $\mathrm{Zn}$ in the paddy soil-rice system.

ZIP family transporters AtZIP1, and NRAMP5 facilitates the uptake, transportation, and accumulations of Mn in paddy soil-rice systems.

NRAMP transporters facilitate the uptake, transportation, and accumulations of $\mathrm{Ni}$ in the $[25,26$, 29]. paddy soil-rice system.

$\mathrm{Cr}$ (III) and $\mathrm{Cr}$ (VI), the Pi and S transporters transportation, and accumulations of $\mathrm{Cr}$ in the paddy soil-rice systems. 
Table S5 Comparison of different trace elements polluted soil management/remediation methods.

\begin{tabular}{|c|c|c|c|c|c|c|c|}
\hline $\begin{array}{c}\text { Soil management/ } \\
\text { remediation } \\
\text { methods }\end{array}$ & Process involved & Significant advantages & limitations & Applicability & Acceptance & $\begin{array}{c}\text { Multi-element } \\
\text { sites }\end{array}$ & $\begin{array}{c}\text { Time } \\
\text { required }\end{array}$ \\
\hline \multicolumn{8}{|l|}{ Physical methods } \\
\hline $\begin{array}{l}\text { Soil replacement } \\
\text { method }\end{array}$ & $\begin{array}{c}\text { Excavating } \\
\text { contaminated soil } \\
\& \text { replacing by } \\
\text { non-contaminated } \\
\text { soil }\end{array}$ & $\begin{array}{c}\text { Effectively isolate toxic } \\
\text { elements from a } \\
\text { contaminated site \& } \\
\text { efficient for severely } \\
\text { polluted } \\
\text { soils }\end{array}$ & $\begin{array}{l}\text { Large in working } \\
\text { volume, very } \\
\text { costly, } \\
\text { production of } \\
\text { severe toxic } \\
\text { waste \& pose } \\
\text { severe effects on } \\
\text { soil } \\
\text { physicochemical } \\
\text { properties }\end{array}$ & $\begin{array}{c}\text { Small-scale } \\
\text { but long term }\end{array}$ & $\begin{array}{l}\text { Low: } \\
\text { limited to } \\
\text { severely } \\
\text { polluted } \\
\text { soils }\end{array}$ & Very effective & $\begin{array}{c}\text { Comparatively } \\
\text { less }\end{array}$ \\
\hline $\begin{array}{l}\text { Soil isolation } \\
\text { method }\end{array}$ & $\begin{array}{c}\text { Isolating } \\
\text { contaminated } \\
\text { soil from } \\
\text { uncontaminated } \\
\text { soil by subsurface } \\
\text { barriers }\end{array}$ & $\begin{array}{l}\text { Restrict off-site } \\
\text { transport of toxic } \\
\text { elements \& useful for } \\
\text { severely polluted soils }\end{array}$ & $\begin{array}{l}\text { Costly, still } \\
\text { needs further } \\
\text { engineering } \\
\text { measures, } \\
\text { effectiveness } \\
\text { varies with the } \\
\text { type of } \\
\text { subsurface } \\
\text { barrier }\end{array}$ & $\begin{array}{l}\text { Small-scale } \\
\& \text { short to } \\
\text { long-term }\end{array}$ & $\begin{array}{l}\text { Low: } \\
\text { limited to } \\
\text { severely } \\
\text { polluted } \\
\text { soils }\end{array}$ & Very effective & $\begin{array}{c}\text { Comparatively } \\
\text { less }\end{array}$ \\
\hline $\begin{array}{l}\text { Vitrification } \\
\text { method }\end{array}$ & $\begin{array}{c}\text { Reduction in toxic } \\
\text { elements } \\
\text { bioavailability by } \\
\text { forming various } \\
\text { material using } \\
\text { high temperature }\end{array}$ & $\begin{array}{c}\text { Easy application \& } \\
\text { applicable to a variety } \\
\text { of pollutants }\end{array}$ & $\begin{array}{l}\text { High cost due to } \\
\text { energy } \\
\text { requirement }\end{array}$ & $\begin{array}{c}\text { Small-scale } \\
\text { but long-term }\end{array}$ & Very low & Very effective & $\begin{array}{c}\text { Comparatively } \\
\text { less }\end{array}$ \\
\hline $\begin{array}{l}\text { Electrokinetic } \\
\text { method }\end{array}$ & $\begin{array}{l}\text { Removal of toxic } \\
\text { elements from the } \\
\text { soil by } \\
\text { electrophoresis, \& } \\
\text { or electro- } \\
\text { migration by } \\
\text { using DC-voltage }\end{array}$ & $\begin{array}{l}\text { Easy applicable, cost- } \\
\text { effective \& do not } \\
\text { affect physicochemical } \\
\text { properties of soil }\end{array}$ & $\begin{array}{l}\text { Requires soil } \\
\quad \text { with low } \\
\text { permeability \& } \\
\text { pH needs to be } \\
\text { controlled }\end{array}$ & $\begin{array}{c}\text { Small-scale } \\
\text { but long-term }\end{array}$ & Very low & Very effective & $\begin{array}{c}\text { Comparatively } \\
\text { less }\end{array}$ \\
\hline
\end{tabular}




\section{Chemical method}

Reduction in

elements mobility,

bioavailability by

using

amendment,

forming stable \&

immobile

complexes via

adsorption

Removal of toxic

elements from the

Soil washing

method

soil by extractants

\& forming stable

and mobile

complexes

\section{Phytoremediation}

toxic elements

uptake by plant

from soil \&

Phytovolatilization

release in vapor

form to the

atmosphere

Use of plants to reduce toxic

elements

Phytostabilization

bioavailability \& mobility in soils via sequestration in plant roots

$$
\text { Use of }
$$

Phytoextraction

plants to uptake,

translocate \&

concentrate toxic

$\begin{array}{ccc}\text { Fast and easily } & \text { Temporary } & \\ \text { applicable, cost- } & \text { solution \& } & \text { Small to } \\ \text { effective, \& covers a } & \text { continuous } & \text { medium } \\ \text { broad spectrum of } & \text { monitoring is } & \text { \& short-term } \\ \text { inorganic pollutants } & \text { required } & \end{array}$

Useful depends on the type of soil, elements

immobilizing

amendment

Lees to medium

Washing

extractant cause

Cost-effective, thoroughly clean-up toxic elements \& meets specific criteria

environmental

issue;

effectiveness

differs with soil

\& extractant type

Small-scale

but long-term

Medium

Useful

depends on the

type of soil,

elements \&

immobilizing

amendment

Lees to

medium

Restricted to

volatile toxic

elements, cause

$$
\text { other }
$$

environmenta

issues, no control

less disruptive

after metal

release to the

atmosphere

\section{A temporary}

solution,

Cos-effective \&

less disruptive

effectivenes

differs with soil,

plant \& element

medium scale

$\&$ short-term

Medium

Very low

Very long

type

Cos-effective, less disruptive,

$\&$ ecofriendly

\section{Effectiveness}

depends on plant

$$
\text { growing }
$$

conditions,

tolerance \&
Large-scale \& long-term
Mostly low except for some plants 


\begin{tabular}{|c|c|c|c|c|c|c|c|}
\hline & $\begin{array}{l}\text { elements from soil } \\
\text { to the aerial } \\
\text { harvestable } \\
\text { plant parts }\end{array}$ & & $\begin{array}{l}\text { bioavailability of } \\
\text { elements. Toxic } \\
\text { elements } \\
\text { accumulator } \\
\text { plants are } \\
\text { generally very } \\
\text { less in number }\end{array}$ & & & & \\
\hline Microbial remediation & $\begin{array}{c}\text { Use of } \\
\text { microorganisms } \\
\text { to increases plants } \\
\text { uptake } \\
\text { capacity }\end{array}$ & $\begin{array}{l}\text { Cost-effective, } \\
\text { increases plant growth, } \\
\text { elements uptake \& } \\
\text { translocation }\end{array}$ & $\begin{array}{l}\text { Depend on soil, } \\
\text { plant type of } \\
\text { element } \& \\
\text { microorganism }\end{array}$ & $\begin{array}{l}\text { Large-scale } \\
\& \text { long-term }\end{array}$ & High & $\begin{array}{l}\text { Low but more } \\
\text { effective than } \\
\text { phytoextraction }\end{array}$ & $\begin{array}{l}\text { Very long but } \\
<\text { than } \\
\text { phytoextraction }\end{array}$ \\
\hline
\end{tabular}

\section{References}

[1] R.A. Wuana, F.E. Okieimen, Heavy metals in contaminated soils: a review of sources, chemistry, risks and best available strategies for remediation, Isrn Ecology, 2011 (2011).

[2] Z. Li, Z. Ma, T.J. van der Kuijp, Z. Yuan, L. Huang, A review of soil heavy metal pollution from mines in China: pollution and health risk assessment, Science of the Total Environment, 468 (2014) 843-853.

[3] K. Arunakumara, B.C. Walpola, M.-H. Yoon, Current status of heavy metal contamination in Asia's rice lands, Reviews in Environmental Science and Bio/Technology, 12 (2013) 355-377.

[4] D. Gupta, S. Chatterjee, S. Datta, V. Veer, C. Walther, Role of phosphate fertilizers in heavy metal uptake and detoxification of toxic metals, Chemosphere, 108 (2014) 134-144.

[5] J.M. Bastías, T. Beldarrain, Arsenic translocation in rice cultivation and its implication for human health, Chilean journal of agricultural research, 76 (2016) 114-122.

[6] M. Rizwan, S. Ali, M. Adrees, M. Ibrahim, D.C. Tsang, M. Zia-ur-Rehman, Z.A. Zahir, J. Rinklebe, F.M. Tack, Y.S. Ok, A critical review on effects, tolerance mechanisms and management of cadmium in vegetables, Chemosphere, 182 (2017) 90-105.

[7] M. Gupta, S. Gupta, An overview of selenium uptake, metabolism, and toxicity in plants, Frontiers in Plant Science, 7 (2017) 2074. 
[8] S. Awasthi, R. Chauhan, S. Srivastava, R.D. Tripathi, The journey of arsenic from soil to grain in rice, Frontiers in Plant Science, 8 (2017) 1007.

[9] M. Shahid, N.K. Niazi, S. Khalid, B. Murtaza, I. Bibi, M.I. Rashid, A critical review of selenium biogeochemical behavior in soilplant system with an inference to human health, Environmental pollution, 234 (2018) 915-934.

[10] V. Antoniadis, S.M. Shaheen, E. Levizou, M. Shahid, N.K. Niazi, M. Vithanage, Y.S. Ok, N. Bolan, J. Rinklebe, A critical prospective analysis of the potential toxicity of trace element regulation limits in soils worldwide: Are they protective concerning health risk assessment?-A review, Environment international, 127 (2019) 819-847.

[11] R. Khanam, A. Kumar, A. Nayak, M. Shahid, R. Tripathi, S. Vijayakumar, D. Bhaduri, U. Kumar, S. Mohanty, P. Panneerselvam, Metal (loid) s (As, $\mathrm{Hg}, \mathrm{Se}, \mathrm{Pb}$ and $\mathrm{Cd}$ ) in paddy soil: Bioavailability and potential risk to human health, Science of the Total Environment, (2019) 134330.

[12] H.-J. Sun, B. Rathinasabapathi, B. Wu, J. Luo, L.-P. Pu, L.Q. Ma, Arsenic and selenium toxicity and their interactive effects in humans, Environment international, 69 (2014) 148-158.

[13] R. Chauhan, S. Awasthi, S. Srivastava, S. Dwivedi, E.A. Pilon-Smits, O.P. Dhankher, R.D. Tripathi, Understanding selenium metabolism in plants and its role as a beneficial element, Critical Reviews in Environmental Science and Technology, (2019) $1-22$.

[14] M. Schiavon, E.A. Pilon-Smits, Selenium biofortification and phytoremediation phytotechnologies: a review, Journal of environmental quality, 46 (2017) 10-19.

[15] L. Winkel, B. Vriens, G. Jones, L. Schneider, E. Pilon-Smits, G. Bañuelos, Selenium cycling across soil-plant-atmosphere interfaces: a critical review, Nutrients, 7 (2015) 4199-4239.

[16] K.N. Palansooriya, S.M. Shaheen, S.S. Chen, D.C. Tsang, Y. Hashimoto, D. Hou, N.S. Bolan, J. Rinklebe, Y.S. Ok, Soil amendments for immobilization of potentially toxic elements in contaminated soils: A critical review, Environment international, 134 (2020) 105046. 
[17] A. Sasaki, N. Yamaji, K. Yokosho, J.F. Ma, Nramp5 is a major transporter responsible for manganese and cadmium uptake in rice, The Plant Cell, 24 (2012) 2155-2167.

[18] P. Hooda, Trace elements in soils, John Wiley \& Sons, 2010.

[19] W.-Y. Song, J. Park, C. Eisenach, M. Maeshima, Y. Lee, E. Martinoia, ABC transporters and heavy metals, in: Plant ABC Transporters, Springer, 2014, pp. 1-17.

[20] S. Uraguchi, T. Fujiwara, Cadmium transport and tolerance in rice: perspectives for reducing grain cadmium accumulation, Rice, 5 (2012) 5 .

[21] J. Kumpiene, A. Lagerkvist, C. Maurice, Stabilization of $\mathrm{As}, \mathrm{Cr}, \mathrm{Cu}, \mathrm{Pb}$ and $\mathrm{Zn}$ in soil using amendments-a review, Waste management, 28 (2008) 215-225.

[22] R. Prasad, Y.S. Shivay, D. Kumar, Interactions of zinc with other nutrients in soils and plants-a Review, Indian Journal of Fertilisers, 12 (2016) 16-26.

[23] E.B.Ö. Güngör, M. Bekbölet, Zinc release by humic and fulvic acid as influenced by pH, complexation and DOC sorption, Geoderma, 159 (2010) 131-138.

[24] H. Ahmadi, Functional analysis of the metal hyperaccumulation and hypertolerance candidate genes NAS4, ZIP6, CAX1 and NRAMP3 in Arabidopsis halleri, in, Universität Bayreuth, 2017.

[25] Y. Ishimaru, R. Takahashi, K. Bashir, H. Shimo, T. Senoura, K. Sugimoto, K. Ono, M. Yano, S. Ishikawa, T. Arao, Characterizing the role of rice NRAMP5 in manganese, iron and cadmium transport, Scientific reports, 2 (2012) 286.

[26] M. Tiwari, D. Sharma, S. Dwivedi, M. Singh, R.D. Tripathi, P.K. Trivedi, Expression in A rabidopsis and cellular localization reveal involvement of rice NRAMP, OsNRAMP 1, in arsenic transport and tolerance, Plant, Cell \& Environment, 37 (2014) 140-152.

[27] Z.L. He, J. Shentu, X.E. Yang, Manganese and selenium, Trace elements in soils. London: Wiley, (2010) 481-496. 
[28] E. Pinto, A.A. Aguiar, I.M. Ferreira, Influence of soil chemistry and plant physiology in the phytoremediation of $\mathrm{Cu}, \mathrm{Mn}$, and $\mathrm{Zn}$, Critical reviews in plant sciences, 33 (2014) 351-373.

[29] Y. Ma, P.S. Hooda, Chromium, nickel and cobalt, Trace elements in soils, (2010) 461-480.

[30] J. Guertin, C.P. Avakian, J.A. Jacobs, Chromium (VI) handbook, CRC press, 2016.

[31] M. Dotaniya, J. Thakur, V. Meena, D. Jajoria, G. Rathor, Chromium pollution: a threat to environment-a review, Agricultural Reviews, 35 (2014).

[32] M. Shahid, S. Shamshad, M. Rafiq, S. Khalid, I. Bibi, N.K. Niazi, C. Dumat, M.I. Rashid, Chromium speciation, bioavailability, uptake, toxicity and detoxification in soil-plant system: A review, Chemosphere, 178 (2017) 513-533. 